EVILLE GORHAM Botany Dept, University of Toronto, Toronto, Ontario, Canada

Factors Influencing Supply of Major Ions to Inland Waters, with Special Reference to the Atmosphere

Geological Society of America Bulletin, y. 72 , p. $795-840,3$ figs., June 1961 


\section{Factors Influencing Supply of Major Ions to Inland Waters, with Special Reference to the Atmosphere}

Abstract: Sources of ion supply to natural inland waters include not only rocks and soils but also the atmosphere, whose significance has been underestimated. Atmospheric materials are transferred to surface waters by rain or snow, as dry fallout, or in gaseous form; the sources are the sea, land surfaces, volcanoes, products of air pollution, or organic debris. Ion supply by soil and rock weathering, which is usually more important than atmosplieric supply, involves solution, oxidation-reduction reactions, activity of hydrogen ions, and complex formation. Transfer from soils to waters

Résumé: Les lieux d'origine des ions fournis aux caux continentales naturelles comprennent non seulement les roches et les sols, mais aussi l'atmosphére, dont le rôle a été jusqu'à présent sousestimé. Les matériaux atmosphériques sont transportés jusqu'aux eaux de surface par la pluie et la neige, en pluie de poussières, ou à l'état gazeux; ils peuvent provenir de la mer, des surfaces terrestres, des volcans, des impuretés atmosphériques, et de débris organiques. L'apport d'ions par la décomposition des sols et des roches, qui est en général plus important que l'apport atmosphérique, nécessite la dissolution, des réactions d'oxidoréduction, l'activité d'ions-H et la chélation. Le

Resumen: Las fuentes suministradoras de iones de las aguas continentales naturales no comprenden solamente las rocas y suelos, sino también la atmósfera, cuya importancia ha sido subestimada hasta ahora. Los materiales atmosféricos son transferidos a las aguas superficiales por la lluvia o nieve, a través de la caída en seco o en forma gaseosa, siendo las fuentes el mar, las superficies, los volcanes, las poluciones del aire y los deshechos orgánicos. El suministro de iones por los suelos y por el intemperismo de las rocas, el cual es generalmente de más importancia que el suministro atmosférico, implica la disolución, las reacciones de reducción y oxidación, la actividad de iones de hidrógeno y la descomposición por reacciones

Zusammenfassung: $\mathrm{Zu}$ den Quellen, durch die den natürlichen Binnengewässern Ionen zugeführt werden, gehören nicht nur Gestcine und Erden, sondern auch die Atmosphäre, deren Bedeutung bisher unterschätzt worden ist. Atmosphärische is influenced by ion exchange and by modes of water percolation.

Five principal environmental factors-climate, geology, topography, biota, and time-interact to determine ionic concentration and composition of atmospheric precipitation, soil solutions, and lake and river waters, although the extent to which each applies is not well understood. Investigation of situations in which only a single factor varies effectively should do much to clarify the role of each in determining the ultimate composition of natural waters.

transfert depuis les sols jusqu'à l'eau est sous l'influence des échanges d'ions et du mode de percolation de l'eau.

Cinq facteurs principaux du milieu-climate, géologie, topographie, biota et temps-réagissent les uns sur les autres pour déterminer la concentration ionique et la composition des apports atmosphériques, des solutions des sols, et des eaux lacustres et fluviales, bien qu'on ne comprenne pas encore bien le rôle de chacun d'entre cux. L'étude de situations dans lesquelles un seul de ces facteurs varie effectivement devrait permettre d'élucider le rôle de chacun d'eux dans la composition ultime des eaux naturelles.

orgánicas. El traspaso desde los suelos a las aguas está influenciado por el intercambio de iones y por las modalidades de la percolación del agua.

Cinco factores principales del medio ambienteclima, geología, topografía, biota y tiempoactúan entre sí para determinar la concentración iónica, la composición de la precipitación atmosférica, de las soluciones en el suelo y de las aguas de los lagos y ríos, aunque no se sabe bien la importancia que tiene cada factor. La investigación de las situaciones en las que cada uno de los factores varía efectivamente, hará mucho para aclarar el papel que tiene cada uno en determinar la composición fundamental de las aguas naturales.

Stoffe werden den offenen Gewässern durch Regen oder Schnee, als trockener Niederschlag oder in Form von Gas zugeführt, wobei dic Quellen das Meer, Landoberflächen, Vulkane, Luftverunrcinigungen oder organische Überbleibsel sind. Ionenzu-

Gcological Society of America Bulletin, v. 72, p. 795-840, 3 figs., June 1961 
fuhr durch Verwitterung von Erden und Gesteinen, die gewöhnlich wichtiger ist als atmosphärische Zufuhr, schliesst Auflösung, Oxidation-Reduktionserscheinungen, Wirksamkeit von WasserstoffIonen und Chelation cin. Die Verlagerung von Erden in Gewässer wird durch Ionen-Austausch und durch die Art, wie das Wasser durchgesickert ist, beeinflusst.

Fünf prinzipielle Umgebungsfaktoren-Klima, Geologie, Topographie, Lebensraum und Zeitbeeinflussen sich gegenseitig und bestimmen die
Konzentration der Ionen und die Zusammensetzung von atmosphärischen Niederschlägen, mineralischen Lösungen, sowie die des Wassers von Seen und Flüssen. Es ist jedoch nicht ganz klar, bis zu welchem Grade jeder der Faktoren daran beteiligt ist. Die Untersuchung von Situationen, in denen nur einzelne Faktoren wirkungsvoll variieren, sollte viel dazu beitragen, die Rolle jedes cinzelnen bei der Bestimmung der tatsächlichen Zusammensetzung der natürlichen Gewässer zu klären.

\section{ӘВИЛЛ ГОРХЭМ}

\section{Факторы, Влияющие на Приток Основных Ионов во Внутренние Водоемы и Роль Атмосферы}

Peзrone: Источником нонов в водах внутренних водоемов являются не только горные породы и почвы, но и атмосфера, значение которой недооценивалось до сего времени. Атмосферное вещество попадает в поверхностные воды с дождем или снегом, в виде сухого осадка, тибо в газообразной форме. Источниюм этого материала являются моря, земная поверхность, загрязнение атмосферы, и органические остатки. Почва I выветривание горных пород обычно являются более важными источниками ионов ненели атмосфера. Этот процесс закпючается в растворении, ониспительно-восстаповительных реаниях, действи водородних ионов и в образовании комплексных соединений. Перенос понов из почвы в водоемы завнспт от иониого обмена и от условий циркуляяции води.

Климатпческе усповн, геопогеский характер местност, топографическе условия, бном, іг иремя являются пятью главными факторами, определяющими характер среды и обуславтиваюцими концентрацию ионов, состав атмосферных осадков, почвенных растворов, озерных и речных вод. Нунио признать, одиало, что пределы влияния гАжпого фактора па харантер среды не вполие лспн. Нсследование условий, при поторцх пзменяютея лишь единичне факторы, приведут к вылснению ропи каждого (рактора в отдельності. Это может бить пропведено путем потното анализа состава приропих вод.

\section{CONTENTS}

Introduction . . . . . . . . . . . . 797

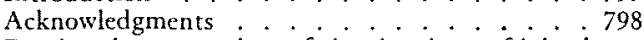
Previous interpretations of the chemistry of inland waters .......... 798

Climatic influences . . . . . . . . . . . . . 798

Geologic influences . . .

Chemistry of lakes in closed basins . . . . . 799

Concept of an average fresh water . . . . . 800

Basis of present interpretation . . . . . . 802

Sources and mechanisms of ion supply . . . . 802

General statement . . . . . . . . . 802

Illustrations of the importance of atmospheric supply ....... 802

Types of atmospheric supply . . . . . . . 803

Review of literature . . . . . . . . . 803

Rain . . . . . . . . . . 803

Dry fallout . . . . . . . . . 804

Snow . . . . . . . . . . . . . . 805

Gases . . . . . . . . . . . 805

Sources of atmospheric supply . . . . . . . 805

The sea . . . . . . . . 805
Soil. ............ 807

Volcanoes . 808

Air pollution. . . . . . . . . . . . 808

Organic matter. . . . . . . . . . . . . 809

Ion supply by soil and rock weathering . . 810

General discussion . . . . . . . . . . 810

Solution. . . . . . . . . . 810

Oxidation and reduction. . . . . . . . . 811

Action of hydrogen ions . . . . . . . . . 812

Complex formation . . . . . . . . 813

Significance of ion exchange . . . . . . . . . 813

Mode of water percolation . . . . . . . . 815

Environmental factors infuencing ionic composition 817

Climate . . . . . . . . 817

Geology. . . . . . . . . . . . . . . . . 820

Topography . . . . . . . . . . . . . . 823

Biology . . . . . . . . . . 826

Time . . . . . . . . . . . . 831 Interactions and conclusion $\ldots 833$ References cited . . . . . . . . . . . . . 833 
I.igure

1. Ratio of calcium to chloride in Swedish lake waters of varying elevation . . . . . . . 801

2. Weight ratio of chloride to sulfate in some Australian stream and river waters . . . .811

3. Chloride concentrations of lake waters at varying clevation in the Cairn Gorm region of Scotland ........... 818

Table

1. Ionic composition of the average fresh water of the world

2. Equivalent proportions of alkalies and alkaline earths in the bedrock and major river waters of Finland. 797 mparison of ionic composition in waters of arid and humid regions . . . . . . 799

4. Supply of ions by atmospheric precipitation, and the discharge of ions by river waters, in two districts of Finland . . . . . . 803

5. Comparison of average ionic concentrations in I year's atmospheric precipitation with average or minimum concentrations observed in lake or river waters . . . . . 804
6. Range of ionic concentration in European air masses during December 1957 and June 1958 . . . . 805

7. Composition of rime at Hallde in Norway and rain at Cape Bridgewater in South Ausof sea water . . . . . . . . . 806

8. Contents of organic matter (ignition loss), ash (ignition residue), silica, calcium, and potassium in 10 samples of Finnish snow 807

9. Percentage composition of dust from Green-

10. Ionic composition of rain at Knoxville, Tentralia, in comparison with the composition land ice . . . . . . . . . 808

\section{INTRODUCTION}

Although the fresh waters of the world are infinitely varied in their ionic composition, four cations-calcium, magnesium, sodium, and potassium-and three anions-bicarbonate, sulfate, and chloride-account for all but a small fraction of the total ionic concentration. The general proportions of these major cations and anions are given in Table 1, following computations of Clarke (1924, p. 119) and Conway (1942, p. 130).

It is of course most unlikely that ionic proportions in natural waters should reflect the make-up of the earth's crust, even with respect to the major ions mentioned. A brief consideration of Finnish river waters and rocks illustrates this point. Finnish bedrocks, like most igneous rocks, are very deficient in the carbonates, sulfates, and chlorides, which bulk so large in Finnish and other natural waters. A comparison of the relative proportions of alkalies and alkaline earths in the mainly granitic bedrock of Finland with their proportions in Finnish nessee . . . . . . . . . 809

11. Soluble materials in five samples of smoke solids from London chimneys . . . . . . 809

12. Ionic concentrations in the bottom waters of lakes and in the interstitial waters of their muds

13. Concentration and composition of cations in the water and adsorbed on the mud of Esthwaite Water . . . . . . . 815

14. Comparison of waters expressed from soil by pressure with ground waters and lake waters from the same areas. . . . . 816

15. Average composition of ground waters and

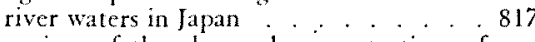

16. Comparison of the observed concentrations of chloride in Australian river waters with those calculated from rainfall analyses and river discharges

17. Comparison of ionic concentrations in Nova Scotian lake waters draining granites, mixed quartzites and slates, and Carboniferous strata . . . . . . . 821

18. Composition of Bohemian waters draining various gcological substrata . . . . 822

19. Analyses of Swedish ground waters on different substrata. . . . . . . . . . . . . 823

20. Water analyses from a seepage and a drainage pond in Epping Forest near London, England . . . . . . . . . . 824

21. Ionic proportions in Cheshire meres and Lake District rain 825

22. Consumption of mineral elements by vegetation, compared with amounts supplied in precipitation and carried by rivers . . . 827

23. Analyses of inflow and surface waters from Malham Tarn in Yorkshire, and analyses from pools on the adjacent raised bog . . 829 river waters (Viro, 1953, p. 15) indicates marked differences in cations (Table 2). The proportion of calcium in these Finnish river waters is nearly half as much again as in the rocks, while potassium in the waters is only about half the proportion found in the rocks. The Finnish river waters are also proportionately richer in magnesium and poorer in sodium than is the igneous bedrock. It thus

Table 1. Ionic Composition of the Average Fresh WATER OF THE WORLD

(Conway, 1942)

Total ionic concentration $2.35 \mathrm{~m}$ equiv. 1

\begin{tabular}{cc}
\hline Cations & m equiv. $\%$ \\
$\mathrm{Ca}$ & 64 \\
$\mathrm{Mg}$ & 17 \\
$\mathrm{Na}$ & 16 \\
$\mathrm{~K}$ & 3 \\
$\mathrm{Anions}$ & \\
$\mathrm{HCO}_{3}$ & 73 \\
$\mathrm{SO}_{4}$ & 16 \\
$\mathrm{Cl}$ & 10 \\
\hline
\end{tabular}


appears that the alkaline earths calcium and magnesium are dissolved from the soils of Finland to a greater extent than are the alkalies sodium and potassium, although in general one might expect the opposite relationship (Polynov, 1951). In these calculations no account has been taken of the ions supplied by rain, but data are available for two of the major Finnish rivers (Table 4), and the cation proportions of river water from which the rain contribution has been subtracted are also given in Table 2 . The conclusions remain unchanged, and it seems likely that most of the easily soluble alkalies have been leached from Finnish soils, allowing alkaline earths to pre-

Table 2. Equivalent Proportions of Alkalies and Alkaline Earths in the Bedrock and Major River Waters of Finland

(Calculated from Viro, 1953)

\begin{tabular}{lcccc}
\hline \hline & $\mathrm{Ca}$ & $\mathrm{Mg}$ & $\mathrm{Na}$ & $\mathrm{K}$ \\
\hline & m equiv. \%o of total alkalies \\
& \multicolumn{5}{c}{ plus alkaline eartis } \\
Bedrock & 32 & 22 & 26 & 20 \\
Five rivers & 45 & 27 & 19 & 9 \\
$\begin{array}{l}\text { Two rivers minus } \\
\text { rain contribution }\end{array}$ & 41 & 28 & 21 & 11 \\
\hline
\end{tabular}

dominate. It would be interesting to know how general this phenomenon is among inland waters on substrata of igneous origin.

\section{ACKNOWLEDGMENTS}

This review was begun at the Freshwater Biological Association laboratory, Ambleside, England, and it is a pleasure to thank my friend and former colleague John Mackereth for his unfailing kindness in allowing me to call upon his great knowledge of water chemistry. The manuscript has been read most carefully by Dr. D. A. Livingstone of Duke University and Mr. W. H. Durum of the U. S. Geological Survey, whose many suggestions for improvement place me greatly in their debt. I am also grateful to $\mathrm{Mr}$. W. B. Langbein of the U. S. Geological Survey for allowing me to read his important forthcoming paper on the salinity and hydrology of closed lakes, and to M. André Berg for informing me of his studies on water chemistry in the Belgian Congo. Dr. P. E. Cloud, Jr., has provided much helpful criticism of both material and presentation.

\section{PREVIOUS INTERPRETATIONS OF THE CHEMISTRY OF INLAND WATERS}

\section{Climatic Influences}

Despite wide variations in the chemistry of lake and river waters, a number of attempts have been made to establish general rules governing their composition. Clarke (1924, p. 93) early pointed out that, in more humid and fertile regions where vegetation is abundant, bicarbonate is commonly the dominant anion in river waters, whereas sulfate and chloride commonly predominate in the more concentrated river waters of arid and unproductive arcas. Table 3 compares the Hudson River in New York, draining moist and fertile areas, with the Rio Grande in New Mexico, draining arid regions (Clarke, 1924, p. 76 and 87). Bicarbonate is by far the most abundant anion in the Hudson water, while in the concentrated water of the Rio Grande it is outweighed by the sum of sulfate and chloride. Among the cations calcium predominates strongly in the Hudson water, while in the Rio Grande sodium is nearly as important. Under humid tropical conditions surface waters are very poor in dissolved salts but are also characterized by high proportions of silica. An analysis for the extremely dilute water of the Essequibo River in British Guiana (Clarke, 1924 , p. 95) is included in Table 3. Since the waters are brown and rich in organic matter, this river probably drains tropical podzols rather than lateritic soils (see Richards, 1941).

\section{Geologic Infuences}

Clarke (1924, p. 94) also remarked that, although climate is of major importance, local geological variation may greatly affect the character of rivers, especially near their sources. In large rivers such variations are evened out by the intermixing of tributaries, which "tends to produce an average composition which may be called that of a normal water."

The influence of geology was treated by Clarke mainly in its local aspects. Its more general significance has been considered by Conway (1942, p. 134), who examined the way in which concentrations and proportions of major ions change in relation to increases in the total salinity of river waters, using analyses compiled by Clarke.

According to Conway, waters of a salinity less than $50 \mathrm{ppm}$ represent drainage from

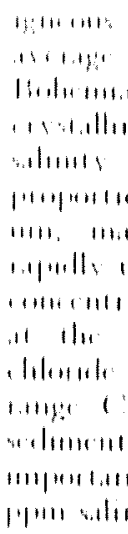

mintolsu' whill anl fellath of Alatiange |rowilily jolltilum.

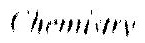

I.the wa 14116) 14 fitulataily itmerallas |11, (1)1011) (1116lit) ti latein d.

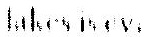

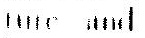
lintil 4 lin a) 131.4011 linke, and (1ing 11

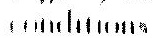
lim|ly l'tilil 
unncous and metamorphic rocks, since their average proportions agree well with those of Bohemian rivers known to flow through crystalline rocks only. Up to this level of salinity the major ions rise more or less in proportion to salinity. Above this level, calcium, magnesium, and bicarbonate increase rapidly until they reach more or less constant concentrations at about $200 \mathrm{ppm}$ total salinity; at the same time sodium, potassium, and chloride show relatively little change. In this range Conway believes that drainage from sedimentary rocks becomes more and more important as salinity rises. Above about 200 $\mathrm{ppm}$ salinity, sodium, potassium, and chloride
Thus annual temperatures higher than $40^{\circ} \mathrm{F}$ would theoretically permit development of a closed lake where precipitation equals 26 inches, whereas precipitation greater than 39 inches in an area of $60^{\circ} \mathrm{F}$ mean annual temperature would prevent such development. Langbein points out that closed lakes do not occur as widely as the above limits allow, since these presuppose absence of tributaries whose inflow would cause overflow from the lake. Moreover, near the theoretical climatic boundary, annual fluctuations in precipitation would lead to lakes being closed one year and open another, so that they would not be recognized as true closed lakes. These two factors therefore re-

Table 3. Comparison of Ionic Composirion in Waters of Amid and Humid Regions

(Data from Clarke, 1924)

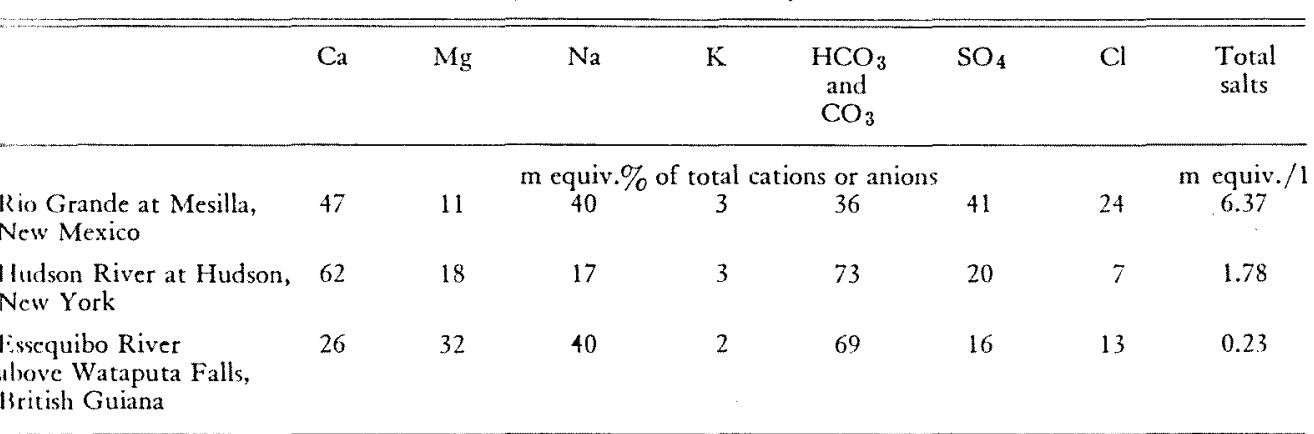

undergo a second rapid rise in concentration, while calcium, magnesium, and bicarbonate remain constant; this is interpreted as due to drainage from arid saline soils or salt beds, and possibly (although improbably) to large-scale pollution.

\section{Chemistry of Lakes in Closed Basins}

Lake waters in closed drainage basins without outlets to the ocean owe their high salinity primarily to climatic aridity. The median concentration appears to be in the vicinity of 10,000 ppm (Hutchinson, 1957, p. 565). According to Langbein (In press) the universal fictor determining the existence of closed lakes is evaporation, which varies with temperaIure and precipitation. The climatological limits for such lakes should be set by an excess of precipitation over evaporation from the lake, and the following values (from Langbein's lig. 3) are given for the bounding climatic conditions:

linity

Temperature $\left({ }^{\circ} \mathrm{F}\right) \quad 40 \quad 50 \quad 60$

Precipitation (inches) $26 \quad 32 \quad 39$ strict the distribution of closed lakes to regions where evaporation is appreciably in excess of precipitation.

Langbein also remarks that most closed lakes are far from saturated with respect to one or more of the common salts in natural waters, suggesting that accumulation must be offset by some form of wastage, as for example by occasional overflow or by deflation or burial of salts by sediment following a period of desiccation. He further suggests that the salts dissolved in a closed lake will generally reach equilibrium under a stable climate, but will fluctuate over long periods as the balance between input and loss alters. Equilibrium salinity is shown to depend not only upon climate but also upon the shape of the basin.

Clarke (1924, p. 180) and Hutchinson (1957, p. 566) set forth the changes to be cxpected in ionic proportions as a normal fresh water is concentrated by evaporation in a closed basin. First, the relatively insoluble carbonates of the alkaline carths will precipitate, followed by more soluble calcium sulfate. 
Then sodium carbonate and sulfate will precipitate, and later magnesium sulfate and sodium chloride, leaving the extremely soluble chlorides of the alkaline earths. The theoretical sequence is thus from carbonate to sulfatechloride to chloride waters. However, if the waters are initially low in alkaline earths, these may be almost wholly precipitated in the early phase of concentration, preventing any abundance of alkaline earth chlorides later. Even gypsum deposition may not be significant if calcium is scarce and becomes eliminated in the precipitation of calcium carbonate. In a similar fashion, should there be sufficient calcium to precipitate all the sulfate, no sodium sulfate will be deposited during subsequent concentration. In this way the initial proportions of ions play a major part in determining the sequence of salt deposition during evaporation, and the theoretical sequence will be observed seldom, if at all. It should also be remembered that the solubility of a given salt is not the same in the presence of other salts as in distilled water ( $c f$. Hem, 1959, p. 74, 78, 81, 103).

Hutchinson (1957, p. 565) considers two examples of the changes taking place during evaporation of normal river waters, where salt beds and saline springs presumably are not important sources of ions. In the Lahontan basin and adjoining regions of western North America the most dilute waters are strongly dominated by carbonates, but where evaporation is more advanced the proportion of carbonate declines, that of sulfate increases slightly, and the proportion of chloride increases markedly. Finally, the most concentrated waters are greatly enriched in sodium and chloride, which become the most abundant ions by far, whereas sulfate makes up only a very small proportion of total anions. Sume lakes of Indian Tibet, whose initial stage is likewise one of strong carbonate dominance, develop marked sulfate dominance and carbonate impoverishment in the phases of greatest concentration. Hutchinson suggests that this is because calcium was scarce initially and little was left for sulfate precipitation following the stage of carbonate deposition.

Anomalous types of concentrated waters may arise where the geological situation is unusual and modifies climatic influences. For example, where rocks are particularly rich in alkalies and poor in alkaline earths, waters may be greatly enriched in sodium, bicarbonate, and carbonate ions, as are those of Moses and Soap lakes in the State of Washington, U.S.A. (Hutchinson, 1957, p. 568) and the streams of Mount Meru, Tanganyika (Sturdy, Calton, and Milne, 1933).

Closed lakes whose salts are derived from primary weathering of igneous rocks may differ chemically from those whose waters leach sedimentary strata rich in salts of various kinds, often of oceanic origin. Waters draining sedimentary rocks may exhibit a great variety of ionic proportions, as shown in the wide range of data compiled by Clarke (1924).

Yet another type of saline lake with salts of marine origin is exemplified by Sambhar Lake in northern India (Holland and Christie, 1909). Its ions apparently derive from continued aerial transport of sea salt inland from the Rann of Cutch by winds. Lake Corangamite in Australia appears to be similar (W. G. Anderson, 1945).

\section{Concept of an Average Fresh Water}

The average fresh water of the world has been set up recently as a standard whose ionic proportions would gradually be approached by all waters if sufficient time were allowed, through the operation of ion-exchange processes between waters and the soils and rocks through which they percolate (Rodhe, 1949; Hutchinson, 1957, p. 556). This doctrine is even more extreme than the monoclimax theories of plant ecology and soil science, which assert that in time all plant communities and soils should approximate norms determined solely by the climatic factor. Recent work suggests that such idealized situations are far from real, and that the complexity of both vegetation and soil reflects continual interaction of several partially independent ecosystem factors (Jenny, 1941; Major, 1951; Crocker, 1952; see also Billings, 1952). A similar interaction is surely responsible for the wide range of variation in the ionic composition of natural waters. Some examination of the lakes of eastern Sweden will show this to be true even of the area where the hypothesis of an ideal "standard composition" originated (Rodhe, 1949; $c f$. Eriksson, 1955, p. 249).

In the Swedish districts of Dalarna and Uppland, Lohammar (1938) analyzed a great many lake waters, and his data show that the average ionic proportions of 21 Uppland lakes closely resemble those of the average fresh water of the world (Rodhe, 1949). There is in these Uppland and Dalarna lakes an inverse relation between total salt concentration and
$|1++|$

$111+11$

$\mid, \ldots h$

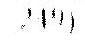

11,1

(1)!n!

finwlit

1111

liske

livin

i111/4h

Irollin.

llic 1

Huraty

llin 11

Hinlin

sin!

al senil

\|llis|l

blinentit

haten:

ilinlar

Ale 11

敖11411

"linaly:

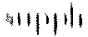

atiil 11

(1) क्या।

at! 111

(1) 114 
U.S.A. ams of alton

from

differ

leach

kinds,

sedi-

ety of

range

I salts

mbhar

hristie,

con-

from

ranga

W. G.

Id has

whose

oe ap-

c were

change

Is and

Rodhe,

pctrine

climax

which

es and

rmined

rk sug-

if from

vege-

tion of

factors

52; see

tion is

varia-

waters.

eastern

of the

andard

49; cf.

ha and

a great

that the

d lakes

e fresh

tre is in

inverse

ton and height above sea level (Gorham, 1955a, p. 142), altributed by the present author to greater leaching at higher altitudes. Eriksson (1955, p. 249) gives a much more likely explanation, that the relationship is due mainly to a marked concentration of salts by evaporation in the lowlands, where precipitation is much less than in the uplands. However, in discussing these lake waters further Eriksson adheres to Rodhe's hypothesis of uniform ionic proportions and lowest ratios (commonly less than 1) come from the very peculiar Dalarna seepage lakes on eskers. In these, calcium accounts for a much sinaller, and potassium a much larger proportion of total cations than in other Swedish lake waters. Troedsson (1955, p. 179) records similar differences in cation balance between waters seeping into lysimeters (underground instruments for measuring percolation), or expressed from the soil by pressure, and the

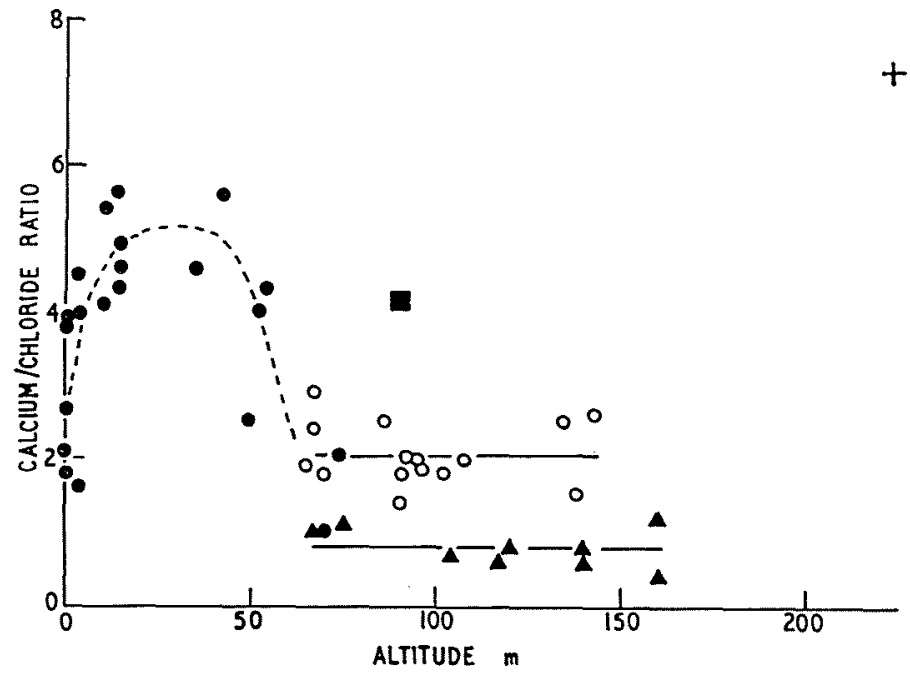

Figure 1. Ratio of calcium to chloride in Swedish lake waters of varying elevation. Solid circles-Uppland; open circles-Dalarna lakes on glacial till; solid triangles-Dalarna lakes on eskers; solid square-average for lakes on Dalälven sediments; cross-average for lakes on Siljan limestone

implies that the most significant factor controlling them is probably the composition of the precipitation, which remains unchanged throughout the upper parts of the soil where the ion-adsorbing colloids are in quasi-equilibrium with percolating rain water.

Such a view obscures the very real influence of soils and topography upon water chemistry, illustrated by the relation between calcium/chloride ratios and altitude of East Swedish lakes. In Figure 1 cvaporation effects are excluded by calculating the change in calcium, the major cation in these waters and largely supplied from the soil, in proportion to the change in chloride, which is known to be supplied almost wholly from the atmosphere and to be little affected by biological uptake or soil fixation. As might be expected, the calcium/chloride ratio is highest (7.3) in lakes of the Siljan limestone area. In contrast, the common type of lake and ground water in this general area.

Among other Dalarna lakes there is a clear distinction between those on Dalälven river sediments and those on glacial till. The former exhibit calcium/chloride ratios averaging 4.2 and are both absolutely and proportionately richer in calcium, the source being presumably Siljan limestone drift brought down in late glacial times. The lakes on till show ratios of about 2.1 , not greatly different from those of recent Swedish rain, and therefore suggesting that these lakes receive little calcium from soil leaching. In this group of lakes the constancy of the ratio at different altitudes favors Eriksson's hypothesis that an increase in the precipitation/evaporation ratio is chiefly responsible for the decline of total salt concentration with increasing elevation.

The Uppland lakes show most interesting 
variation in calcium/chloride ratio. The waters highest above sea level have low ratios, similar to those of Dalarna waters on till at the same or greater elevations. At lower levels the ratio rises to about 5 , presumably through solution of lime from calcareous clays and marls deposited during the marine submergence of this part of Sweden at the end of the ice age (Lundqvist, 1935, p. 293). Very near sea level distinctly lower ratios (in some cases less than 2) are again observed. These low ratios are due to a marked rise in the chloride concentrations of these waters, accompanied by a similar rise in sodium and magnesium. Marine influence is evident, but there seems little likelihood that differences in sea-spray supply are responsible, since neighboring lakes exhibit very different ratios. Because the lakes concerned are very near sea level, it seems reasonable to suppose that leaching has not yet eliminated the effects of marine submergence.

Such large variations in calcium/chloride ratio, even within the Uppland group of lakes, indicate the profound influence of topographical, geological, and historical factors upon the chemistry of waters in this region. Such effects can be obscured, however, by statistical treatment suggesting an ideal or "standard" composition resembling that of the average fresh water of the world.

\section{BASIS OF PRESENT INTERPRETATION}

If all fresh waters are not tending toward an ideal "standard composition," the factors operating to bring about and maintain differences in their ionic make-up must be examined. Five partially independent factors qualify for investigation: climate, geology, topography, biota, and time. It is evident that these factors are to some degree interdependent, and all may interact to condition the concentration and composition of any given body of water. Therefore, in order to demonstrate the effects of any factor, it is desirable to select (as far as possible) special cases in which that factor is of paramount importance and the others have little effect. Such instances are probably rare, and have been seldom sought, so that it will also be necessary to examine situations where factors interact to some extent. First, however, the sources and mechanisms of ion supply to natural waters may be considered, for knowledge of the processes through which environmental factors act may aid in the understanding of their effects.

\section{SOURCES AND MECHANISMS OF ION SUPPLY}

\section{General Statement}

It has been generally and quite correctly supposed that the main source of ions in fresh waters is the soil, weathered chiefly through attack by carbonic acid. However, it has become increasingly evident that a large part of the salts found in more dilute lake and stream waters, and even in some salt lakes of arid regiens, may come from the atmosphere.

\section{Illustrations of the Importance of Atmospheric Supply}

In the English Lake District many small lakes on volcanic rocks contain water with less than $0.2 \mathrm{~m}$ equiv. $/ 1$ of total salts, to which rain probably contributes almost the whole of the chloride, sulfate, sodium, and potassium. More than 80 per cent of the magnesium and more than half the calcium in these lakes also appear to be supplied by rain; the remainder of these two ions is supplied as bicarbonates by soil weathering (Gorham, 1958a, p. 173). Even in the most concentrated waters of the area, which range up to as much as $5 \mathrm{~m}$ equiv. $/ 1$ and drain sedimentary rocks, almost all the chloride and sodium probably comes from the rain, together with roughly half the sulfate and about 20 per cent of potassium and magnesium. Calcium and bicarbonate, which strongly dominate the cations and anions of these richer waters, are supplied almost wholly by the soils and rocks, in many cases limestone.

In Finland too a good deal of the material carried by rivers probably comes from atmospheric precipitation. Using data from the quarterly appendices to the journal Tellus, the atmospheric supply of ions in rain and snow may be calculated over a full year 1956-1957 at Kuopio and Jyväskylä, and compared with the quantities removed (per unit area) by the river systems Vuoksi and Kymijoki (Viro, 1953, p. 27), within whose drainage basins the two precipitation stations lie (Table 4). Such a comparison, despite inadequate precipitation data, shows the significance of the atmosphere as a source of ions. In these rivers the air appears to supply about 20 per cent of the sodium, 10-20 per cent of the potassium, about 10 per cent of the magnesium, 20-40 per cent of the calcium, $30-50$ per cent of the chloride, and 50-70 per cent of the sulfate. In reality almost all the chloride prcbably comes from the atmosphere, since the rocks
,

It

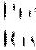

in

Iis

1

(1)

111

1

ilit

1

111

W

$10 \mathrm{H}$

(in

i)

,

II,

1,11

111

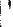

11.1

(i)

$1 ! 16$

II" 
are very deficient in it, and the present method al alculation greatly underestimates not only chloride but also probably other ions from precipitation. The discrepancy may well be Alic to the fact that vegetation captures drifting salt and dust particles from the air during diy woather, which are subsequently washed oll and into the soils and streams during rainy priods. Eriksson (1955, p. 245; 1960, p. 80) has suggested this explanation to account for a similar discrepancy between chloride disarage and precipitation in Sweden, while region; in some cases major-ion content in the rain is actually higher. Data for all these areas are included in Table 5.

Another indication of the importance of atmospheric ion supply, even to large continental river systems, is given by Alekin and Brazhnikova (1957), although they admit their data from the USSR give an exaggerated idea of its significance, owing to recycling of windblown salts from the soil during dry weather. (Cf. also Hutton and Leslie, 1958, p. 504.)

Concerning saline waters in arid regions, the

Table 4. Supply of Ions by Atmospheric Precipltation, and the Discharge of Ions by River Waters, in Two Districts of Finland

I'ecipitation data from Kuopio and Jyväskylä cover the period July 1956 to June 1957. In the former case March 1958 was substituted for March 1957, when some analyses were lacking; precipitation was very low in both these Marih samples.

\begin{tabular}{|c|c|c|c|c|c|c|}
\hline & $\mathrm{Ca}$ & $\mathrm{Mg}$ & $\mathrm{Na}$ & $\mathrm{K}$ & $\mathrm{SO}_{4}$ & $\mathrm{Cl}$ \\
\hline & \multicolumn{6}{|c|}{$\mathrm{kg} / \mathrm{ha} / \mathrm{yr}$} \\
\hline Irecipitation, Kuopio & 2.7 & 0.4 & 1.0 & 0.6 & 9.3 & 1.5 \\
\hline Kiver discharge, Vuoksi & 12.2 & 3.9 & 6.0 & 5.4 & 17.7 & 4.9 \\
\hline Precipitation, Jyväskylä & 4.2 & 0.4 & 1.4 & 0.9 & 11.0 & 3.2 \\
\hline \multirow[t]{2}{*}{ River discharge, Kymijoki } & 10.6 & 3.6 & 5.6 & 4.1 & 15.5 & 6.4 \\
\hline & \multicolumn{6}{|c|}{ precipitation as $\%$ river discharge } \\
\hline Kunpio/Vuoksi & 22 & 10 & 17 & 11 & 53 & 31 \\
\hline Iyviskylä/Kymijoki & 40 & 11 & 25 & 22 & 71 & 50 \\
\hline
\end{tabular}

Tamm (1953, p. 88) and Madgwick and ()vington (1959, p. 17) provide data on rain composition, in the open and under trees, that support such a view. It would apply cspecially in dry but well-forested areas.

Data from Swedish lakes (Lohammar, 1938) and rain stations (quarterly appendices to Tellus) show that minimal concentrations of mijor ions in the lake waters are close to avcrage levels in precipitation, even when cvaporative concentration of the latter is disregarded. Analyses of Wisconsin lake waters (se Hutchinson, 1957, Table 67, p. 551) give a similar picture of minimal concentrations near lhose reported for precipitation from the same general region by Junge and Werby (1958). 'The last-named authors' analyses of precipilation in Newfoundland are also closely similar Io the averages for analyses by Gorham (1957b, p. 14) of lake waters on granite in Nova Scotia. llarrison's (1934, p. 15) analyses of rainfall at (icorgetown, British Guiana, are likewise not greatly different from analyses cited by Clarke $(1924$, p. 95$)$ for river waters from the same data of Holland and Christic (1909) and V. G. Anderson (1945) indicate that aerial salt supply may sometimes be of great significance.

Eriksson (1960, p. 72) has attempted a balance shect for supply of elements (S, Cl, $\mathrm{Na}, \mathrm{Mg}, \mathrm{Ca}, \mathrm{K}$ ) to the ocean, in which two estimates are given for air-borne material.

\section{Types of Atmospheric Supply}

Review of literature. Although atmospheric supply of ions to lake and river waters has seldom been considered of great importance, the mineral materials in the atmosphere that are precipitated from it have long engaged attention (see Eriksson, 1952), and a great deal of information has been gathered about them (reviewed by Junge, 1958). The concentrations of the major ions present in air and in precipitation are being intensively studied in Europe (see quarterly appendices to Tellus), and some work is being done in the United States. (See Junge, 1956; Junge and Werby, 1958.)

Rain. Much of the atmospheric salt reaching lake and river waters is washed down by 
rain. In wet areas such as the English Lake District the amounts supplied to the ground daily are much more closely related to rainfall than to any other variable (Gorham, 1958a, p. 150); and, in Australia and Hawaii, Twomey (1955) and Squires and Twomey (1957) have demonstrated the influence of precipitation in removing salt particles from the air. portance of dry fallout, this time from more arid continental areas, may be seen by comparing the concentrations of salts in precipitation falling upon inland areas in the central U.S.A. (Junge and Werby, 1958) and the U.S.S.R. (Alekin and Brazhnikova, 1957). Junge and Werby, using collectors open only during intervals of precipitation, report concen-

Table 5. Comparison of Average Ionic Concentrations in 1 Year's Athospheric Precipitation with Average or Minimum Concentrations Observed in Lake or River Waters (ppm)

\begin{tabular}{|c|c|c|c|c|c|c|c|}
\hline & & $\mathrm{Ca}$ & $\mathrm{Mg}$ & $\mathrm{Na}$ & $\mathrm{K}$ & $\mathrm{SO}_{4}$ & $\mathrm{Cl}$ \\
\hline Precipitation & Single station, Newfoundland & 0.8 & n.d. & 5.2 & 0.3 & 2.2 & 8.9 \\
\hline Lake water & $\begin{array}{l}\text { Winter average, waters on } \\
\text { granite, Nova Scotia }\end{array}$ & 1.0 & 0.5 & 5.2 & 0.4 & 5.9 & 7.7 \\
\hline Precipitation & Single station, Wisconsin & 1.2 & n.d. & 0.5 & 0.2 & 2.9 & 0.2 \\
\hline Precipitation & Single station, Minnesota & 1.0 & n.d. & 0.2 & 0.2 & 1.4 & 0.1 \\
\hline Lake water & $\begin{array}{l}\text { Minimum concentration } \\
\text { observed, Wisconsin }\end{array}$ & 0.1 & $<0.5$ & 0.1 & 0.3 & 0.8 & 0.1 \\
\hline Precipitation & $\begin{array}{l}\text { Single station, Öjebyn, } \\
\text { northern Sweden }\end{array}$ & 1.2 & 0.2 & 0.4 & 0.3 & 2.5 & 0.7 \\
\hline Lake water & $\begin{array}{l}\text { Minimum concentration } \\
\text { observed, northern Sweden }\end{array}$ & 1.1 & 0.5 & 0.6 & $<0.2$ & 0.2 & 0.4 \\
\hline Precipitation & $\begin{array}{l}\text { Single station, Ultuna, } \\
\text { central Sweden }\end{array}$ & 0.6 & 0.1 & 0.3 & 0.2 & 2.6 & 0.5 \\
\hline Lake water & $\begin{array}{l}\text { Minimum concentration } \\
\text { observed, Dalarna }\end{array}$ & 0.6 & 0.3 & 0.3 & trace & 0.2 & 1.3 \\
\hline Lake water & $\begin{array}{l}\text { Minimum concentration } \\
\text { observed, Uppland }\end{array}$ & 1.7 & 0.6 & 1.0 & $<0.4$ & 2.4 & 1.7 \\
\hline Precipitation & $\begin{array}{l}\text { Three-year average, } \\
\text { Georgetown, British Guiana }\end{array}$ & 0.8 & 0.3 & 1.5 & 0.2 & 1.3 & 2.9 \\
\hline River water & Demerara River & 0.3 & 1.9 & 8.0 & 1.2 & 0.8 & 7.5 \\
\hline River water & Essequibo River & 1.2 & 0.9 & 2.1 & 0.2 & 1.7 & 1.0 \\
\hline
\end{tabular}

Dry fallout. In less humid regions dry fallout may be appreciable; in Massachusetts, for example, Junge and Gustafson (1957, p. 164) found about 25 per cent more chloride in continuously open containers than in containers open only during precipitation periods. In Japan Hanya (1951) calculated that rainfall carries down only about 14 per cent of the chloride in river waters, while 41 per cent is due to dry fallout. As mentioned earlier, Eriksson $(1955 ; 1960)$ has suggested that vegetation is an important collector of dry salt particles from the air of Sweden, where the amount of river-borne chloride greatly exceeds that supplicd by precipitation and cannot be accounted for by rock weathering or other sources. Yet another indication of the im- trations much below those recorded by the Soviet workers, who apparently left their collectors open continuously. Perhaps the most impressive examples of dry fallout are the salt lakes of the Sambhar region in India (Holland and Christie, 1909), where very high salinities appear explicable by aerial transport of sea salt during the dry season from the Rann of Cutch, more than $500 \mathrm{~km}$ away. Eriksson (1958, p. 169) has recently dealt with the general question of sea-salt transport into arid regions.

To illustrate the concentrations of ions found in air, Table 6 presents the range of values given in the 1958 issues of Tellus for 72 European stations during the month of December 1957 and 69 stations during the month 
more

com-

cipita-

entral

d the

1957).

1 only

oncen-

ION

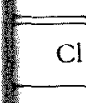

8.9

7.7

0.2

0.1

0.1

0.7

0.4

0.5

1.3 of June 1958. The air samples are very pure inclecel at some stations, while large amounts of ions are present at others, especially near the sal or near industrial centers.

Snow. In high latitudes snow is an important fraction of precipitation, and this may lessen the amount of salt carried down from the air. Total ash, sulfur, and nitrogen are much lower in snow than in winter rain at Kentville, Nova Scotia, suggesting a lesser efficiency of snowllakes in removing materials from the air (IIcrman and Gorham, 1957). Denisov and winds lead to wave formation on the sea surface, and the larger waves tend to break and produce foam patches containing a multitude of minute bubbles. Such foam patches may also be formed by waves breaking on the sea shore (Boyce, 1951). When the bubbles surface and burst, they shoot up tiny jets which break into droplets at their tips. Many of the droplets are sufficiently small to be swept up into the air, and may evaporate there to form salt particles, which are capable of acting as nuclei for cloud and raindrop condensation (Woodcock et al.,

Table 6. Rance of Ionic Concentration in European Air Masses

During December 1957 and June 1958

In $\mu \mathrm{g} / \mathrm{m}^{3}$ or $\mathrm{kg} / \mathrm{km}^{3}$

\begin{tabular}{|c|c|c|c|c|c|c|c|}
\hline & $\begin{array}{l}\text { No. of } \\
\text { stations }\end{array}$ & $S$ & $\mathrm{Cl}$ & $\mathrm{Na}$ & $\mathrm{K}$ & $\mathrm{Mg}$ & $\mathrm{Ca}$ \\
\hline \multicolumn{8}{|c|}{ 1)e. 1957} \\
\hline Min. & \multirow{2}{*}{72} & 0 & 0.6 & 0 & 0 & 0 & 0 \\
\hline Max. & & 67 & 240 & 212 & 24.6 & 20 & 31 \\
\hline \multicolumn{8}{|c|}{ lune 1958} \\
\hline Min. & \multirow{2}{*}{69} & 0 & 0 & 0.2 & 0.3 & 0 & 0 \\
\hline Max. & & 41 & 89 & 56 & 6.0 & 10 & 33 \\
\hline
\end{tabular}

Bugaiov (1956) report much smaller differences from the U.S.S.R., where, however, the precipitation is unusually rich in salts, probably owing to dustfall. Even here "dry" snow has a lower mineral content than "wet" snow.

Gases. All the major anions in natural waters may be cycled through the atmosphere, or at least supplied to it, partly in a gaseous state. Bicarbonate of course derives from carbon dioxide, and sulfur may be present in air either as sulfur dioxide or hydrogen sulfide. Under certain circumstances (Gorham, 1958a, p. 166,1958 d) chlorine too may be released to the atmosphere as a gas, hydrogen chloride, which soon dissolves in cloud and rain droplets. Junge (1956, p. 137) has claimed that the air may carry as much sulfur and chlorine in the gas phase as in solid or dissolved particulate form.

\section{Sources of Atmospheric Supply}

The sea. Chloride, sulfate, sodium, and magnesium are supplied to the air in large amounts from sea spray. The way in which sea silt enters the atmosphere is thought to be as follows, according to the views of Woodcock (1953, p. 364; see also Owens, 1940). High
1953), or of being captured by raindrops. Apparently about 99 per cent of the mass of natural sea spray is found in the so-called "giant particles" above $0.8 \mu$ radius (Junge, 1957 , p. 31), and these are large enough to be swept from the air in considerable amounts by vegetation (Sugawara, Oana, and Koyama, 1949; Boyce, 1954, p. 41; Eriksson, 1955, p. $245 ; 1958$, p. 152). According to Sugawara (1951, p. 14) the chloride content of streams may vary under different types of vegetation cover because of variation in the effectiveness of the plant cover in filtering salt from the air.

The actual presence of sea-salt particles in the air, even far inland, has been shown frequently, for example by Woodcock (1953), Twomey (1954), and Junge (1954; 1956). Their connection with cloud and raindrop formation has been suggested by Woodcock (1952; Woodcock and Blanchard, 1955). Twomey (1959, p. 241), however, claims that the main source of cloud nuclei is probably the dry land surface; Went (1960) speculates that volatile plant products may also serve in this capacity, and Bowen (1956) suggests meteoritic dust for the same role.

Many studies showing a marked decline of 
rain, river, and lake water chlorides inland point to sea spray as a very important source of this ion in maritime areas. Studies on the ratios of sodium and magnesium to chloride in rain from the English Lake District (Gorham, $1955 \mathrm{~b}, \mathrm{p} .232$ ), and on the influence of winds from the sea on rain chlorides (Gorham, 1958a, p. 156), provide further evidence on this question. Perhaps the purest example of marine salt precipitation is the Norwegian rime analyzed by Köhler (1923), for which data are given in Table 7. Rain at Cape Bridgewater in South Australia (Hutton and Leslie, can supply excess chloride. Cauer (1949, p. $229 ; 1951$, p. 1131) has suggested that sea-salt particles may be oxidized by atmospheric ozone, releasing free chlorine gas which is eventually transformed to hydrochloric acid, and substituting bicarbonate for chloride in combination with the sodium ions. This process is not likely to be quantitatively important (Eriksson, 1960, p. 77), although it has been argued recently by Oddie (1959). A greater likelihood of decomposition would appear to arise from the mixing of sea-salt particles with sulfuric-acid droplets from

Table 7. Composition of Rime at Hallde in Norway and Rain at Cape Bridgewater in South Australia, in Comparison with the Composition of Sea Water Chloride taken as 100 in each case; calculations by weight

\begin{tabular}{lllllll}
\hline \hline & $\mathrm{Ca}$ & $\mathrm{Mg}$ & $\mathrm{Na}$ & $\mathrm{K}$ & $\mathrm{SO}$ & $\mathrm{Cl}$ \\
\hline Sea water & 2.1 & 6.7 & 56 & 2.0 & 14 & $(100)$ \\
Hallde rime & 2.4 & 7.6 & 56 & n.d. & 16 & $(100)$ \\
Cape Bridgewater rain & 6.4 & 7.3 & 57 & 2.2 & $9.6^{*}$ & $(100)$ \\
\hline
\end{tabular}

* The sulfate methods cmployed for these Australian analyses were said to be gencrally unsatisfactory for low amounts. If sulfate is calculated by difference (sum of cations minus sum of chloride and bicarbonate), the value in this table would be 14 , identical with that of sea water.

1958, p. 500) likewise appears to contain rather pure sea water, except for the addition of considerable calcium and bicarbonate from calcareous sand dunes (Hutton, 1958, p. 289). Analyses of this rain are also given in Table 7. Even far at sea, however, particulate matter in the atmosphere may be very different from sea salt in ionic composition. Lodge, Macdonald, and Vihman (1960) report that sulfate exceeds chloride by weight in air samples taken about midway between San Francisco and Honolulu.

If the "giant particles" were the only source of sodium and chloride in atmospheric precipitation, the two ions should be present in the same proportions as in sea water. However, the chloride/sodium ratio frequently departs far from the sea-water value of 1.8 , sometimes with chloride and sometimes with sodium in marked excess (Rossby and Egnér, 1955; Gorham, 1958 a, p. 161). Soil dust probably contributes excess sodium (Kalle, 1953-1954; Junge and Werby, 1958, p. 423), which Hutton (1958) has shown to be correlated with excess calcium and potassium in South Australian rain. Volcanoes (Bottini, 1939) and particularly industrial areas (Gorham, 1958a, p. 161; 1958d) centers of air pollution or other sources. Upon abstraction of moisture by freezing or evaporation, gaseous hydrochloric acid could be released from the mixed droplets, thus altering the balance of chloride and sodium in precipitation. The droplets would exhibit an excess of sodium, but the hydrochloric acid would eventually enrich precipitation elsewhere in chloride. Some experimental and observational evidence for such a process has been adduced by Gorham (1958a, p. 165), and it has also been suggested independently on theoretical grounds by Eriksson (1958, p. 167; 1960, p. 77).

Erikksson (1958, p. 154) has further suggested that a similar process of chloride release may take place through the absorption and subsequent oxidation of sulfur dioxide by arid soils rich in sodium chloride. However, arid soils are commonly quite alkaline, and would probably neutralize any acid as soon as produced. Such release would be more likely from strongly acid forest soils, which may be rich in sulfuric acid (Gorham, 1958b; 1958f) and often become very dry at the surface in summer.

According to Robbins, Cadle, and Eckhardt (1959) the release of hydrogen chloride from anlinitil

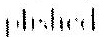

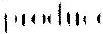

Simp: ahin $x+1,+1$ (11,1) It lilinith Inthl $\left.\right|^{\circ}$ linil: liv li) intilat 1.1.11) $11+1111 \%$

(imill * 11illilet lilin wil 1100t +allin linte) lin 1116! the whene lawn mintente (10101901 |iclanil minclei loliever C vel, Si emilit III जit hlopyes Inomil live: anclit il 4t) (10) mights alllal: ( antwa) indel I animliet (x) 11 tis Ir:land, liyalines

"llie: liand Jecilly

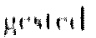
yuation folmaty linlines" 111 tive Ilalin IIII llinl il Intaliा id $111 \mathrm{y}+1$ 
soxlium chloride particles might also be accomplished through interaction with nitric acid proluced by hydrolysis of nitrogen dioxide.

Sugawara, Oana, and Koyama (1949, see also Koyama and Sugawara, 1953) have suggested that evaporation of sea salt in the air may lead to a separation of hygroscopic choride particles, easily washed out by rain, from less hygroscopic and consequently more long-lived sulfate and carbonate particles. This hypothesis deserves more investigation, parlicularly by experiment. It has been discussed recently by Eriksson (1960, p. 76), who doubts its importance.

Conway (1942, p. 156) has postulated the sea as a source of more sulfate than that contributed by sea spray. To account for a large deficiency in the balance sheet for sulfur in river waters, he invoked diffusion of volatile sulfur compounds (presumably hydrogen sullidc) from the muds of the continental shelf into the sea, and thence to the atmosphere, where they are oxidized to sulfate and washed lown by rain. Such sulfate might provide condensation nuclei for the sea mist causing atmospheric opacity at Valentia in western Ircland. Wright (1940) found that the mist nuclei there are definitely hygroscopic; he believed them to be particles of sea salt. Howcver, Simpson (1941b) showed that the nuclei could not be sea salt, for almost no reduction in air opacity occurred as relative humidity dropped below 70 per cent. Because this is about the point at which sea salt nuclei crystallize, a sudden reduction in opacity should occur if sea-salt droplets are responsible. Simpson (1941a, p. 120) concluded that nitrous acid might be involved, since industrial sources of sulfate were not present in the area, but if Conway's hypothesis is correct the sea floor could be an alternative source of sulfate. Yet another nonindustrial source might be the cxtensive water-logged peat deposits of western Ireland, from which some release of gaseous hydrogen sulfide is most likely.

The possibility that hydrogen sulfide is released from the sea floor has been discussed recently by Eriksson (1960, p. 74), who sugrested that very small concentrations and gradients, undetectable by present analytical iechniques, could produce enough sulfate to balance the sulfur not otherwise accounted for in river waters. He also remarked that tidal llats may be a source of hydrogen sulfide, and that it could be released in large amounts by protein breakdown in the metabolic turnover of organic matter near the sea surface.
The recent data of Junge and Werby (1958, p. 422) have been used to both deny and assert the importance of the sea as a source of hydrogen sulfide, which eventually oxidizes to sulfate in the atmosphere. Junge and Werby (1958, p. 423) presented a map of the concentration of excess sulfate in precipitation over the United States, for which the values were calculated by subtracting from observed sulfate the amount expected from the observed chloride concentrations if the two ions were present in the same proportions as in sea water.

Table 8. Contents of Organic Matter (Ignition Loss), Ash (Ignition Residue), Silica, Calcium, and Potassium in 10 Samples of Finnish SNow $(\mathrm{ppm})$

\begin{tabular}{|c|c|c|c|c|}
\hline $\begin{array}{l}\text { Ignition } \\
\text { loss }\end{array}$ & $\begin{array}{l}\text { Ignition } \\
\text { residue }\end{array}$ & $\mathrm{SiO}_{2}$ & $\mathrm{Ca}$ & $\mathrm{K}$ \\
\hline 1.58 & 1.24 & 0.14 & trace & 0.10 \\
\hline 2.36 & 1.26 & 0.23 & 0.03 & 0.09 \\
\hline 3.89 & 2.48 & 0.27 & 0.07 & 0.19 \\
\hline 3.28 & 2.14 & 0.36 & 0.13 & 0.11 \\
\hline 4.36 & 5.88 & 0.42 & 0.25 & 0.63 \\
\hline 5.85 & 6.60 & 0.45 & 0.34 & 0.83 \\
\hline 8.17 & 10.02 & 0.52 & 0.79 & 0.51 \\
\hline 5.90 & 9.15 & 0.62 & 0.30 & 0.74 \\
\hline 4.00 & 4.21 & 0.66 & 0.41 & 0.20 \\
\hline 8.70 & 12.73 & 1.44 & 1.14 & 0.93 \\
\hline
\end{tabular}

This map showed greater excess sulfate concentrations inland, which was taken to indicate that the source is the land surface. Eriksson (1960, p. 91) used the same data to calculate the excess sulfate supplied per unit area of land surface and indicated a tendency for the amounts to be higher near the sea. The suggested coastal gradients are, however, not very clear. Since both ion concentration in precipitation and ion supply to the ground are strongly influenced by the amount of precipitation and other environmental factors, it is difficult to place much reliance on either of the above interpretations.

Soil. In addition to being recycled in the dry state through the atmosphere, dust from the ground makes an important contribution of salts to rain and snow in many cases. It seems to be a major source of calcium and potassium in precipitation, as has been emphasized by Kalle (1953-1954), Junge and Werby (1958, p. 421-423), Durov and Fedorova (see Chilingar, 1956), Hutton (1958), and Hutton and Leslie (1958, p. 504). Analyses of snow by Viro (1953, p. 36) exhibit distinct correlations between calcium, potassium, and the silica con- 
tent of the snow (Table 8), which might be taken to suggest the importance of soil dust. Since there is also a marked correlation with organic matter, such an interpretation remains doubtful. The presence of appreciable amounts of calcareous dust in the air near limestone regions has also been inferred from $\mathrm{pH}$ values and calcium concentrations in the rain of Sweden (Barrett and Brodin, 1955, p. 256) and western Ireland (Gorham, 1957a).

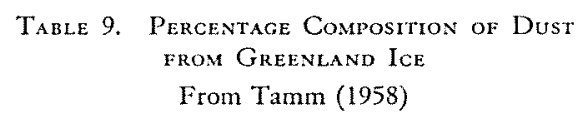

\begin{tabular}{lr}
\hline $\mathrm{SiO}_{2}$ & 62.25 \\
$\mathrm{Al}_{2} \mathrm{O}_{3}$ & 14.93 \\
$\mathrm{Fe}_{2} \mathrm{O}_{3}$ & 0.74 \\
$\mathrm{FeO}_{\mathrm{MnO}}$ & 4.64 \\
$\mathrm{CaO}$ & 0.07 \\
$\mathrm{MgO}$ & 5.09 \\
$\mathrm{Na}_{2} \mathrm{O}$ & 3.00 \\
$\mathrm{~K}_{2} \mathrm{O}$ & 4.01 \\
$\mathrm{P}_{2} \mathrm{O}_{5}$ & 2.02 \\
$\mathrm{Cl}$ & 0.11 \\
$\mathrm{H}_{2} \mathrm{O}$ & 0.06 \\
$\mathrm{Ignition} \mathrm{loss}_{2}$ & 0.34 \\
\end{tabular}

Rankama and Sahama (1950, p. 310), Eriksson (1952, p. 296), and Tamm (1958, p. 238) have reviewed the occurrence of occasional heavy dustfalls over large areas, and Tamm (1958, p. 235) quotes an analysis by Free of dust collected from Greenland ice, which may be considered representative of long-distance fallout (Table 9). According to Tamm and Troedsson (1955, p. 67) the larger part of the potassium in dust, as well as appreciable fractions of the calcium, may not be readily soluble in water, but almost all the sodium is water soluble.

Evidence concerning the actual presence of soil dust in normal air masses has been provided by Twomey $(1953 ; 1954)$, who found it most plentiful during anticyclonic summer weather in Australia, and more abundant in offshore than onshore air streams. Junge (1954, p. 333) also observed insoluble particles in atmospheric aerosols from Massachusetts, even in polar air masses almost devoid of soluble salts. Some reddish-yellow dust particles observed in a few samples from Florida (Junge, 1956, p. 129) were believed to have originated in west Africa and to have travelled across the Atlantic beneath the inversion layer in the atmosphere.
Volcanoes. Over the ages volcanoes have been major sources of the volatile elements carbon, chlorine, and sulfur, which emanate in the form of carbon dioxide and monoxide, hydrochloric acid, hydrogen sulfide, and sulfur dioxide and trioxide (Rankama and Sahama, 1950, p. 184; Rubey, 1951). Local influence of volcanic activity upon rain chemistry is illustrated by analyses of rain water from near Vesuvius (Bottini, 1939), which show a very close correlation between acidity and chloride concentration, the maximum level of hydrochloric acid being $1.8 \mathrm{~m}$ equiv./1.

Air pollation. Another source of atmospheric ions, very important at present, is industrial and domestic air pollution. Meetham (1950, p. 362) compares deposits of total ash, combustible material, sulfates, and chlorides in British urban and rural areas; and the recently established European network for air and precipitation analyses (see quarterly appendices to Tellus) is providing many more data on air-pollution effects, although unfortunately no analyses are being made within cities. Many deposit gauges are, however, located in British cities, and their contents are analyzed for total ash and ignitable matter, sulfate, and chloride, and in many cases for calcium and pH as well (Dept. of Scientific and Industrial Research, 1955). In the U.S.A. a program of urban air analysis is now well established (Anonymous, 1958).

Among industrial sources of atmospheric pollution, metal smelters rank as heavy emitters of sulfur dioxide (Katz, 1939). In the Sudbury area of Ontario, where roughly a million tons of sulfur escape to the air annually, fallout is mainly restricted to within about 5 miles of the three smelters and is quantitatively negligible beyond about 15 miles (Gorham and Gordon, 1960).

Junge $(1954 ; 1956)$ has examined the nature of aerosol pollutants and finds the particles usually of less than $0.8 \mu$ radius. Ammonium sulfate is a major component, and ammonia may be important in facilitating oxidation of sulfur dioxide to sulfate (Junge and Ryan, 1958). Herman and Gorham (1957) reported a marked correlation between ammonia and sulfate in acid rains and snowfalls from Nova Scotia, which parallels Junge's results with the acrosol particles. Other analyses of rainfall (Houghton, 1955; Gorham, 1955b, p. 236; $1958 \mathrm{a}$, p. 160) indicate that free sulfuric acid is also of great importance. Twomey (1953) has observed droplets in the air near Sydney,$$
\ln 1
$$ 
have

nents

anate

xide,

ulfur

lama,

ice of

illus-

near

very

oride

ydro-

mos-

$\mathrm{t}$, is

tham

ash,

rides

e re-

ap-

more

un-

ithin

ever,

ts are

itter,

s for

$c$ and

Australia, which remained liquid at 20 per cent rolative humidity and appeared to consist of sulfuric acid.

Oxidation of sulfur dioxide to sulfate may lake a considerable time, and sulfur may diffuse ii) the gaseous phase far from its industrial sources (Junge, 1956; Junge and Ryan, 1958; Mcctham, 1950, p. 369; 1954). Moreover, sullides are present in soot and can probably oxidize slowly to sulfate. Material from a black soot film, formed on the surface of Windermere in the English Lake District during calm weather, gave a noticeable odor of hydrogen sulfide upon acidification and a distinct re- slightly acid and have a distinct excess of anions over cations. Presumably the balance is made up largely of ammonium, although trace elements (e.g., antimony, arsenic, cobalt, lead, manganese, nickel, zinc) may be abundant in the particulate matter of urban air in England (Stocks, 1958). Lead and zinc are exceptionally plentiful, the former averaging 15-59 and the latter $5-33 \mu \mathrm{g} / 100 \mathrm{~m}^{3}$ in 1 year's samples from 10 towns and cities. Bear (1954) provides analyses of trace elements (copper, cobalt, manganese, molybdenum, zinc) in rain falling at New Brunswick, New Jersey, close to industrial centers, and numerous

Table 10. Ionic Composition of Rain at Knoxville, Tennessee (ppm)

(Macintire and Young, 1923, as recalculated by Conway, 1942, p. 145)

\begin{tabular}{|c|c|c|c|c|c|c|}
\hline & $\mathrm{Ca}$ & $\mathrm{Mg}$ & $\mathrm{Na}$ & $\mathrm{K}$ & $\mathrm{SO}_{4}$ & $\mathrm{Cl}$ \\
\hline City & 2.8 & 0.7 & 3.6 & 5.5 & 14.5 & 6.5 \\
\hline $\begin{array}{l}\text { (utside city } \\
(2.4 \mathrm{~km} \text { from center })\end{array}$ & 0.9 & 0.4 & 1.5 & 2.6 & 5.6 & 3.3 \\
\hline
\end{tabular}

action with lead acetate paper (Gorham, unpublished). Soot from a fireplace in the Winderincre laboratory of the Freshwater Biological Association also contained sulfides.

Gorham (1958a, p. 161; 1958d) has suggested that hydrochloric acid may be a frequent component of air pollution, providing excess chloride to raise the chloride/sodium ratio of rain above that of sea water (Gorham, 1958a, p. 163; Junge and Werby, 1958, p. 419). Such a source probably accounts for the unusually high chloride/sodium ratios observed by Rossby and Egnér (1955) in precipitation from warm and moist air masses entering Sweden from the south and southeast.

In addition to sulfuric and hydrochloric acids, air pollution may add appreciable announts of calcium and potassium to rain (Gorham, 1955b, p. 236; 1958a, p. 160). Analyses by MacIntire and Young (1923) of rain in and just outside Knoxville, Tennessee, show considerable local additions of sodium and magnesium as well (Table 10). These wuthors also analyzed a sample of soot, which wils exceptionally rich in calcium and slightly alkaline. Gorham (1958a, p. 162) analyzed materials dissolved from samples of chimney soot in London, England, which are especially rich in calcium and sulfate, but contain appreciable amounts of the other major ions is well (Table 11). These soot extracts are trace-element analyses are available for urban air in the U.S.A. (Anonymous, 1958).

Organic matter. A last source of soluble ions in atmospheric precipitation is organic debris floating in the air. That this may be quite significant is shown, for instance, by Tamm

Table 11. Soluble Materials in Five Samples of Sioke Solids from London Chimeys

(Gorham, 1958a)

Extract pH 5.6

\begin{tabular}{cc}
\hline & $\mathrm{mg} / \mathrm{g}$ dry wt \\
Cations & 27.2 \\
$\mathrm{Ca}$ & 0.9 \\
$\mathrm{Mg}$ & 7.4 \\
$\mathrm{Na}$ & 3.9 \\
$\mathrm{~K}$ & \\
$\mathrm{Anions}$ & 81.6 \\
$\mathrm{SO}_{4}$ & 27.0 \\
$\mathrm{Cl}$ & 0.4 \\
$\mathrm{NO}_{3}-\mathrm{N}$ &
\end{tabular}

(1958, p. 237) and Viro (1953, p. 36), who report ignition losses for rain and snow solids comparable to the ignition residues. Unpublished data for the Nova Scotian precipitation samples (18 per cent snow) analyzed by Herman and Gorham (1957) showed average ignition residues of $10 \mathrm{ppm}$, and losses of 13 ppm; 17 separate samples of snow averaged 2.7 
ppm ignition residue and 4.3 ppm ignition loss (the samples were not weighted by volume for averaging). Unfortunately there has been no attempt to correlate ionic composition and concentration with the levels of organic matter in precipitation, except for the rather crude correlation established between soot and sulfate in rain from the English Lake District (Gorham, 1955b, p. 234). A close relationship exists between ignition loss and ignition residue in the Finnish snow samples of Viro (1953, p. 36) (Table 7), so that independent correlations with ionic concentrations are difficult to establish in this instance. This was not the case with the Nova Scotian samples where, however, detailed ion analyses were lacking.

Neumann, Fonselius, and Wahlman (1959, p. 138) have reported concentrations of organic carbon in atmospheric precipitation in Sweden ranging from 0.8 to $3.4 \mathrm{ppm}$.

\section{Ion Supply by Soil and Rock Weathering}

General discussion. The capacity of rocks and soils to supply ions by weathering has been investigated in great detail, not only with regard to the nature of the material but also to the influence of various environmental factors upon the weathering process. However, it has not so far been possible to follow separate rainfalls through the soil phase of the hydrologic cycle, in order to evaluate quantitatively the relative influence of various weathering factors, sorption, plant uptake, etc., upon their ionic composition. Therefore only a brief account of weathering and related phenomena is given here, with special attention to aspects where the connection with water chemistry is clear. It is convenient to treat the weathering process under four headings-solution, oxidation or reduction, the action of hydrogen ions, and complex formation. A useful text for a detailed discussion is that of Keller (1957).

Solution. Ordinary solution not involving hydrolysis or acid weathering is important chiefly in sedimentary deposits rich in soluble salts. In the leaching of marine salt beds solubility differences may lead to relative enrichment of alkali chlorides in the resultant lake waters (Clarke, 1924, p. 176). Such solubility differences may also be responsible for marked fluctuations in ionic proportions of river waters during periods of high and low water. During a flood, sodium chloride may be dissolved more rapidly than calcium sulfate from the soil, with the result that chloride may predominate over sulfate in flood waters even though it is less important under normal conditions (Clarke, 1924, p. 72).

Some anomalous chloride/sulfate ratios shown by V. G. Anderson's (1945) data for South Australian stream waters may be explicable on a similar basis. When this ratio is plotted against chloride content (Fig. 2), a distinct peak occurs in the vicinity of $400 \mathrm{ppm}$ of chloride. It seems possible that this level of chloride is reached by streams fed chiefly from rapid surface runoff over arid saline soils, with the very soluble chlorides being dissolved much more readily than the less soluble sulfates. The higher levels of salinity above 500 ppm of chloride could, on the other hand, represent streams percolating more slowly through the soil, and hence able to pick up relatively greater amounts of the slowly soluble sulfates. Even in such waters the chloride/ sulfate ratio is somewhat higher than in the sea, which Anderson claims quite reasonably as the source (via air-borne spray) of the salt. The very dilute stream waters of the Murray River area appear greatly enriched in sulfate relative to chloride (average chloride and sulfate concentrations 1.9 and $0.9 \mathrm{ppm}$, chloride/ sulfate ratio 2.2 as compared with 7.2 in sea water). Inasmuch as the coastal samples of rain from Victoria analyzed by Hutton and Leslie (1958) are if anything impoverished in sulfate, this enrichment (assuming the analyses are reliable at such low concentrations) presumably comes from local sources in the soil.

A different situation is described by Durum (1953) for the Saline River in Kansas. Surface runoff predominates during floods, and the dissolved salts of the relatively dilute river water are dominated by calcium and bicarbonate; during periods of lower flow, however, groundwater influence becomes stronger, and sodium, chloride, and sulfate make up the greater part of the more concentrated salt solution. When flow is minimal the salt concentration in the river water is maximal, and chloride exceeds sulfate in concentration.

Solubility differences may also be responsible for the relative paucity of magnesium and potassium in the Sambhar Lake of northern India, as suggested by Holland and Christie $(1909$, p. 167). This lake is said to owe its high salinity to wind-borne sea salt evaporated during the dry season on the coastal flats of the Rann of Cutch. As sea water evaporates and sodium chloride is precipitated, the remaining bitterns become relatively enriched in magnesium and potassium. If they, being strongly
1. li,

11,11

.11

mal

1111

1.1

l.1111

1.14

. 1411.1

1tantit

pincily

$14+111$

Qimlah

m114km

hlaty

tallio

lavol

Hial in

thingul

indulet

|listat

(1)i! 11

(1)

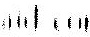

lis $\|_{i:}$

ilin

alla! 
condi-

ratios

ta for

be ex-

atio is

2), a

$0 \mathrm{ppm}$

avel of

from

with

solved

e sul-

500

hand,

Slowly

ck up

oluble

oride/

in the

mably

e salt.

lurray

ulfate

dd sul-

pride/

in sea

les of

$n$ and

hed in

halyses

pre-

soil.

urum

urface

he dis-

water

onate;

ound-

dium,

Ir part

When

in the

xceeds

insible

and

thern

hristie

is high

orated

of the

es and

aining

mag-

rongly
Whifrscent, remain largely unevaporated, llin the salt particles blowing from the Rann w) Cutch to the Sambhar region will be relalucly deficient in magnesium and potassium, in in lact the lake water is.

lirikson (1958, p. 172), on the contrary, - l.ims that aerial supply of sea salt to Sambhar I..1: ma be adequate without invoking salt arrainment by winds sweeping over the dry phosphorus, and carbon compounds in soils. Sulfides of iron are common constituents of rocks and water-logged soils, and oxidation of these sulfides can be an important source of sulfate to natural waters, commonly in the form of sulfuric acid whose strong solvent properties lead to the supply of other rock and soil constituents.

Ferrous sulfide is frequently abundant in

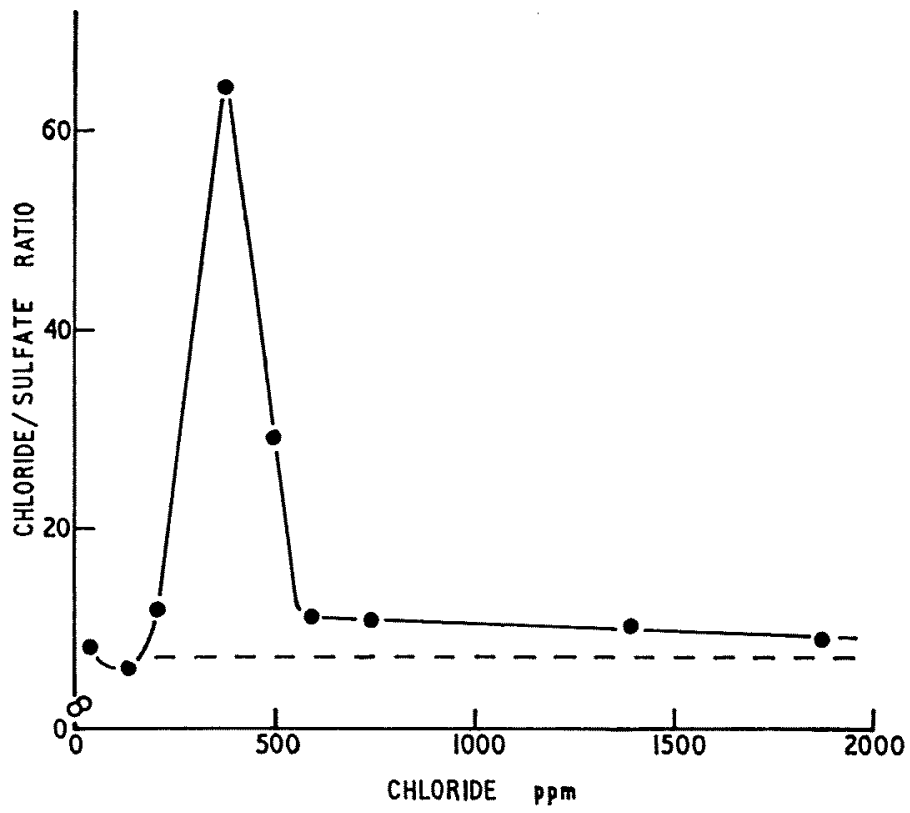

Figure 2. Weight ratio of chloride to sulfate in some Australian stream and river waters. Open circles mark the Murray River basin. Broken line-ratio in sea water

cimstal flats. He further remarks that carbonate precipitation, certainly responsible to some ixicnt for the low calcium concentration in the Simbhar Lake water, may also lower the mangesium level. However, it would be unlikely to affect potassium, and the very low comcentration of this ion would appear to linvor the hypothesis of Holland and Christie lhial a good deal of the salt comes from the woistal flats during the dry season. Very small comicnsation nuclei can apparently be released in large numbers by fragmentation dur1in: the crystallization of large salt droplets (liwomey and McMaster, 1955), which might iiil considerably in the escape of salt from the Iry lats.

()xidation and reduction. These processes Hlat chiefly iron, manganese, sulfur, nitrogen, lake muds, in the surface layers of which a recurrent cycle of oxidation and reduction may take place during the phases of isothermal circulation in winter and of stratified stagnation in summer (Mortimer, 1941-1942; see also Gorham, 1958e). Wiklander and his associates $(1949 ; 1950)$ state that relict lake soils (gyttja) in Sweden may be very rich in ferrous sulfide, especially the saline types. They have also studied the oxidation of sulfide in such soils and find the primary stage of chemical oxidation to free sulfur rapid, while the secondary oxidation of free sulfur to sulfate appears mainly microbiological and comparatively slow.

Oxidation of ferrous iron present in silicates may also bring about ion supply to natural waters, by decreasing the stability of the 
minerals and making them more susceptible to weathering. Reduction of ferric iron present in or coated upon some soil minerals (Carroll, 1958) might perhaps have a similar effect.

Microbiological breakdown of organic sulfur compounds (see Frederick, Starkey, and Segal, 1957) may also add sulfate to natural waters, again commonly in the form of sulfuric acid. This strong acid is responsible for much of the acidity of highly organic woodland soils (Gorham, 1958b; 1958f), of bog waters (Gorham, 1956b, p. 378; 1958b; Gorham and Cragg, 1960 , p. 179) and also of peaty lake waters, where a distinct correlation between acidity, sulfate, and dissolved organic carbon has been described (Gorham, 1957b, p. 17).

Reduction may decrease sulfate concentration in natural waters, with a concomitant rise in alkalinity. It is particularly noticeable in the stagnant bottom waters of lakes during summer stratification, when bacteria have used up the free oxygen originally present and very low or negative redox potentials prevail at the mud-water interface (Mortimer, 1941-1942; see also Hutchinson, 1957, Chapter 13, p. 753).

Action of hydrogen ions. If free acids are absent, hydrogen ions for rock and soil weathering are provided by the dissociation of water molecules, in the process of hydration and hydrolysis (Robinson, 1949, p. 47; Keller, 1957, p. 21, 24). This process is believed to be especially significant for weathering in the tropics, where the rather dilute stream waters carry large proportions of dissolved silica, and the soils are usually lateritic and rich in iron and aluminium sesquioxides (Jenny, 1950, p. 59). Strongly acid podzols may occur on extremely base-deficient substrata in tropical lowlands, however, although they are more characteristic of cool temperate regions. Colorless "white-water streams" are apparently typical of lateritic regions, and "black-water streams" colored brown by dispersed humus compounds drain the tropical podzols (Richards, 1941). According to Sioli (1956) both have very dilute waters, the latter more strongly acid and deficient in calcium. (See, however, the Essequibo River in Table 3; this water is strongly dominated by bicarbonates and thus cannot be very acid).

Berg (In press) states that black waters are also characteristic of the streams of the central basin of the Congo, covered mainly by swamp forests. The variable amount of humic substances, originating from incomplete decomposition of vegetable material under swamp-forest conditions, is responsible for the low $\mathrm{pH}$ of these waters $(3.5-5.2)$, whereas the poor solubility and small variety of soil minerals in that part of the world is responsible for the low mineral content of the Congolese stream waters (specific conductivity due to ions other than hydrogen ions averages about 10 micromhos, total hardness is equivalent to about $0.6 \mathrm{ppm}$ calcium).

Carbonic acid is undoubtedly a major source of hydrogen ions for weathering. Carbon dioxide exists in normal air at a concentration of 0.03 per cent by volume, but volcanoes may raise concentrations locally and have undoubtedly been of great significance over the ages in supplying the air with this gas. Biological respiration greatly increases carbon dioxide in soil air; for instance, Romell (1922) recorded a maximum of 2.8 per cent in forest soils with hardpan zones, and of 5-6 per cent in very wet soils under spruce. For rain water Clarke (1924, p. 54) quotes Bunsen's analyses of dissolved carbon dioxide, which range from 2.14 per cent by volume at $20^{\circ} \mathrm{C}$ to 2.92 per cent at $0^{\circ} \mathrm{C}$. At the other extreme, the interstitial water of anaerobic lake muds may contain as much as 5-35 per cent (Koyama, 1953, p. 117). The importance of carbonic acid in weathering is well illustrated by the high proportion of bicarbonate ions in most river waters. Even those of $50 \mathrm{ppm}$ salinity or less and draining only igneous rocks are predominantly bicarbonate waters (Conway, 1942, Tables 7, 8, p. 134-135). The significance of biological carbon dioxide production is illustrated by Metzger (1928), who found consistently higher bicarbonate concentrations in soil samples close to plant roots than in samples farther from them.

Strong acids may also be important. Sulfuric acid, either from air pollution or from organic decay, may be abundant in rainfall and in certain types of soils (Gorham, 1958b; 1958f). Hydrochloric acid is sometimes plentiful in urban rain (Gorham, 1958d), and volcanocs can supply large amounts locally (Bottini, 1939). Nitric acid may be significant too, since oxidation of ammonia to nitrate is common in soils. Gorham (1958a, p. 175) has shown that nitrate is the most abundant anion in the soil solutions of mull types of woodland humus layer in the English Lake District.

Colloidal acids, whether acid clays or the so-called humic acids, may also supply large amounts of hydrogen ions for soil weathering, as may plant roots, whose adsorptive surfaces 
$\mathrm{pH}$ of

hoor solu-

ils in that

the low

in waters

her than

cromhos,

$0.6 \mathrm{ppm}$

or source

Carbon

ntration

oes may

ave un-

over the

Biologi-

dioxide

recorded

oils with

very wet

ke (1924,

dissolved

2.14 per

cent at

terstitial

ontain as

p. 117).

athering

rtion of

ts. Even

draining

intly bi-

bles 7,8 ,

jiological

pated by

ly higher

samples

farther

Sulfuric

organic

and in

; 1958f).

ntiful in

rolcanoes

(Bottini,

bo, since

mmon in

bwn that

the soil

d humus

s or the

ply large

pthering,

surfaces are strongly saturated by these ions (Keller .nicl Frederickson, 1952; Keller, 1957, p. 30). licntative evidence suggests that the more primitive among the higher plants are more rlfective in such weathering (Lewis and Eisenincnger, 1948). Animals may also influence the weathering process. (See Lutz and Chandler, 1946$, p. 70$)$.

Nccording to Berg (In press) most of the hyylrogen ions in blackwater streams of the Congo appear to come from dissociation of humic acids, although strong acids are presum. Why also present in waters below $\mathrm{pH} 4$. Shlaipiro (1957) has recently extracted strongly will humic compounds from organic matter - lissolved in North American lake waters.

Complex formation. Ions can also be reuneved from rocks and soils by chelation, or wher forms of complexing. The ion is joined (1) the chelator, usually a complex organic molecule, by more than one valence bond, and is prevented from combining with other ions, Whough it remains in solution. The significance if chclation in weathering is not clear as yet, liII, since complex organic molecules are common in surface soils and on rock faces covered by plants, it may be expected to play 1 part. Not only organic molecules deriving I 1 om soil humus, but also excretions from plant rewts or micro-organisms, may be active comflexing agents. The subject is briefly discussed hy Schatz et al. (1954) and by Keller (1957, 1. 33 )

\section{Significance of Ion Exchange}

lixchange of ions between soils and the soil whlution, or between muds and the overlying walters in lakes, also affects ion circulation, "Mllough an equilibrium may often be attained uwing to the finite adsorptive capacity of the will colloids. Thus in certain circumstances the wrrall composition of water percolating the surfice soil may be only little affected by such processes (Troedsson, 1952; cf. also Eriksson, 1155, p. 249), although short-term disturbances and fluctuations do occur. The very process of werllhering commonly involves some degree if im cxchange, with hydrogen ions replacing micial ions attached to the soil minerals.

Simne of the acidity of bog waters may be Hew wexchange of metal ions in rainfall for hyilrogen ions generated during organic decay .uil indsorbed on peat colloids, the latter being displaced into solution and lowering $\mathrm{pH}$ (ciorham and Cragg, 1960, p. 179). The preAhminance of hydrogen ions on the adsorption complex of very acid peats has been pointed out by Malmer and Sjörs (1955, p. 69) and by Gorham (1956a, p. 148). During dry weather another type of ion exchange may occur, in which oxidation of sulfide produces free sulfuric acid whose hydrogen ions then replace metal ions adsorbed by the peat, and so alter ionic ratios in the bog waters (Gorham, 1956b, p. 379). For example, during very wet weather the sodium/chloride and magnesium/chloride ratios in bog waters at Moor House in the English Pennines are very close to values for sea water (sodium/chloride in sea water 0.56 , in bog water 0.53 ; magnesium/chloride in sea water 0.067 , in bog water 0.063 ). In very dry weather, however, ion exchange greatly increases these ratios in bog water (sodium/chloride 0.73 ; magnesium/chloride 0.136 ). The magnesium/chloride ratio becomes especially high, because the divalent magnesium ion is much more strongly adsorbed by the peat colloids than is the monovalent sodium ion. If the metal ions adsorbed on peat colloids could all be relcased into the surrounding bog waters they would be greatly enriched (Malmer and Sjörs, 1955, p. 70; Gorham, 1956a, p. 148). Malmer and Sjörs find ratios of exchangeable to dissolved ions as follows: sodium $5-6$, potassium 25-150, magnesium 90-240, and calcium 150300. This accords with the expected order of adsorption.

In lakes the importance of ion exchange between muds and waters has been stressed by Mortimer (1941-1942), who suggested that during summer stagnation adsorbed bases may be released into anaerobic bottom waters by reduction and breakdown of an iron-silicahumus adsorption complex. Once aerobic conditions are restored at the onset of isothermal circulation in autumn, this complex will be reconstituted, and bases will be adsorbed from the water again. However, the evidence for this is circumstantial. The marked fall in alkalinity of bottom waters at the autumnal overturn, cited by Mortimer as evidence of base adsorption, may well be due mainly to dilution, because of the mixture of a very small volume of concentrated hypolimnion water with a very large volume of more dilute epilimnion water. In aerating anaerobic mudwater cores from the bottom of Esthwaite Water (the lake chiefly investigated by Mortimer), the writer could detect no significant change in the concentration of calcium, magnesium, sodium, and potassium by the time precipitation of ferric hydroxide was approxi- 
mately complete ( 48 hours, as indicated by cessation of the decline in conductivity caused by oxidation of dissolved ferrous iron).

Nevertheless, a continual release of ions from mud particles to the water surrounding them probably does take place, for the interstitial water of the mud is commonly richer in salts than is the overlying water. Table 12 shows this clearly; the data for Esthwaite Water are new, and those for the Grosser Plöner See have been taken from Ohle (1955b). Hypolimnetic water just above the mud is also usually richer important source of such hydrogen ions is suggested by recent studies of Mortimer and Mackereth (1958, p. 931) on the north Swedish lake Torneträsk, but oxidation of sulfide (either organic or inorganic) may well provide another. Gentle aeration of undisturbed mudwater cores from Esthwaite Water, without agitation of the mud surface, leads to considerable acidification, and the lowering of $\mathrm{pH}$ in water overlying the mud is closely correlated with a risc in sulfate concentration there. Starting with mud-water cores in which

Table 12. Iong Concentrations in the Botrom Waters of Lakes and in the Interstitial Waters of Their Muds

\begin{tabular}{|c|c|c|c|c|c|c|c|c|c|}
\hline & $\begin{array}{l}\text { Sum of four } \\
\text { cations } \\
\text { m equiv. } / 1\end{array}$ & $\begin{array}{c}\text { Specific } \\
\text { conductance, } \\
\text { micromhos } \\
\text { at } 18^{\circ} \mathrm{C}\end{array}$ & $\mathrm{Ca}$ & $\mathrm{Mg}$ & $\mathrm{Na}$ & ppm & $\mathrm{HCO}_{3}$ & $\mathrm{SO}_{4}$ & $\mathrm{Cl}$ \\
\hline \multicolumn{10}{|l|}{$\begin{array}{l}\text { Esthwaite Water, } \\
\text { England }\end{array}$} \\
\hline $\begin{array}{l}\text { Bottom water } \\
\text { Mud water }\end{array}$ & $\begin{array}{l}0.88 \\
1.21\end{array}$ & $\begin{array}{l}\text { n.d. } \\
\text { n.d. }\end{array}$ & $\begin{array}{l}11 \\
16\end{array}$ & $\begin{array}{l}1.4 \\
1.8\end{array}$ & $\begin{array}{l}4.7 \\
5.2\end{array}$ & $\begin{array}{l}1.1 \\
1.8\end{array}$ & $\begin{array}{l}\text { n.d. } \\
\text { n.d. }\end{array}$ & $\begin{array}{l}\text { n.d. } \\
\text { n.d. }\end{array}$ & $\begin{array}{l}\text { n.d. } \\
\text { n.d. }\end{array}$ \\
\hline \multicolumn{10}{|c|}{$\begin{array}{l}\text { Grosser Plöner See, } \\
\text { Germany }\end{array}$} \\
\hline $\begin{array}{l}\text { Bottom water } \\
\text { Mud water }\end{array}$ & $\begin{array}{l}\text { n.d. } \\
\text { n.d. }\end{array}$ & $\begin{array}{l}387 \\
460\end{array}$ & $\begin{array}{l}49 \\
65\end{array}$ & $\begin{array}{l}5 \\
8\end{array}$ & $\begin{array}{l}\text { n.d. } \\
\text { n.d. }\end{array}$ & $\begin{array}{l}\text { n.d. } \\
\text { n.d. }\end{array}$ & $\begin{array}{l}165 \\
205\end{array}$ & $\begin{array}{l}28 \\
46\end{array}$ & $\begin{array}{l}36 \\
56\end{array}$ \\
\hline
\end{tabular}

in salts than is surface water, as shown in Table 13 , which compares cationic concentrations and proportions in the epi- and hypolimnion of Esthwaite Water with those of the interstitial water of the muds, and of the cations adsorbed on the mud colloids. This comparison, from previously unpublished data, shows that the relative importance of sodium, supplied almost wholly by atmospheric precipitation, declines from the surface waters to the cations adsorbed on the muds, while the importance of calcium, contributed mainly by soil weathering, becomes steadily greater. The enrichment of calcium in the mud water and in the hypolimnetic water strongly suggests displacement of calcium adsorbed on mud colloids into the surrounding water, followed by diffusion into the overlying hypolimnion. Such upward diffusion would be especially favored during stormy periods when turbulence stirs up the surface mud layers (Gorham, 1958c).

The driving force for such a diffusion is probably the replacement of adsorbed calcium ions by hydrogen ions generated in the mud through oxidation of carbon or sulfur compounds. That carbonic acid is likely to be an the water (after acration) had a $\mathrm{pH}$ of 7.6 and a sulfate concentration of $0.2 \mathrm{~m}$ equiv. $/ 1$, the minimum $\mathrm{pH}$ observed in four cores aerated for 135 days was 4.6 , in a water with $1.3 \mathrm{~m}$ equiv. 11 of sulfate. In this unpublished experiment the logarithmic $\mathrm{pH}$ values were linearly related to the arithmetic values for sulfate in the core waters.

In contrast, Ohle (1955b) has carricd out experiments from which he concludes that the calcium and bicarbonate concentrations of some soft German waters may have been reduced through ion exchange, adsorbed hydrogen ions on the rather peaty mud being replaced by calcium ions from the water. Such an $\mathrm{ex}^{-}$ change either with lake muds or with surrounding soils may be the cause of very low calcium concentrations (well below levels in average precipitation at several inland American stations) observed in some Wisconsin seepage lakes (Table 5).

In other experiments Koyama and Sugawara (Sugawara, 1951, p. 8) reported that the colloidal floc in lake waters can adsorb not only alkaline earths but also sulfates. After sedimentation these ions may be released into the

$$
\text { 11 }
$$

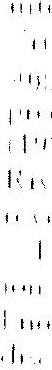

11,114

inst:

$1+\cdots, \cdot 1$

if $1+i, 1$

(1......

")

1

$+1$

$\mid+1,1$

lisin

with

1961: ins

Allager

illit,

intwin

hingy

Hit il

$1 \%$

lit

$|+\cdots, \ldots|$

(in) II

111+1|क

mingth

|ll, in!

$n 1,1$ का

"1+1414

a:thi!

I twina

1.11. 1

il. 
As is sug-

her and

Swedish

(either

vide an-

ad mud-

without

to con-

of of $\mathrm{pH}$

dy cor-

itration

n which

$0_{4} \quad \mathrm{Cl}$

36

56

7.6 and

4 , the

gerated

$1.3 \mathrm{~m}$

experi-

linearly

Ifate in

ed out

hat the

of some

educed

en ions

ced by

an ex-

th sur-

try low

vels in

Ameri-

in seep-

gawara

the col-

bt only

dimen-

tho the
Inlemstitial water of the mud by some sort of "riprning" process. Hesse (1958, p. 178) has mggested that diatomite in lakes adsorbs appreciable sulfate, and Carritt and Goodgal (1954) have shown sulfate sorption by Roanoke liver solids; the reaction, however, is readily uresible with sulfate-free solutions.

1) hagenesis of sediments may well result in InI exchanges, although little appears to be l. Inw - liscussed an interesting transformation of illitic supplied from sea spray; yet in the well water less than $1 \mathrm{~m}$ below the dune surface the calcium/bicarbonate ratio (in equivalents) is considerably less than unity, while sodium/ chloride and magnesium/chloride ratios are much greater than in sea water (Gorham, $1958 \mathrm{~g}$, p. 378). The ion exchange involved is probably similar to that postulated for arid alkali soils of the solonetz type, common in dry continental climates. (Cf. Robinson, 1949, p. 387.)

Table 13. Concentration and Composition of Cations in the Water and Absorbed on the Mud of Estuwatte Water

\begin{tabular}{|c|c|c|c|c|c|}
\hline & $\begin{array}{l}\text { Sum of } \\
\text { four cations } \\
\text { m equiv. } / 1\end{array}$ & $\mathrm{Ca}$ & $\begin{array}{c}\mathrm{Mg} \\
\text { m equiv. } \% \text { of total cations }\end{array}$ & $\mathrm{Na}$ & $\mathrm{K}$ \\
\hline on water & 0.77 & 58 & 14 & 26 & 3 \\
\hline $\begin{array}{l}\text { mion water } \\
\text { mud }\end{array}$ & 0.88 & 61 & 13 & 23 & 3 \\
\hline al water & 1.21 & 65 & 12 & 19 & 4 \\
\hline
\end{tabular}

(1) 11,41

A.tinlwions on mind colloids*

\section{$11 \quad 1.5 \mathrm{~cm} \mathrm{depth}$}

$1.1 .5 \mathrm{~cm}$ depth

$1 \% 5.5 \mathrm{~km} \mathrm{depth}$

$47.5 \mathrm{~cm}$ depth

$4.5 \mathrm{~cm}$ depth

- lixchangeable with ammonium acetate

11. Mloritic material in terrestrial clays transfrord to an estuarine environment; magnesium wis absorbed by the clays preferentially to pminsium. According to Mason (1952, p. 136) dingranctic alteration of montmorillonite to Illic may be the process mainly responsible for romovil of potassium from natural waters; the hinge involves incorporation of this ion into ihe disy mineral.

The influcnce of ion exchange is less clear in linkr willers than in deep-well waters, which frrevlate through long columns of soil and $1 \mathrm{k} k$ mincrals with widely varying amounts and pripurtions of adsorbed ions. Softening of miginilly hard waters is of frequent occurrence (Kunick, 1924; Riffenburg, 1925; Foster, 1950), .mil similar softening has been postulated for prommil watcr supplying a very shallow well in aind dunes at Blakeney Point in Norfolk, 1.nplind. At this site calcium is probably suppliril almost cntirely from shell fragments in llir suml, and sodium and magnesium are
Where fresh-water aquifers become contaminated by sea water, the contact zone may exhibit much higher concentrations of alkaline earths than would a simple mixture of the two waters, owing to displacement of adsorbed calcium and magnesium by sodium from the advancing sea water (Piper, Garrett, and others, 1953, p. 87, 105).

\section{Mode of Water Percolation}

Whether water flows as superficial runoff or as deep ground water may exert a profound effect upon ionic concentrations in river and lake waters. Durum's (1953) study of the Saline River in Kansas illustrates this point. He found that during 1947 and 1948 surface runoff accounted for 65 per cent of total stream discharge, but only 24 per cent of dissolved solids carried, since the ground water was much richer in dissolved materials. In Wisconsin, seepage lakes fed largely by runoff are extremely dilute; the mode for specific conductance (in general 
proportional to total dissolved salts, see Rodhe, 1949) is 12 micromhos (Juday and Birge, 1933). Wisconsin drainage lakes, with inlet and outlet streams draining deeper soil horizons, are much more concentrated, with a specific conductance mode of 67 micromhos. Hooper (1956, p. 123) reports similar results for the alkalinity of lake waters in Michigan.

In contrast Pennak (1958) records considerably higher ash and organic-matter contents in pressed or lysimeter waters are much more concentrated, partly because of greater evaporation, but they may also show a very different proportionality among the various ions. Table 14 compares lysimeter drainage and expressed soil solutions with normal ground water and surface waters in middle Sweden (Troedsson, 1955, p. 179), the last two being much alike in this area of shallow and base-deficient soils. The surface waters and ground waters are

Table 14. Comparison of Waters Expressed from Soll by Pressure with Ground Watfrs AND LAke Waters from the Same Areas (ppm)

\begin{tabular}{|c|c|c|c|c|c|c|c|c|}
\hline & $\mathrm{Ca}$ & $\mathrm{Mg}$ & $\mathrm{Na}$ & $\mathrm{K}$ & $\mathrm{HCO}_{3}$ & $\mathrm{SO}_{4}$ & $\mathrm{Cl}$ & $\mathrm{NO}_{3}-\mathrm{N}$ \\
\hline \multicolumn{9}{|l|}{ English Lake District } \\
\hline $\begin{array}{l}\text { Expressed soil solution (pH } 4.2 \text { ), } \\
\text { from organic mor humus layers }\end{array}$ & 1.1 & 0.9 & 9.2 & 5.8 & nil & 17.5 & 11.5 & 0.1 \\
\hline $\begin{array}{l}\text { Lake water of similar chloride } \\
\text { concentration* }\end{array}$ & 14.5 & 2.5 & 5.7 & 0.9 & 35.9 & 14.1 & 11.3 & v. low \\
\hline $\begin{array}{l}\text { Expressed soil solution from } \\
\text { circumneutral mull humus layers }\end{array}$ & 10.0 & 1.6 & 8.7 & 4.4 & 8.1 & 9.6 & 7.6 & 7.8 \\
\hline $\begin{array}{l}\text { Lake water of similar chloride } \\
\text { concentration* }\end{array}$ & 5.3 & 1.1 & 4.2 & 0.4 & 10.7 & 7.9 & 7.4 & v. low \\
\hline \multicolumn{9}{|l|}{ Central Sweden (Corest land) } \\
\hline Expressed soil solution & 12.8 & n.d. & 8.7 & 3.0 & & & & \\
\hline Water seeping into lysimeters & 7.0 & 2.3 & 5.5 & 4.7 & & & & \\
\hline $\begin{array}{l}\text { Ground waters from wet soils } \\
\text { with bog moss }\end{array}$ & 5.6 & 1.0 & 3.7 & 0.7 & & & & \\
\hline Normal ground waters & 3.0 & 1.3 & 2.8 & 0.4 & & & & \\
\hline Surface waters & 3.2 & 1.5 & 5.1 & 0.8 & & & & \\
\hline
\end{tabular}

* Values calculated from data of Mackereth (1957)

Colorado montane (2500-3200 m) lakes with only temporary outlets than in ordinary drainage lakes there. Probably the latter, because they are deeper, are less subject to evaporative concentration, and they may, in addition, be fed from above by dilute alpine streams. The alpine waters above $3200 \mathrm{~m}$ are only about half as concentrated as those of the montane drainage lakes, perhaps owing mainly to greater precipitation at higher altitudes, as well as to a lesser abundance of the morainic glacial soils commonly found at montane levels.

Troedsson (1955, Chapter 5, p. 99) and Gorham (1958a, p. 176) found that solutions in intimate contact with the mineral soil, as for example those seeping into lysimeters or expressed by pressure, may exhibit ionic concentrations very different from those of normal ground and lake waters, which percolate through the soil mainly along crevices, root channels, worm tracks, stone/soil interfaces, etc. (Tamm and Troedsson, 1957). The ex- considerably more dilute than the expressed and lysimeter waters, which are enriched particularly in potassium. Table 14 also compares solutions expressed from the humus layers of woodland soils in the English Lake District and waters of similar chloride content from lakes (Gorham, 1958a, p. 175). The humus layers include both strongly acid and organic mor types from heavily leached knolls with semipodzolic soils, and faintly acid mull types from flushed brown earths along the edges of streams and lakes (described by Gorham, 1953). The mor waters have been more concentrated by evaporation than the mulls, as shown by higher chloride concentrations. The ionic compositions of the expressed mull and mor soil solutions differ not only from one another but also very markedly from those of the lake waters. Potassium is unusually high in both types of soil solution, presumably owing to release from decomposing leaves, which are rich in this element (Ovington, 1956). The mor solutions
1...

$1+\cdots 11$

$\ln 1+1$

$111+11 \|^{\circ}$

1111

(:)

$1 / 114$

I) Sho

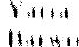

If.t.th

in lin,

anirl,

inuli

fimane

$\mathrm{Va}$

Alillin

silind

Sinal

Ale a

niver

milen

HI:II!

(linh

hullu

jê1

$1 / 1$

|N||

' I I

Ifill.

11

ploril i1) thental 


\begin{tabular}{|c|c|c|c|c|c|}
\hline $\begin{array}{l}\text { more } \\
\text { evapo- } \\
\text { Tifferent } \\
\text { Table }\end{array}$ & \multicolumn{5}{|c|}{$\begin{array}{c}\text { lami: 15. Average Composition of Ground } \\
\text { Watirs and River Waters in Japan (ppm) } \\
\text { (Hanya, 1951) }\end{array}$} \\
\hline and & & $\mathrm{Ca}$ & $\mathrm{Mg}$ & $\mathrm{SO}_{4}$ & $\mathrm{Cl}$ \\
\hline & 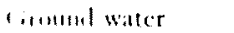 & 15 & 5.7 & 13 & 15 \\
\hline alike & molles river waters & 10 & 3.7 & 11 & 10 \\
\hline & $1.11 \mathrm{~g} / \mathrm{river}$ waters & 11 & 4.1 & 13 & 10 \\
\hline
\end{tabular}

Ifum strongly leached soils are extremely defi iont in calcium, as expected. The mull solulinis:are, on the other hand, uncommonly rich i1) iitratc, because of the activities of bacteria iil braking down organic nitrogen compounds ninl, in these open and circumneutral soils, oxidizing to nitrate the ammonia that is firmed.

Vuriution in water composition because of lilfrent modes of percolation was also obtrived by Arrhenius (1952) who found that Swodish well waters contain three to four times Ho amount of soluble salts found in Swedish river waters. Hanya (1951) also found conailcribly greater amounts of salt in Japanese unuml waters than in river waters there (linble 15). Sulfate, however, was not notably lingher, prerhaps owing to some reduction during frratution through the soil.

\section{INVIRONMENTAL FACTORS \\ INIIUULNCING IONIC (IMIIOSITION}

\section{G limate}

The original salt concentration of atmosHicric precipitation may depend on the amount if tuow or rain falling. Light showery rains are inually much more concentrated than are heavy falls (Sugawara, Oana, and Koyama, 1949; Gorham, 1958a, p. 152), and salinity may sometimes be related to rain intensity (Woodcock and Blanchard, 1955, p. 443). Turner (1955) showed that raindrop salinity may be greatly influenced by conditions below cloud base; he demonstrated a relationship between sodium chloride salinity and raindrop size.

The high contents of calcium, bicarbonate, and especially sulfate in atmospheric precipitation from the arid Ukraine, as compared with precipitation from the moister northwestern parts of the U.S.S.R. (Alekin and Brazhnikova, 1957), are probably due mainly to climatic

Iainil 16. Comparison of the Observed Concentrations of Chloride in Australian River Waters with Those Calculated from Rainfall Analyses and River Discharges (V.G. Anderson, 1945)

\begin{tabular}{|c|c|c|c|c|c|}
\hline \multirow{3}{*}{$\begin{array}{c}\text { Catulinent } \\
\text { atea }\end{array}$} & \multirow{3}{*}{$\begin{array}{c}\text { Mean annual } \\
\text { rainfall (ins.) } \\
1897-1914\end{array}$} & \multirow{3}{*}{$\frac{\text { Discharge }}{\text { Rainfall }}$} & \multicolumn{3}{|c|}{ Mean chloride concentration (ppm) } \\
\hline & & & In rain & & \\
\hline & & & $1917-1925$ & Calculated & Observed \\
\hline Hür Muray & 33.19 & 0.283 & 1.0 & 3.5 & 3.4 \\
\hline (1) Ghammassy & 63.74 & 0.520 & 2.7 & 5.2 & 4.8 \\
\hline Yarath & 44.61 & 0.311 & 4.4 & 14.2 & 15.3 \\
\hline Nharwon & 25.33 & 0.075 & 8.4 & 112 & 134 \\
\hline Italnatia & 28.05 & 0.034 & 6.7 & 197 & 203 \\
\hline
\end{tabular}

differences. Were it not for the dry climate of the Ukraine, the soils would not contain such large amounts of easily soluble salts, and dustfall would not be so great either. Similar differences are apparent in Soviet rivers.

The balance between precipitation and evaporation has a marked effect upon the concentration of surface waters. This is brought out by Table 16 , in which the chloride concentration in the rain and the ratio of river discharge to rainfall are seen to act jointly in determining the chloride concentration of Australian river waters (V. G. Anderson, 1945). The good agreement between observed and calculated values suggests little dry fallout or capture of salt particles by vegetation, in marked contrast to results elsewhere. The influence of moisture balance may be scen too in the increased concentrations of chloride (supplied almost entirely by rain) in lowland as compared with upland lakes in the Cairn Gorm mountains of Scotland (Gorham, 1957f), illustrated in Figure 3. The effect of climate is also illustrated by the increase in salt content with decreasing elevation of lakes in central 
Sweden. Köhler (1937) records similar results from chloride analyses of dilute Norwegian lakes at very high altitudes.

The influence of moisture balance upon ionic propòrtions in surface waters was also examined in the discussion of Clarke's views on the ide content of Walker Lake in the Great Basin of the western United States. They suppose that a period of severe aridity dried up the lake, so that its salts were all deposited and covered by sediments when the lake reformed. In other lakes, which apparently did not dry

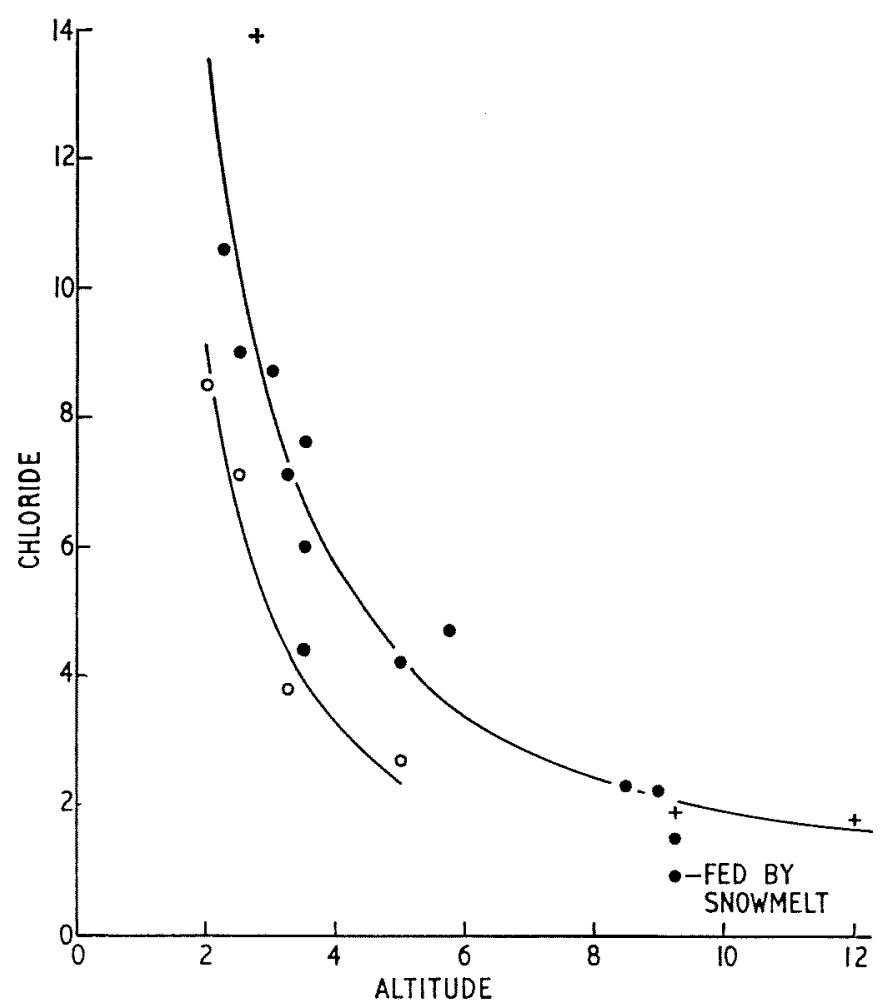

Figure 3. Chloride concentrations of lake waters at varying elevations in the Cairn Gorm region of Scotland. The curve has been fitted freehand to $\log / \log$ plots. Solid circles represent small lakes, and open circles large lakes receiving much upland drainage. Crosses represent springs.

importance of climate in determining the chemistry of both river waters and the lake waters of closed drainage basins. Past climates may also affect the composition of lake waters at the present day, insofar as they condition geologic processes. For instance, Gorham (1957c, p. 26) has suggested that the high salt contents of most of the Cheshire meres in England, which are especially rich in chloride and sulfate, reflect the arid conditions in which the underlying Triassic Keuper marls were deposited. An even more extreme situation has been suggested by Broecker and Walton (1959, p. 615) to account for the relatively low chlor- out, much higher chloride concentrations are observed.

Temperature is a climatic factor of the utmost importance, not only in determining moisture balance, but in other ways as well. Snow stored as glacier ice may lose salts through selective washout of intercrystalline brines during the summer melting period (Gorham, 1958h). Strøm (1939) states that lakes fed chiefly by glacier meltwater are notably poor in electrolytes.

According to Cunningham (1941) sea temperature may control the chloride content of sea fog by some sort of evaporation effect; for

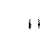

1,

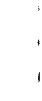


Great Basin cy suppose red up the posited and reformed. d not dry

ions are

the utermining as well. through brines Gorham, kes fed bly poor sea temintent of ffect; for
III Iluving over warm water contains many uume hilurite particles than air moving over whl waler. The number of days the air travels wer lle occan is important too. Cold weather 111.1 il:o have an indirect effect upon the compusition of rain by inducing greater fuel innlumbion and hence increasing acid air polluum ly sullates and chlorides in winter (see Ninliam, 1950, p. 362; Dept. of Scientific and Imlinstrial Research, 1955, p. 13; Barrett and Inorlin, 1955, Fig. 4, p. 254).

limperature of course influences the chemis14. of surlace waters greatly. In cold climates 111,4 splitting of rocks exposes fresh surfaces to walluering. Tropical rivers, which drain inmply weathered soils subjected to a diflinul iype of breakdown, are commonly poor 11 dissolved salts and are peculiar in that a lange part of their total salinity is accounted for liv vilica (Clarke, 1924).

lircring out of salts may also be of local 111 pritance during cold winter weather in high litiludes. Boyd (1959) found that some Alaskan wilcrs become strongly concentrated when munt of the water crystallizes as ice. Ion proporI mis may also be affected, as in some highly umcontrated waters from closed basins in sinkatchewan. These waters are normally satufillol with sodium sulfate and show freezing wit and re-solution of sodium sulfate crystals linring cold and warm periods respectively (Rilwson and Moore, 1944, p. 149). A similar flirmmenon is observable in the Karaboghaz inll of the Caspian Sea (Clarke, 1924, p. 168). Ihumpson and Nelson (1956, p. 237) suggest thit some sulfate lakes may have formed llinwgh frigid concentration where marine sales were cut off in lagoons or embayments of llie seis.

limperature stratification in lakes can lead w. 'nrichment of bottom waters in salts (Table 13 , and sometimes to their depletion in sulfate (1)rumgh reduction) if the hypolimnion beimucs anaerobic (Mortimer, 1941-1942). The 11 wes of stratification developed in different pinl of the world vary greatly with temperaiutc regime (Hutchinson, 1957, Chapter 7, 1). 1,6$)$.

Wother significant climatic factor is wind, 14. Huse direction and speed may strongly affect 1/1. iremical composition of atmospheric pre1plitation. Junge $(1954 ; 1956)$ and Twomey $(1953 ; 1954)$ reported differences in the chemiil constitution of continental and maritime wrumols, and Woodcock (1953, p. 364; see also Winulcock and Mordy, 1955, p. 296) showed how sea-salt concentration in the air at cloud level near Hawaii increases with high winds. The range is from about $2 \mu \mathrm{g} / \mathrm{m}^{3}$ with winds of force 1-2 (Beaufort scale) to about 400-500 $\mu \mathrm{g} / \mathrm{m}^{3}$ with hurricane winds of force 12 . There is a linear relation between the logarithm of sea-salt concentration and wind force on the Beaufort scale; with overland winds such a relationship is not found (Junge, 1954, Fig. 6, p. 329).

Concerning rainfall, Eriksson (1952, p. 289) summarizes the earlier work which describes the influence of wind speed and direction upon chloride concentrations. Barrett and Brodin $(1955$, p. 257$)$ point to the increased acidity of Swedish precipitation during February-March (mean pH 4.7-4.8), when the predominant air flow during wet spells is from the south and brings air pollution into the country from the great industrial centers of Europe. In May not only does fuel-combustion decline, but also air flow from the north develops in connection with the anticyclone situated over Britain and the North Sea, so that mean $\mathrm{pH}$ rises to about 5.7. In summer the blocking anticyclone breaks down, and south or west winds again carry in some acid aerosols, bringing $\mathrm{pH}$ values down again to intermediate levels around 5.2. The work of Rossby and Egnér (1955) indicates also that chloride/sodium ratios greater than those of sea water (up to 3.5 as against a sca water ratio of 1.8 ) characterize precipitation from air streams coming from the south and passing through heavily industrialized regions, while very low ratios (down almost to zero) are typical of precipitation from air masses of northern origin.

The influence of wind direction and wind velocity upon the anionic composition of daily rain samples in the English Lake District has been shown by Gorham (1958a). His Figure 4 (p. 155) illustrates the importance of winds from the southwest in transporting chlorides into the area; the distance between the sea and the sampling point is least in that direction. Southeast winds evidently bring in most of the sulfate, as sulfuric acid, from the great industrial areas lying south and east of the Lake District. The effect of wind speed is much greater upon chlorides than upon sulfates (see Gorham, 1958a, Fig. 6, p. 157), presumably because it affects not only transport of sea-salt particles inland but also their entrainment into the air from the sea surface (Woodcock, 1953; p. 364; Woodcock et al., 1953). The magnitude of chloride supply during storms may be 
gauged by the fact that a 2-day westerly gale in the English Lake District raised the concentration of sodium in Ennerdale Water by 0.7 ppm, equivalent to a deposit of some 3000 tons of sea water in the drainage basin (Mackereth and Heron, 1954).

The influence of wind direction upon the composition of lysimeter drainage in a New England forest stand has been indicated qualitatively by Joffe (1940, p. 58), who found that a series of peaks and dips in chloride translocation through the $A_{1}$ horizon of a gray-brown podzolic soil correlated with rainfall from southwesterly subtropical air masses originating over the sea and from nor thwesterly continental air masses travelling over the Great Lakes, respectively. In eastern North America, where the prevailing winds are generally seaward, less chloride appears to be carried inland than in western Europe, where the prevailing winds blow toward the land. ( $C f$. Junge and Gustafson, 1957, Fig. 3, p. 166.)

Salt lakes subject to drying may show another effect of wind. Hutton (1958, p. 289) has suggested that certain such lakes in Australia contain far less salt than might be expected from the annual accessions in rain; he postulates considerable losses owing to deflation during periods when the lakes are dry and dusty. Hutchinson (1957, p. 564) notes the possibility of similar losses in the Lahontan basin of western North America.

A different effect of wind upon lakes is its action in breaking down thermal stratification, allowing mixture of enriched bottom water with the more dilute overlying layers. In addition to autumnal cooling, stormy weather with gales and floods frequently assists in bringing an end to stratification of lakes in the English Lake District.

Atmospheric turbulence other than wind may also affect the ionic composition of rain. Junge and Gustafson (1957, p. 167) have invoked large-scale vertical mixing over continents to account for the rapid decrease of chloride in rainfall and in lake and stream waters with increasing distance from the sea coast. This is in contrast to the usual hypothesis that most of the chloride is washed out of the air by rains in the coastal regions, leaving less to be washed out later inland. Over the sea most of the salt is concentrated in the lower part of the troposphere and decreases rapidly above cloud base. Over the land convective mixing is much more active, and the sea-salt particles become dispersed throughout a much taller column of air, so that in the lower layers of the troposphere where most rain develops there are far fewer salt particles available for precipitation. (Cf. also Twomey, 1955, p. 84.)

Additional climatic effects are discussed in a following section on the time factor.

\section{Geology}

Although considerable attention has been paid to atmospheric accessions of salts, it must be emphasized that soil and rock weathering provides the major supply of ions to natural waters. Durum's (1953) demonstration that a ground-water contribution of only 35 per cent total stream discharge supplied 76 per cent of dissolved solids in the waters of the Saline River in Kansas is a good illustration of this, a situation reasonably typical of sedimentary deposits in the central United States.

Although soils and rocks serve mainly as a source of minerals to ground water, local geology also influences the chemistry of raindrops in the air. The amounts of calcium and potassium contributed to rain by soil dust depend on the nature of the local soils. Rain in the English Lake District, a region of volcanic or slaty rocks, normally contains only about 0.3 ppm of calcium (Gorham, 1955b, p. 236), whereas in a part of western Ireland where limestones are abundant there may be five times this concentration (Gorham, 1957a, p. 2).

The influence of geology upon the composition of lake and river waters has already been dealt with in its general aspects, as outlined by Conway (1942), and numerous local investigations were discussed in detail by Clarke (1924). Clarke also summarized (p. 161) the different geological conditions in which alkaline and saline lakes are formed in closed basins-the former ordinarily characterizing areas of igneous rocks and the latter sedimentary deposits.

Mackereth (1957) and Gorham (1958a, p. 172) showed that on the volcanic rocks making up the central mountains of the English Lake District the waters are very dilute, approximating the composition of rain water plus a little calcium, magnesium, and bicarbonate weathered from the rocks and soils. On the Silurian slates and flags of the southern part of the district soil-derived bicarbonates become much more important, and appreciable amounts of potassium and sulfate are also supplied from the soil, so that the lake waters are considerably more concentrated. On the easily weathered sedimentary rocks of the Triassic and Carboniferous periods, around the periphery of the 
Ir layers

Mevelops

hble for

p. 84.)

sed in a

been

it must

thering

natural

that a

er cent

cent of

Saline

this, a

nentary

ly as a

local

of rain-

im and

lust de-

in the

anic or

out 0.3

236),

re lime-

times

\section{2).}

mposi-

y been

ined by

vestiga-

(1924).

ifferent

he and

hs-the

of igne-

posits.

58a, p.

making

h Lake

pproxi-

plus a

rbonate

On the

part of

become

mounts

d from

derably

athered

arboni-

of the
I he I wrin, hake waters are still more concen$11.11+1$ ind strongly calcareous. In these waters Im, if the calcium, about 80 per cent of the m.4n:usimu, more than half the potassium, and $\left.|"|\right|_{1,1} \mid$ : anc-third the sulfate is supplied by wanlinging. Chloride and sodium in this .11. won still to be almost wholly supplied by if ymay carried down in the rain, and their m winc in concentration moving outward from $1 / 4+111,1$ mountains is probably due to lower 1.111.4ll and greater evaporation in the lowlinkls.

Rakk mincralogy may be an important factor p. 100-101) in contrast to an average of about 17 in the Swedish limestone lakes of the Siljan district (Lohammar, 1938; Gorham, 1955a, p. 134). Similarly the calcium/magnesium ratios of Wisconsin lake waters are only about 2; magnesian limestone and dolomite contribute cxtensively to the soils in their drainage basins (Hutchinson, 1957, p. 555). Triassic substrata in Shropshire also release large quantities of calcium and bicarbonate to the lake waters draining them, which however differ from those of limestone lakes in containing an abundance of other salts, and in their cxcep-

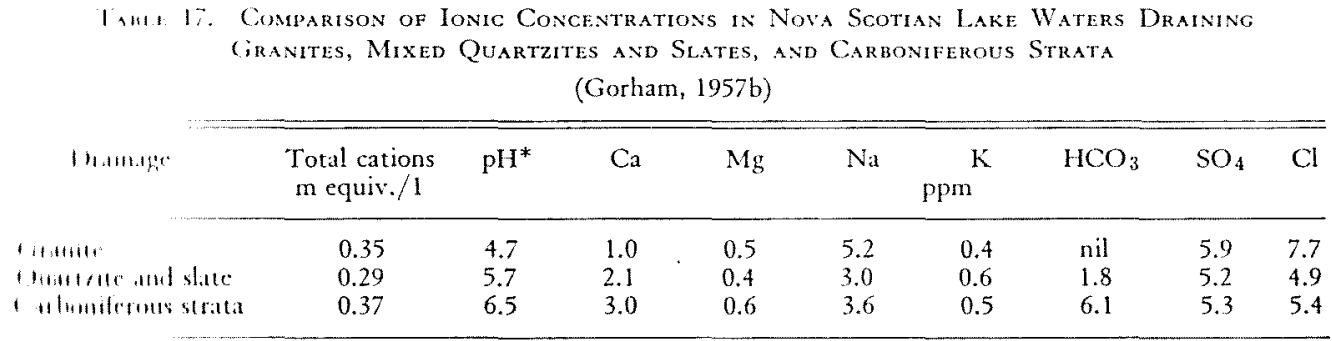

- Aithuntir average of values before aeration

111 IIInctal supply. For instance, the volcanic nuk w llic central Lake District are not Iininlily poor in lime (Guppy, 1931; 1956), but it if not casily released. Pearsall $(1921 ; 1929)$, in lividing the English Lakes for ecological 1uifurse into rocky and silted types, recognized Hing fiactor.

More frequently of importance is the relative Anumbunce of different elements in various wher. This effect of geology is clearest in deepwell waters that have had a long time to ryuilibrate (sec extensive data summarized by Ihrosh, Beile, Suckling, and Taylor, 1949; 11.11, 1959), but is also evident in surface witw limestone influence upon water compoattini is particularly striking, for where it is 1"16ul like and river waters are as a rule 114+11y cmiched in calcium and bicarbonate inil ligure 1 illustrates this clearly in the case in Swodish lake waters, and Kobayashi (1955) lus huwn similar enrichment in comparing lapances rivers draining eruptive volcanic iii is with those draining Paleozoic rocks with Immrthme. Many alpine lakes in Bavaria and Aushin receive calcareous drainage, but owing 111 He prevalence of dolomite the calcium/ mapnisimu ratio (by weight) of the lake waters nuger ilbut 4 (see Clarke, 1924, table on tional potassium concentrations (Gorham, 1957d, p. 178).

Further examples of the general correlation between geology and water chemistry have been provided by Möller's $(1949$; 1955) extensive investigations of the dissolved substances in German waters, summarized by concentration maps.

In regard to anions other than bicarbonate, Beauchamp (1953) remarks the importance of sedimentary rocks for sulfate supply and notes that their absence is at least partly responsible for the general dearth of sulfate in East African waters. The influence of sedimentary deposits on the chloride content of inland waters was stressed by Clarke (1924, p. 161), and Eriksson (1955) recorded very high chloride discharges by North American rivers associated with salt domes.

Considerable difference is found in ionic composition of dilute Nova Scotian lake waters on granites, mixed quartzites and slates, or on Carboniferous strata (Table 17). Whereas all the waters are low in salts, those on granite are peculiarly low in lime and are strongly acid. This is counterbalanced by higher sodium levels, since the granite lakes are closest to the sea. The old analyses by Hanamann (Clarke, 
1924, table on p. 104), recalculated for Table 18, show that Bohemian stream and river waters draining phyllite, granite, mica schist, basalt, and Cretaceous sedimentary deposits exhibit increasing salt content in that order. Comparable data for some streams in Wyoming and Montana are presented by Swenson (1953). There, waters on granite are dilute $(43 \mathrm{ppm}$ total solids) and dominated by calcium and bicarbonate, whereas the waters on limestone are nearly four times richer in solids but are still dominated by the same ions. On gypsum, still more concentrated waters occur $(727 \mathrm{ppm}$ total solids), with calcium and sulfate abun- effects upon water composition. In western Ireland the schists of Connemara are occasionally banded with limestone, which may raise the calcium concentration in neighboring waters appreciably (Gorham, 1957e, p. 241). Even more locally, Macan (1950) noted the influence of limestone bands upon water chemistry in different parts of the same small lake, whose inflows ranged in calcium concentration from 3 to $26 \mathrm{ppm}$. Local mineral springs are often responsible for enrichment of lake waters in sodium chloride (Clarke, 1924, p. 101), while local deposits of gypsum may add calcium sulfate (Clarke 1924, p. 100).

Table 18. Composition of Bohemian Waters Draining Various Geologrcal Substrata (ppm) (Clarke, 1924)

\begin{tabular}{lrrrrrrr}
\hline Substratum & $\mathrm{Ca}$ & $\mathrm{Mg}$ & $\mathrm{Na}$ & $\mathrm{K}$ & $\mathrm{HCO}_{3}$ & $\mathrm{SO}$ & $\mathrm{Cl}$ \\
\hline Phyllite & 5.7 & 2.4 & 5.4 & 2.1 & 35.1 & 3.1 & 4.9 \\
Granite & 7.7 & 2.3 & 6.9 & 3.7 & 40.3 & 9.2 & 4.2 \\
Mica schist & 9.3 & 3.8 & 8.0 & 3.1 & 48.3 & 9.5 & 5.4 \\
Basalt & 68.8 & 19.8 & 21.3 & 11.0 & $326.7^{*}$ & 27.2 \\
Cretaceous rocks & 133.4 & 31.9 & 20.7 & 16.4 & $404.8^{*}$ & 167.0 & 17.3
\end{tabular}

* Presumably occurs partly as $\mathrm{CO}_{3}$

dant, but the richest waters are those on shale (2020 ppm total solids), in which alkalies and sulfate predominate. Troedsson (1952) has made a somewhat similar comparison of Swedish ground waters, data for which are given in Table 19. These show the importance of Cambro-Silurian limestone in adding calcium and potassium to Swedish waters (see also Fig. 1) and the extreme scarcity of these ions in waters draining fluvioglacial sands.

Some influence of soil texture upon water chemistry has been suggested by Gorham (1957d, p. 178) to account for greater salt concentrations in Shropshire lake waters on Triassic sands and gravels than in those on Triassic boulder clay. Presumably the coarse deposits allow deeper percolation and hence more effective leaching of these relatively rich soils, whereas surface runoff is more favored by the boulder clays. Another example is given by Ruttner (1953, p. 57), who remarks that, in the northern approaches to the Alps, springs from lime-poor impermeable soils derived from igneous rocks are richer in calcium than are those from limestone areas in the mountains, where the rain drains rapidly through the permeable rock and has little opportunity to be charged with carbon dioxide in the surface soil.

Subsidiary rocks may have marked local
An interesting case of local geological influence has recently been discussed by $G$. C. Anderson (1958, p. 259), who quotes the views of O. P. Jenkins on the formation of the shallow and strongly saline Hot Lake in north-central Washington, U.S.A., an area of metamorphic rocks, dolomites, and shales. Near the lake are numerous bodies of oxidized pyrite and pyrrhotite, and it has been inferred that during oxidation considerable sulfuric acid was generated and acted upon the dolomitic and other rocks to form soluble magnesium sulfate and the relatively much less soluble calcium sulfate. The magnesium sulfate would be carried into the lake, together with a little calcium sulfate, but the latter would soon precipitate as gypsum and be covered by deposits of epsomite as evaporation led to continual concentration. Mining operations have in fact revealed beneath the lake bottom a 5-meter layer of cpsomite, separated from the bedrock by thin layers of gypsum and clay. At present magnesium and sulfate predominate in the strongly saline waters, and calcium is very low proportionately.

Attempts have frequently been made to estimate the relative mobility of elements in the cycle of weathering, by comparing the composition of unweathered rocks with that of 
the waters draining away their weathering products

(relative mobility $=\frac{\% \text { of element in water }}{\% \text { of element in rock }}$.

Smyth (1913) and Polynov (1937, p. 162) were early exponents of the method; later Reiche (1942) and Anderson and Hawkes (1958) applied it to local situations and used the results as evidence that the mobility of different elements varies greatly from one site or rock type to another. Unless a correction for cyclic climatic modification. Effects of altitude upon moisture balance, and hence upon ionic concentration, have been noted for Swedish, Norwegian, and Scottish lake waters. The rise of chloride levels in waters progressively nearer the sea is a more direct effect. Early American work on this subject is cited by Clarke (1924, p. 56), and later data are given for Japanese and English lake waters by Yoshimura (1936) and Gorham (1958a, p. 171). Gorham and Cragg (1960, p. 177) provide some data for bog waters, and Eriksson (1955) shows maps of

Table 19. Analyses of Swedish Ground Waters on Different Substrata

(Troedsson, 1952)

\begin{tabular}{|c|c|c|c|c|c|c|}
\hline Substratum & Soil & $\begin{array}{l}\text { Specific } \\
\text { conductance, } \\
\text { micromhos } \\
\text { at } 20^{\circ} \mathrm{C}\end{array}$ & $\mathrm{Ca}$ & $\begin{array}{l}\mathrm{Mg} \\
\text { ppm }\end{array}$ & $\mathrm{Na}$ & $\mathrm{K}$ \\
\hline Sandstone moraine & Iron podzol & 16 & 2.3 & 0.5 & 2.6 & 1.1 \\
\hline Porphyry moraine & Iron podzol & 31 & 2.9 & 0.3 & 2.7 & 1.5 \\
\hline Leptite gneiss moraine & Iron podzol & 32 & 3.0 & 1.3 & 2.8 & 0.4 \\
\hline Fluvioglacial sand & Iron podzol & 42 & 1.7 & 0.5 & 5.4 & 0.4 \\
\hline Dolerite moraine & Iron podzol & 46 & 5.0 & 0.8 & 4.2 & 1.0 \\
\hline \multirow{2}{*}{ Leptite gneiss moraine } & Iron or humus podzol & 59 & 5.6 & 1.0 & 3.7 & 0.7 \\
\hline & $\begin{array}{c}\text { Wave-washed gravel } \\
\text { over glacial clay }\end{array}$ & 115 & 11.2 & 3.4 & 5.3 & 0.7 \\
\hline $\begin{array}{l}\text { Archaean noraine with } \\
\text { Cambro-Silurian admixturc }\end{array}$ & Brown earth & 420 & 79.5 & 4.2 & 9.3 & 3.2 \\
\hline
\end{tabular}

atmospheric salt is applied, however, erroneous results may be obtained, especially with regard to chlorine and sulfur (Gorham, 1955a, p. 135). In maritime areas sodium and to some extent magnesium mobility may be considerably overestimated. Long-distance aerial transport of dust can also introduce errors, especially in very dilute waters. For instance, the New England precipitation analyses of Junge and Werby (1958) show amounts of sodium, potassium, and calcium that could provide appreciable fractions of the concentrations of these same ions in the New England streams studied by Anderson and Hawkes (1958), especially if the values could be corrected for evaporation. Differential capture of aerial salts by vegetation (Eriksson, 1955; Tamm, 1953, p. 88; Madgwick and Ovington, 1959, p. 17) may also influence such calculations to a degree that is difficult to assess.

\section{Topography}

The influence of topography upon water chemistry is often indirect, acting through chloride discharge for Swedish and American rivers. Chloride gradients in rain from various parts of the world have been observed by Leeflang (1938), Hanya (1951, p. 4), Emanuelsson, Eriksson, and Egnér (1954, p. 262), Junge and Gustafson (1957, p. 165), Eriksson (1958, p. $151 ; 1960$, p. $81,87-89)$, and Hutton and Leslie (1958, p. 503). Squires and Twomey (1957) give evidence for the effectiveness of orographic rain in washing sea-salt particles from air moving upslope in Hawaii. (See also Woodcock, 1953, p. 370.) Eriksson (1958, p. 151) has noted the importance of land form in controlling coastal chloride gradients, which are more pronounced where the land rises steeply from the sea.

Proximity to the sea has also led to temporary marine submergence of many lakes in peculiar topographical situations. Hutchinson (1957, p. 482 ff.) considers several examples where more or less distinct saline water masses persist beneath surface layers of fresh water (ectogenic meromixis). The submergence of much of the Swedish province of Uppland at 
the end of the ice age is probably responsible for high chloride levels persisting in the lakes nearest sea level. (Cf. Lohammar, 1949.) It is also responsible for the richness of most of the Uppland lakes in calcium and bicarbonate, since layered clays and submarine marls are abundant east of a line from Gävle to the tip of Mälaren (Lunquist, 1935 , p. 293). The lakes around Stockholm, a little to the south, are not so rich (Puke, 1949), presumably because of the lesser deposition of marl there (Gorham, 1955a, p. 142).

Another consequence of the submergence and later uplift of the Fennoscandian land mass was the establishment and subsequent drainage alkaline waters in seepage lakes without them. Evaporation is presumably the main concentrating factor in these seepage lakes.

The above examples contrast with the situation in Wisconsin, where seepage lakes are exceptionally dilute, because they collect mainly surface runoff and do not become greatly concentrated by evaporation. A similar phenomenon has been examined by the writer in Epping Forest near London, England. Two small ponds near Baldwin's Hill provide a sharp contrast in location; one (B) is situated on clayey soil in a small valley with a stream running through it, and the other (A) occupies a small hill near by and exhibits no visible inflow

Table 20. Water Analyses from a Seepage and a Drainage Pond in Epping Forest near London, England (ppm)

\begin{tabular}{lccrrrrrr}
\hline \hline & $\mathrm{Ca}$ & $\mathrm{Mg}$ & $\mathrm{Na}$ & $\mathrm{K}$ & $\mathrm{HCO}_{3}$ & $\mathrm{SO}_{4}$ & $\mathrm{Cl}$ & $\mathrm{SiO}_{2}$ \\
\hline (A) Seepage pond & 4.0 & 3.1 & 4.8 & 3.5 & 14.6 & 8.6 & 12.1 & 0.4 \\
(B) Drainage pond & 45.4 & 33.2 & 24.2 & 4.7 & 119.0 & 144.0 & 44.4 & 8.0 \\
B/A & 11 & 11 & 5.0 & 1.3 & 8.2 & 17 & 3.7 & 20 \\
\hline
\end{tabular}

of many aquatic areas, which developed gytija types of sediments rich in various forms of sulfur. This sulfur enrichment has led to extreme acidity in such soils following cultivation, which by improving aeration allows oxidation to build up very high concentrations of sulfuric acid. Wiklander and his associates (1949; 1950a) have studied such gyttja soils, and Kivinen (1955) gives several analyses of the water-soluble salts present in them. Somewhat similar types of acid soil are found along the edges of drained swamps in Uganda (Chenery, 1953), where however there is no history of marine submergence. There sulfur reaches the swamps as sodium sulfate, derived from soda-rich minerals in the surrounding hills, which are weathered by sulfuric acid from oxidizing pyrite deposits.

Hutchinson, Wollack, and Setlow (1943) remark that absence of outlet streams may have a marked influence upon the chemistry not only of lake waters but of lake sediments in Indian Tibet. There the closed basins contain waters greatly enriched in magnesium, and in some cases calcium, while their sediments are also high in both these elements. Studies by Böcher (1949) in Greenland and Rawson and Moore (1944, p. 148) in Saskatchewan show a similar contrast between dilute waters in drainage lakes with outlets, and rather saline and or outflow except in time of floods. The seepage pond (A) appears to derive most of its water supply from surface runoff, whereas the drainage pond (B), with a large amount of dissolved silica in its water, undoubtedly receives deep subsoil water via its inflow stream. Analytical data for the two waters are given in Table 20, and it is evident that the deeper soil drainage adds large amounts of salts as well as silica to the water of pond (B); sulfates and alkaline earths are raised most markedly.

The Cheshire meres in England (Gorham, $1957 \mathrm{c}$ ) provide another example. Table 21 compares average ionic proportions of seven normal drainage lakes in Cheshire with those of one small and one large seepage lake, and with the ionic proportions of rain from the Lake District to the north, which are probably not greatly different from those in Cheshire rain. It appears that the small lake contains essentially strongly evaporated rain water, whereas in the larger seepage lake a good deal of calcium and magnesium has been added, presumably because of exchange of hydrogen ions in rain for alkaline earth cations adsorbed on soil colloids. Normal Cheshire meres receiving stream drainage from deeper horizons of the soil show this process of calcium addition carried much farther, to the point of producing distinctly alkaline waters. A somewhat similar

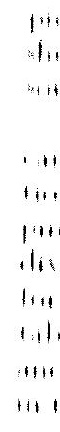

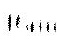

$14+1$

"n

Win

sit

$1+1,20$

lini"

lin!n:

tin,

Hinit

Hin+m,

bulls

lis $y$

11

min!:

hise.

11111,

$1,4,1$

(")

111

biljin

limit.

in sis

liigli i

1111

$4: 11$

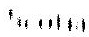

stion

if $1 / 1$

hinll.

I whe

Hhath

$4+41$, 
picture of progressive calcium addition is shown by the Shropshire meres a little to the south (Gorham, 1957d).

In arid areas the depth to the water table can exert a great infuence on water composition. Reservoirs in the plains of Colorado, tapping streams from the mountains, may be divided into alkali and nonalkali waters, the former occupy depressions with high water tables and contain about 2-3 times the calcium and 8-9 times the total mineral material found in the latter (Pennak, 1958). Even in relatively colonization by higher plants; the concentrations are also more variable in these later stages. From the Nova Scotian study it also appears that the browner waters in peaty surroundings exhibit low pH values (minimum 4.5), owing to the presence of free sulfuric acid. In this area of base-deficient soils the distribution of peat is controlled largely by topographical factors.

The size and shape of a lake basin may affect the chemistry of its water. From the data on lakes in Scotland (Fig. 3) it is quite apparent

Table 21. Ionic Proportions in Cheshire Meres and Lake District Rain

(Gorham, 1957c)

\begin{tabular}{|c|c|c|c|c|c|c|c|c|c|c|}
\hline \multirow{2}{*}{$\frac{\text { Sample }}{\text { Rain water }}$} & \multirow{2}{*}{$\frac{\mathrm{pH}}{4.5}$} & \multirow{2}{*}{$\frac{\begin{array}{c}\text { Total } \\
\text { salts } \\
\text { m equiv./1 }\end{array}}{0.17}$} & \multirow{2}{*}{$\begin{array}{l}\mathrm{H} \\
26\end{array}$} & \multirow{2}{*}{$\frac{\mathrm{Ca}}{\mathrm{n}}$} & $\begin{array}{l}\mathrm{Mg} \\
\text { Miv. }\end{array}$ & $\mathrm{Na}$ & $\mathrm{K}$ & $\begin{array}{l}\mathrm{ICO}_{3} \\
\text { hions }\end{array}$ & \multirow{2}{*}{$\frac{\mathrm{SO}_{4}}{42}$} & \multirow{2}{*}{$\begin{array}{r}\mathrm{Cl} \\
58\end{array}$} \\
\hline & & & & & 10 & 52 & 3.1 & nil & & \\
\hline $\begin{array}{l}\text { Water from small } \\
\text { seepage lake }\end{array}$ & 3.9 & 0.55 & 24 & 16 & 13 & 42 & 5.5 & nil & 49 & 51 \\
\hline $\begin{array}{l}\text { Water from large } \\
\text { seepage lake }\end{array}$ & 4.7 & 1.05 & 1 & 36 & 20 & 37 & 5.7 & nil & 51 & 48 \\
\hline $\begin{array}{l}\text { Water from seven } \\
\text { normal drainage } \\
\text { lakes }\end{array}$ & $\begin{array}{l}7.3 \text { to } 8.6 \\
\text { (4 samples) }\end{array}$ & 4.53 & nil & 54 & 27 & 17 & 2.4 & 48 & 33 & 18 \\
\hline
\end{tabular}

humid regions lesser effects may be discerned, for example Troedsson (1955, p. 179) observed that beneath normal forest in middle Sweden ground water is somewhat poorer in dissolved salts than beneath peaty depressions occupied by Sphagnum moss (Table 14).

The nature of the relief frequently determines patterns of sedimentation, which may have marked local effects on water chemistry. In the Swedish province of Dalarna, lakes on Dalälven river sediments are unusually rich in calcium and bicarbonate (Gorham, 1955a, p. 133; see also Fig. 1); the source is presumably Siljan limestone drift deposited in late glacial times. The peculiar composition of the waters in Swedish esker lakes, with their uncommonly high proportions of potassium (Gorham, 1955a, p. 134), has also been remarked.

Senescent lakes in Halifax County, Nova Scotia, so situated as to be almost filled by sediments, contain about twice as much calcium in their waters as do normal lakes there (Gorham, 1957b, p. 16). Similarly, from the English Lake District Macan (1950, p. 134) records greater calcium and bicarbonate levels in the waters of tarns in a more advanced stage of that lower chloride concentrations are found in in the larger lakes at a given altitude. This is due not only to the relatively lesser degree of evaporation from these lakes with smaller area/volume ratios, but also to the reception by the larger lakes of a good deal of water from streams draining upland gathering grounds, where evaporation is again less intense. The effect of lake depth upon chloride is illustrated by the data of Yoshimura (1936, p. 348), which show that in Japan, at comparable distances from the sea, the very shallow dammed lakes of Nakakubiki exhibit distinctly higher concentrations than the much deeper crater lakes of Oga. Another example of depth effects is given by Rawson and Moore (1944, p. 149), who find that rates of salinization in some Saskatchewan lakes are related to their mean depths; the rate is less than half as rapid in lakes of $10-15 \mathrm{~m}$ mean depth as in those about 1-2 in deep.

The size of bog pools, which determines whether or not they are subject to much drying in summer, affects both concentration and ionic balance in British bog waters (Gorham, 1956b, p. 379). The concentration of sulfuric acid in- 
creases greatly in the smaller pools during dry periods, owing partly to evaporation but mainly to greater aeration of the peat, and consequent oxidation of sulfur compounds. This increase in acidity leads to exchange of hydrogen ions for metal ions adsorbed on the peat colloids, as mentioned previously, so that sodium/chloride and especially magnesium/ chloride ratios increase greatly in the smaller pools. In large permanent bog pools of the Falkland Islands (Gorham and Cragg, 1960, p. 178), some of the sulfate supplied in sea spray may be reduced to sulfide, thus lowering sulfate/chloride ratios below that of sea water; in smaller pools subject to drying, sulfate is considerably enriched, as it is in Britain.

The balance of ions in stratified bottom waters of lakes may be influenced by the shape of the basin, as a comparison of two English lakes shows (Mortimer, 1949). Esthwaite Water, being relatively shallow, becomes anaerobic below the thermocline in summer, while the deep lake Windermere does not. Whereas bottom waters of Windermere exhibit little seasonal change in ionic composition, those of Esthwaite show a marked rise in bicarbonate and fall in sulfate during summer; both effects disappear at the autumnal overturn when isothermal circulation is restored. Hutchinson $(1957$, p. 675) believes that changes in the slope of the bottom in Linsley Pond, Connecticut, may account for the somewhat irregular vertical distribution of bicarbonate in the lake water during summer stratification.

Some lakes are so large that they contain distinct water masses of different chemical composition, fed by rivers from different parts of the drainage basin, or restricted in circulation and mixing by local topographic barriers or shape. The wide variations in salinity of different parts of the Caspian Sea are classic (e.g. Clarke, 1924, p. 168), and Ayers et al. (1956) have demonstrated very much smaller but consistent differences in salinity of Lake Huron water masses originating from Lake Superior and Lake Michigan, respectively. Great Slave Lake provides a notable example of isolated and chemically different water masses within one lake (Rawson, 1950). Water from McLeod Bay of Great Slave Lake contains only $23 \mathrm{ppm}$ of total solids and $3 \mathrm{ppm}$ of calcium, although the main lake water contains 160 and $31 \mathrm{ppm}$ respectively. Likewise chloride and sulfate are negligible in McLeod Bay, but the main lake waters contain 12 and 25 ppm respectively. The main lake drains a variety of geological formations, some of them easily weathered and rich in lime and other salts, but McLeod Bay receives only rivers of basedeficient Precambrian rocks, and these develop such a strong flow into the main lake that there is little mixing of the two types of water within McLeod Bay itself. These spatial variations in the chemical composition of water masses within large lakes are analogous to the variations at different points in large rivers owing to chemical differences in successive inflows. Good examples of the latter are given by Clarke (1924, p. 69).

To conclude discussion of the topographical factor, an interesting reverse effect of water chemistry upon lake shape may be mentioned. Hooper $(1956$, p. 121) noticed that in a series of 27 thermally stratified and calcareous Michigan lakes the alkalinity of the waters is strongly correlated with the mean slope of the basins between the 5 - and 25-foot contours $(r=+$ 0.74). This he interpreted as due to progressively greater calcium carbonate deposition in lakes of higher alkalinity, producing shallow marl benches with a steep marginal drop to deep water.

\section{Biology}

Organisms can have a profound influence upon the circulation of elements through natural waters. However, since their distribution is generally conditioned by the environment, it is difficult to find instances where the biotic factor operates independently to control the chemical composition of waters. That is, one can seldom identify primary differences in flora and fauna as responsible for differences in the chemistry of natural waters situated in the same physicochemical environment, except in cases of human interference.

Organisms frequently remove large quantities of the major ionic constituents from waters. Some figures are given in Table 22 for annual mineral uptake (as kilograms per hectare per year) by forests and crops in the temperate zone, and these are compared with data on atmospheric supply and on soil drainage. Such a table does not permit detailed interpretation, but it does show that the quantities of minerals cycled through vegetation are often similar to or greater than the supply by atmospheric precipitation, and may even amount to an appreciable proportion of the quantity carried away by rivers (which of course is removed after plants have fulfilled their requirements). Plant demand for calcium and potassium is

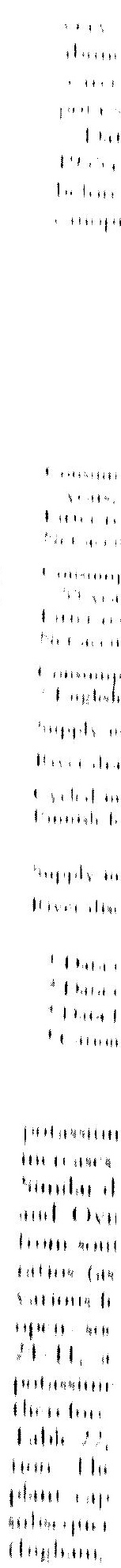


very high, but whereas calcium is relatively abundant in most natural waters, potassium is scarce, and a great part of the total available potassium may circulate through vegetation.

Data of Tamm (1953, p. 88; see also Gorham, 1955a, Table 2, p. 138) on rain composition before and after percolation through forest canopies indicate an 18-fold enrichment of and Sugavara, 1953; Eriksson, 1955, p. 245). Stenlid (1958) has reviewed the subject of leaf excretion in detail.

Considerable release of mineral elements from forest vegetation also takes place during leaf fall in autumn. Table 22 shows that a large part of the alkalies and alkaline earths taken up by pine or birch forest is returned to the

Table 22. Consumption of Mineral Elements by Vegetation, Compared with Amounts Supplied in Precipitation and Carried by Rivers $(\mathrm{kg} / \mathrm{ha} / \mathrm{yr})$

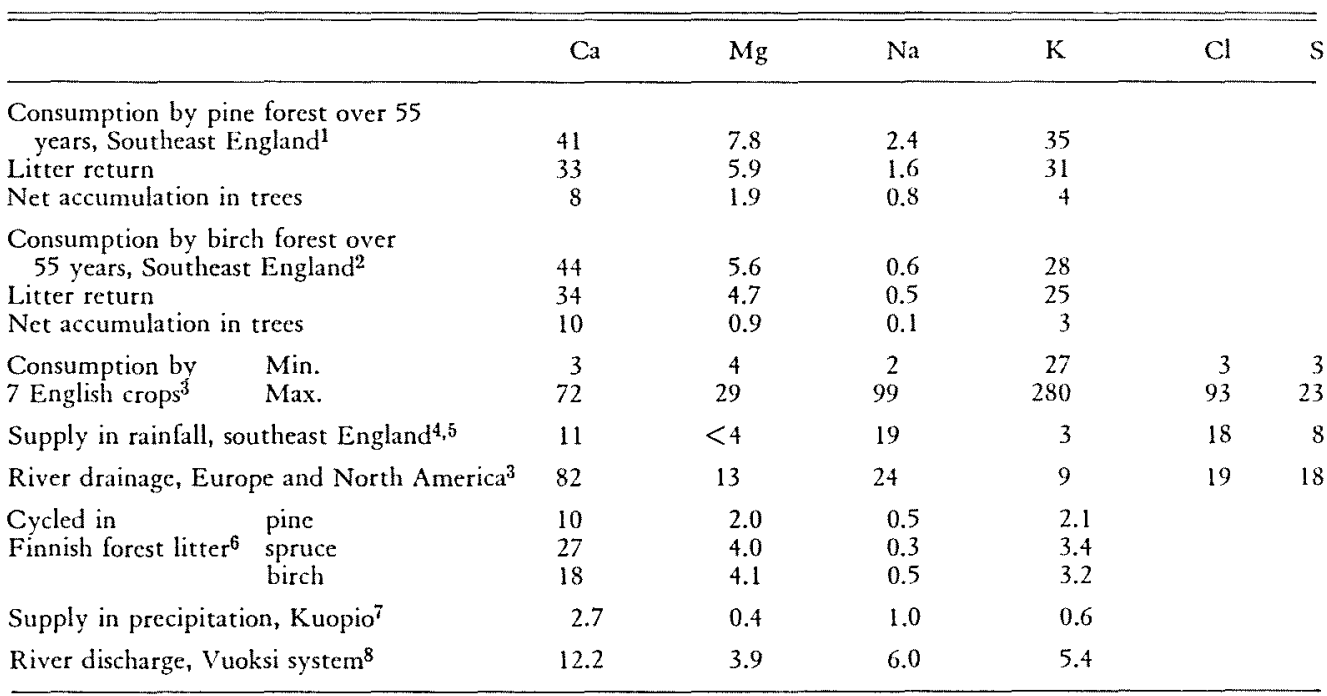

1 Data of Ovington (1959)

2 Data of Ovington and Madgwick (1959)

${ }^{3}$ Data from Russell (1950)

${ }^{4}$ Cation data of Madgwick and Ovington (1959)
${ }^{5}$ Anion data from Eriksson (1952), for Rothamsted 6 Data of Viro (1955)

${ }^{7}$ Data from quarterly appendices to Tellus

${ }^{8}$ Data of Viro (1953) potassium as compared with 4-fold and 3-fold increases in calcium and sodium respectively. Similar data have been provided by Madgwick and Ovington (1959, p. 17), whose analyses from southeastern England show the following ratios (as $\mathrm{kg} / \mathrm{ha} / \mathrm{yr}$ ) of rain-water ions under various forest canopies to rain-water ions in the open: sodium 33/19, potassium $24 / 3$, calcium $24 / 11$, and magnesium $10 /<4$. The actual potassium circulation through vegetation may therefore be much greater than estimated from Table 22, which takes no account of leaf excretion. The question is further complicated by plant capture of aerosols from dry air, which subsequently release salts when leached by rain (Ingham, 1950; Sugawara, 1951, p. 14; Koyama soil in this way (Ovington, 1959; Ovington and Madgwick, 1959); extensive data on nutrient content of forest litter confirm its importance (Stenlid, 1958, p. 625). Curiously, Table 22 indicates that Finnish forest litter is much poorer in potassium than English litter.

Joffe (1933), in an investigation of water percolating through the $A_{1}$ horizon of an immature podzol beneath forest, demonstrated a marked rise in $\mathrm{pH}$ and specific conductivity during autumn, when leaf fall is greatest. The $\mathrm{pH}$ rose from a normal level of 4.8 to as much as 6.4 ; specific conductivity (a function of total dissolved ions) increased up to four-fold. According to Viro (1955), most of the potassium and roughly half the magnesium in 
Finnish forest litter is leached out within a year, while only a small part of the calcium is released during this period.

The importance of sulfur release from dead plant material, partly as sulfuric acid, has already been stressed in the discussion of soil weathering. Unfortunately few quantitative data exist for the circulation of sulfur in vegetation. Table 22 gives a range of crop consumption from 3 to $23 \mathrm{~kg} / \mathrm{ha} / \mathrm{yr}$, and Stenlid $(1958$, p. 625) quotes a return in forest litter of between 1 and $5 \mathrm{~kg} / \mathrm{ha}$ annually.

So far only uptake by terrestrial vegetation has been considered. Lund (1957) examined the concentrations of various elements (including calcium, magnesium, potassium, sulfur, and carbon) in the maximum observed phytoplankton crop from a soft-water lake (Windermere) and reported that the amounts of these elements sequestered in phytoplankton amount to no more than a small fraction of the total dissolved in the lake water. However, Beauchamp (1953) believes that in large African lakes the extremely low levels of sulfate in surface waters are due to uptake by plankton, which sediments eventually to the bottom, where its sulfur is trapped in the mud. Such a process may also be important in Swedish seepage lakes (Gorham, 1955a, p. 140). The influence of rooted vegetation in lakes, and especially in small ponds, has not been examined in this way, and complete analyses are scanty. Welch (1935, Table 31, p. 281) quotes some data on the chemical composition of higher plants from Wisconsin lakes.

Animals also withdraw elements from natural waters. Formation of calcareous shells by mollusks may sometimes be of considerable importance, and the lower level of calcium in Lake Tanganyika than in its inflows has been explained by Beauchamp (1939) as at least partly due to molluscan removal.

Return of minerals to lake waters through decomposition of organic materials deposited in the sediments is probably greater in lakes rich in lime and other nutrients. According to Hayes and Anthony (1958, p. 305) the ignition loss of sediments is inversely related to the $\mathrm{pH}$ of waters in Nova Scotian and Wisconsin lakes, suggesting greater microbiological breakdown of sedimenting organic detritus in the more fertile lakes.

Apart from direct consumption, plants and animals affect the distribution of major ions in waters indirectly in various ways; perhaps the best known is the precipitation of calcium carbonate marls. Welch (1935, p. 177) gives many examples of marl-forming plants, which by photosynthetic utilization of dissolved carbon dioxide have produced calcium carbonate in excess of the amount soluble. According to Ohle (1934), as quoted by Hutchinson (1957, p. 670), many hard-water lakes may be supersaturated with calcium carbonate, which in surface waters equilibrated with normal atmospheric carbon dioxide pressures would be soluble to the extent of about 65-74 ppm (equivalent to 26-30 ppm of calcium and 79-90 ppm of bicarbonate ion). Much greater concentrations frequently occur in hard surface waters; the excess is presumably in stable colloidal form.

Marl precipitation seems to be favored in waters with low rates of detrital sedimentation. Organic decomposition must be insufficient to generate large quantities of carbon dioxide in the bottom waters and muds; otherwise the marl would redissolve there. In many productive English lake waters very high concentrations of calcium and bicarbonate are present without quantitatively significant precipitation of marl. On the other hand Hooper (1956, p. 122) found that in one group of stratified lakes in Oakland County, Michigan, the formation of marl benches begins to be extensive when bicarbonate alkalinity reaches about $105 \mathrm{ppm}$, not far above the level reported for calcium carbonate saturation.

In the English Lake District marl lakes are rare, although Sunbiggin Tarn, on the periphery of the district and fed by limestone springs, provides an example. This lake has water with $47 \mathrm{ppm}$ of calcium and $142 \mathrm{ppm}$ of bicarbonate (Holdgate, 1955, p. 403, analyses by Gorham). Dr. J. W. G. Lund (oral communication, 1958) observed incipient precipitation of calcium carbonate in a quarry pool at Brathay, where calcium and bicarbonate concentrations of 37 and $78 \mathrm{ppm}$ respectively were recorded.

Malham Tarn in Yorkshire, south of the Lake District, is another hard-water lake with a complicated history. Table 23 shows analyses (Gorham, 1961) of water from the main inflow and the lake itself, and also the ratio of lake to inflow concentrations. First may be noticed a general reduction of concentration in the lake waters, probably owing to dilution by unevaporated surface runoff; this is illustrated by the chloride ratio of 0.82 . Secondly, however, there is a marked reduction of calcium and bicarbonate concentrations; the 
ratios are only 0.59 and 0.60 respectively. This may be due partly to accessions of limedeficient surface runoff, but calcium carbonate precipitation is probably involved as well, since sediment cores reveal marl deposits throughout the greater part of the lake's history. In the recent past, however, much acid peat has been eroding into the lake from an adjacent raised bog; it may react with calcium and bicarbonate or carbonate, adsorb calcium in exchange for replaceable hydrogen ions, and release water and carbon dioxide. (Cf. Ohle, 1955b.)

To illustrate the isolating effect of a blanket studying lakes he carried out experiments on aerobic and anaerobic mud-water systems in tanks, which provided closed systems and at the same time simulated lake conditions to some degree. Mortimer found that in the aerobic tank sulfate was liberated from the mud in to the water, but in the anaerobic tank sulfate in the water was reduced and eventually precipitated as ferrous sulfide on the mud surface. Associated with the final phase of rapid sulfate liberation in the aerobic tank, $\mathrm{pH}$ fell, and we may presume (as in the case of the writer's experiments mentioned earlier) that sulfuric

Table 23. Analyses of Inflow and Surface Waters from Malmam Tarn in Yorkshire, and Analyses from Pools on the Adjacent Raised Bog (ppm)

\begin{tabular}{|c|c|c|c|c|c|c|c|}
\hline & $\mathrm{Ca}$ & $\mathrm{Mg}$ & $\mathrm{Na}$ & $\mathrm{K}$ & $\mathrm{HCO}_{3}$ & $\mathrm{SO}_{4}$ & $\mathrm{Cl}$ \\
\hline Surface water & 47.3 & 2.4 & 3.4 & 0.6 & 143 & 14.1 & 4.1 \\
\hline Inflow water & 80.0 & 3.0 & 3.7 & 0.7 & 237 & 18.3 & 5.0 \\
\hline \multicolumn{8}{|l|}{ Bog pools in wet } \\
\hline weather & 0.5 & 0.2 & 1.6 & $<0.05$ & - * & 7.8 & 2.4 \\
\hline Ratio surface/inflow & 0.59 & 0.80 & 0.92 & 0.86 & 0.60 & 0.77 & 0.82 \\
\hline
\end{tabular}

* $\mathrm{pH} 3.9$

of peat, unpublished analyses are also included in Table 23 for pools from the surface of the Malham bog. These exhibit the characteristic acidity and calcium deficiency of such waters, completely blocked from drainage percolating mineral soils. In the present instance such soil drainage is alkaline and strongly calcareous.

Another indirect effect of organisms is manifested by the reduction of sulfate to sulfide where biological oxygen consumption has produced anaerobic environments, as for example in the interstitial waters of peats or lake muds, where sulfur may be dissolved as hydrogen sulfide or precipitated as ferrous sulfide. Fixation of sulfur in aquatic sediments is much greater in fertile than in unproductive lakes (Gorham, 1960). Sulfide can also be oxidized again by certain micro-organisms under suitable conditions. Moreover, some sulfate can apparently persist even in completely anaerobic lake muds (Koyama and Sugawara, 1951; Sugawara, Koyama, and Kozawa, 1953, p. 19).

The sulfur cycle has been treated recently by Hutchinson (1957, Chapter 13, p. 753), who gives many examples of the vertical distribution of sulfur compounds in lakes. The work of Mortimer (1941-1942) is particularly interesting in this connection, since in addition to acid was being formed by oxidation of sulfides. In analyzing waters from just above the mud in Esthwaite Water during 1940, Mortimer observed a similar situation following the onset of stratification. During the carly stages while oxygen remained abundant (although declining rapidly), sulfate increased somewhat in the bottom waters. As anaerobiosis set in, however, sulfate decreased from a maximum of about 9 ppm to 4 ppm in late summer. At the autumnal overturn, when bottom waters were mixed with aerated epilimnion waters much richer in sulfate, sulfate levels just above the mud rose sharply to about $10 \mathrm{ppm}$.

In shallow bodies of water, reduction to sulfide can probably lower sulfate levels in summer even at the surface (Mann, 1958). Marked decline of sulfate in surface waters of some shallow Uppland lakes during summer (Lohammar, 1938) may be due to such reduction. Possibly the low sulfate levels of some surface lake waters in Wisconsin, Norrland, and Dalarna-much below average levels in rain (see Table 5) - may also be caused by reduction to sulfide. In the very saline surface waters of the Sambhar Lake in India (Holland and Christie, 1909), and of Lake Corangamite in Australia (V. G. Anderson, 1945), sulfate levels 
are considerably below those expected in waters of oceanic derivation. The authors invoke sulfate reduction, remarking a distinct odor of hydrogen sulfide around the lakes, which at Sambhar becomes "an intolerable stench" when the lake is drying up.

In exceptional circumstances biological reduction may lower sulfate concentrations even in river waters, as shown by analyses of the White Nile above and below the swamps of the "Sudd." In these very extensive swamps, reduction may bring sulfate levels down to 1 ppm or less (Clarke, 1924, p. 109; Talling, 1957, p. 80).

Another indirect effect of organisms upon water chemistry comes from their provision of organic molecules for complexing, and hydrogen ions for weathering and ion exchange with soil colloids. This is important not only in lake muds but also in semiaquatic peats and in normal terrestrial soils.

The effect of a peat blanket upon the chemistry of waters was briefly mentioned in connection with Malham Tarn. In other parts of the British Isles depletion of calcium and bicarbonate, together with increasing acidity, follow upon peat accumulation and isolation of surface waters from the mineral soil (Gorham and Pearsall, 1956; Gorham, 1956a; 1956b, 1957e). Swedish data of Witting (1947; 1948), summarized by Gorham (1955a, Table 3, p. 143), show the same general trends, with pools on deep raised or blanket bog peats apparently deriving their entire mineral supply from atmospheric precipitation.

Human interference is a biotic factor of great importance for water chemistry. Eriksson (1958, p. 156) estimated that human activities might account for 15 per cent of the total chloride and 14 per cent of the total sulfur draining into the ocean, while Hanya (1951, p. 4) reckoned that about 31 per cent of Japanese river chloride is due to human use of salt.

Eriksson (1955, p. 245) believed that potassium fertilizers contribute small but appreciable amounts of chloride to Swedish river waters, and fertilization may be important for sulfate supply to lakes in agricultural districts, since it is commonly an accessory in fertilizers employed for other components (e.g., ammonium sulfate). Such involuntary sulfate fertilization can have profound effects on lake metabolism (Ohle, 1954; 1955a). Bicarbonate status and $\mathrm{pH}$ of lake waters can be greatly affected by the use of lime as a soil ameliorant. Addition of NPK fertilizers to lakes, and especially to farm ponds, is frequently carried out to improve fishing, but unfortunately little attention has been paid to its effect upon concentrations of major ions in the water. P. H. Barrett (1957) reports that potassium concentration in surface waters of a small trout lake returned to normal within 1 year of fertilization. Lime and basic slag are now employed in attempts to improve trout fishing in acid bog lakes, but again information upon subsequent long-term changes in $\mathrm{pH}$, alkalinity, and calcium status are generally lacking. When large amounts of basic slag were added to the acid and extremely calciumdeficient waters of two small Nova Scotian lakes, no apparent effect upon levels of calcium or $\mathrm{pH}$ could be detected 7 years later (Gorham 1957b, p. 16).

Air pollution is another means by which human beings alter the chemistry of natural waters. Gorham (1955b, 1958a; 1958d) has stressed its significance for the supply of various ions in rain, especially sulfate, and shown that the composition of waters in bog pools and upland tarns on volcanic rocks will thereby be greatly affected. Barrett and Brodin (1955) note the possible influence of dairies, cement works, cellulose industries, and oil-shale plants on the $\mathrm{pH}$ of precipitation in Sweden. On a world-wide scale Eriksson (1958, p. 156) estimated that fuel combustion may contribute about 5 per cent of the total sulfur carried by rivers. Junge and Werby (1958, p. 424) calculated that fuel combustion may account for one-third of the non-marine sulfur brought down each year by precipitation.

Irrigation exerts a strong influence on the composition of natural waters in arid districts. On this account Hutchinson (1957, p. 565) found it impossible to use recent analyses in elucidating the chemical evolution of lake waters in the Lahontan Basin of western America. Clarke (1924, p. 69) provided examples of the changes which may occur, citing Headden's data for the Cache de la Poudre River, which originates in the mountains of Colorado and flows out upon the plains. This is initially a dilute and predominantly bicarbonate water with a salinity of $37 \mathrm{ppm}$. Since it is utilized for irrigation in the arid lowlands, however, it acquires large quantities of easily soluble sulfates, which finally predominate strongly over bicarbonates in the extremely saline waters $(1571 \mathrm{ppm})$ reaching the town of Greeley. Headden's analyses of the Arkansas River in Colorado give a similar picture, but a different one emerges from analyses by Clarke 
(1924, p. 158) and others of water from Utah Lake, where irrigation is probably responsible for transforming rather fresh water dominated by sulfate (salinity $306 \mathrm{ppm}$ ) into a markedly saline chloride water (salinity about 1300 ppm).

The reverse process of land drainage may also affect water chemistry considerably, resulting chiefly in enrichment of sulfates through oxidation of ferrous sulfide, free sulfur, and organic sulfur in the soil. Ohle (1955a) has noted its significance in fertile North German lakes, where the additional sulfur from this source and from fertilizers has greatly increased the production of hydrogen sulfide in bottom waters during summer stagnation. When sulfuric acid is produced by sulfide oxidation following drainage, the entry of this strong mineral acid into stream and lake waters may neutralize bases and lower bicarbonate concentrations (Ohle, 1953).

In lands that have undergone a period of marine submergence, soil drainage may add chlorides to lake waters through capillary rise of relict marine salts into the upper layers of the soil. Such a situation was revealed through colonization of a Swedish lake shore by plants characteristic of saline soils (Lohammar, 1949). Similar effects may possibly cause relatively high chloride concentrations in the lakes of Uppland nearest sea level (Fig. 1).

Land clearance might also be expected to bring about changes in the chemistry of natural waters. According to Wood (1924) it has increased the rate of salinization of Western Australian reservoirs appreciably; accumulated salts are washed from the soils owing probably to greatly increased drainage through the deeper saline layers of the soil.

\section{Time}

The last major factor affecting the chemical composition of natural waters is time. This factor is difficult to examine directly over periods which amount to more than a minute fraction of the age of a lake or river. Most conclusions regarding lake evolution, therefore, rest on the assumption that lakes of similar age but differing characteristics may represent different stages of the same sequence. Such conclusions must be treated with caution.

The likely course of chemical evolution in saline lakes, as construed by Clarke (1924, p. 180) and Hutchinson (1957, p. 566), has already been considered. The general evolutionary tendencies of lakes in less arid regions, however, are considerably more difficult to interpret, since local differences in environment may have much greater influence where the climatic factor is not of such overriding importance. Where leaching of the soil has been intense, for example, and especially where acid peats have accumulated in the drainage basin, lake waters might be expected to become more dilute, acid, and deficient in calcium as the landscape ages; in situations where silting has been pronounced, an enrichment in calcium and other ions might be anticipated.

It seems possible that many lakes were enriched in salts just at the end of the Pleistocene, when pulverized rock deposited by glaciers was releasing large amounts of easily soluble mineral salts. Some of the varves beneath the organic muds of Esthwaite Water in the English Lake District, for example, contain free calcium carbonate, which is absent from the muds themselves (Mackereth, oral communication, 1958). It may therefore be inferred that levels of calcium and bicarbonate in the lake water were higher at the beginning of postglacial time than at any time afterward, even in this silted and rather fertile basin. To investigate release of salts from pulverized rock in the Lake District, Gorham (1958a, p. 165) analyzed a stream water leaching dumps of powdered slate from a quarry and found it contained $2.9 \mathrm{~m}$ equiv. 1 of total salts, and exhibited a pH of 8 ; most lakes draining similar but weathered substrata had waters with much less than $1 \mathrm{~m}$ equiv. 1 of total salts and circumneutral reaction.

Botanical evidence may sometimes help in reconstructing broad outlines of chemical evolution in lakes. For instance, the composition of the extremely rich diatom floras in the lakes of the English Lake District at or just after the close of the last glaciation reinforces the suggestion that these waters were much richer in calcium than the present lake waters are (Lund, 1959). Indeed Lund suggests that Lake District soils must have been rather calcareous at that time, and probably carried a land flora very different from the present one. ( $C f$. Gorham 1953, p. 148.) Round (1957) found that the diatom stratigraphy of Kentmere in the English Lake District suggests a transition from alkaline to faintly acid waters in the moist early Atlantic period, when peat accumulation in northern England was greatly accelerated. This is in contrast to the hypothesis, also discussed briefly by Round, that evolution of a glacial lake basin commonly involves increasing fertility. 
Age, however, was not the only factor involved in the evolution of Kentmere; a climatic shift also strongly influenced lake development. In the history of lake basins it is the rule rather than the exception that changes in other environmental factors complicate the effects of age alone. Thus the time factor, like the biotic factor, can seldom be treated as a wholly independent variable. The effects of Triassic rocks and climate, and of later marine submergence, upon the water chemistry of the Cheshire meres (Gorham, 1957c) provide a good example of the influence of the past upon present conditions, as do also the striking variations in the lake waters of Uppland and Dalarna in Sweden. Effects of air pollution upon natural waters have also increased greatly in the last century or so.

In addition to long-term evolutionary trends, short-term fluctuations are also to be considered, some of a regular recurring nature and others more or less irregular. To various seasonal changes in the chemistry of both rain and lake waters should be added fluctuations over longer periods, as for example those due to less regular climatic cycles of greater duration than 1 year.

The work of Rossby and Egnér (1955) illustrates the effect of such climatic changes on the chemistry of precipitation. These authors observed that between 1949 and 1953 the decreasing ventilation of south Sweden by maritime air masses resulted in lessened deposits of sodium and chloride there, while the increased influence of winds from central Europe led to greater deposition of sulfate.

The effect of time, through climatic change, upon the chemistry of surface waters of some Saskatchewan lakes has been examined by Rawson (1951, p. 671). Here a chain of three lakes in the Prince Albert National ParkKingsmere, Waskesiu, and Montreal-showed in 1950 a distinct increase of total solids in the downstream direction, with successive values of 169,188 , and $195 \mathrm{ppm}$ in their waters. The lowest of the three, Lake Montreal, drains into Lac la Ronge, which, however, had a lower content of total solids, $179 \mathrm{ppm}$, owing to reception of considerable drainage from Precambrian rocks. The 1950 data followed several years of normal runoff, but in the drought period of 1930-1936 Lake Waskesiu had little or no outflow, and its total solid concentration rose to $200 \mathrm{ppm}$. In contrast, Lac la Ronge in 1941 had only 137 ppm, presumably because during the previous 10 years there had been little inflow from the Prince Albert lakes, and most of the drainage had come from Precambrian strata. Thus in the cases of Waskesiu and Lac la Ronge the drought period produced opposite results.

The effect of time, through both seasonal and long-term climatic change, upon the salt content of extremely saline lake waters has also been discussed by Rawson. According to Rawson and Moore (1944) saline lakes in Saskatchewan became much more concentrated during the drought of the 1930's. Data for Great Salt Lake in Utah show two major cycles of increase and decrease over the past century, with the maximum observed salinity about twice the minimum.

Irregular fluctuations in the chemistry of natural waters may also appear within very short periods, owing to the diluting and concentrating effects of wet and dry weather. The chloride concentration of the Saline River, in an arid part of Kansas, varies inversely with stream discharge; the correlation coefficient $(r)$ for a large number of observations is 0.94 (Durum, 1953). The relationship is approximately hyperbolic, with $C l \times Q=K$, where $C l$ is the chloride concentration in parts per million, $Q$ is the discharge in cubic feet per second, and $K$ is a constant with a value in this case of 34,500 . Chloride discharge is thus about 93 tons per day. Macan (1950) shows the possible extent of such fluctuations in a humid climate, by a series of conductivity and alkalinity analyses from tarns and pools in the English Lake District, while Douglas (1958) provides more extended data for a single small Lake District stream.

Extreme dry- and wet-weather analyses of bog pools and an upland stream given by Gorham (1956b) show striking differences not only in concentration but also in ionic proportions. The size of a body of water is of great importance in this connection, for although large lakes may take years for complete water replacement, the process may take only a few wceks in small lakes (Gorham 1958c, p. 46), and small pools may be flushed out considerably by a single heavy rain. Marked differences in both concentration and ionic proportions observed during repeated sampling of upland tarns in the English Lake District may well be due to such rapid flushing, with rain from different quarters supplying water of differing quality (Mackereth, 1957). 
INTERACTIONS AND

\section{CONCLUSION}

The work of Colby, Hembree, and Rainwater (1956, p. 117) on the streams of the Wind River Basin in Wyoming clearly illustrates the chemical variation of natural waters in response to interactions of partially independent environmental factors. There streams on Precambrian and Paleozoic rocks generally carry dilute waters dominated by calcium and bicarbonate, as do streams on Tertiary volcanic rocks. In contrast, some streams draining Mesozoic strata contain considerable calcium, sulfate, sodium, and bicarbonate. The Bighorn River, which receives all these streams, exhibits marked fluctuations both in ionic concentration and in the composition of its waters, depending on the season and on the amount of precipitation. During minimum flow in winter, concentrations are a good deal higher than during the floods of early summer. However, maximum ion concentrations are observed not during the winter period of minimum flow, when snowmelt provides very dilute runoff, but during precipitation on or ground water discharge from the Mesozoic strata, when the ratios of sodium to calcium and sulfate to bicarbonate increase. The influence of topography is at work here too, insofar as runoff is more rapid in the mountainous Precambrian areas of the basin, and little time is allowed there for solution of salts by rain and snowmelt.

Environmental factors may sometimes exert parallel effects; for instance, low rainfall may act in the same direction as high temperature or easily weathered rocks rich in soluble constituents to produce relatively high ionic concentrations in natural waters. On the other hand, compensating effects may be apparent in certain circumstances. Thus low rainfall, by lessening the degree of leaching, may counterbalance the tendency toward dilute waters where there is a low content of readily soluble ions in the soil. Under a climate humid enough to bring about extensive leaching and peat formation even on lime-rich substrata, acid waters deficient in calcium may be found where under a drier climate distinctly alkaline and calcareous waters might be expected. Such results are exemplified by the acid waters found in parts of the English Pennines, where Carboniferous limestone is overlain in many places by extensive peat deposits (Gorham, 1956b).

The same envirommental change may also produce opposite effects in different situations. In the English Pennines wet weather may raise the $\mathrm{pH}$ of waters in bog pools, by washing sulfuric acid produced during dry weather out of them and into near-by alkaline streams, whose $\mathrm{pH}$ is lowered partly owing to neutralization of their bicarbonate and partly to dilution by rainfall which is also rather acid (Gorham, 1956b, p. 376). Berg (In press) finds that the acidity of streams in the central basin of the Belgian Congo rises during floods for a similar reason.

In any consideration of environmental influence upon water chemistry, it must be remembered that the factors are not wholly independent. For instance, the high salt concentrations of the Cheshire mere waters depend on the richness of the Triassic substrata in salts, determined in turn by Triassic climate and topography, and therefore also by the time factor. Similarly, the increase in chloride concentration of lake waters with decreasing altitude is commonly due to topographic influence upon the climatic factors precipitation and evaporation.

By recognizing that differences in ionic composition so frequently encountered in natural inland waters are commonly due to a complex of interacting environmental variables, we may be impelled to search for situations where differences in water chemistry are clearly due to variation in a single environmental factor. Such a single-factor approach has been most fruitful for soil science (Jenny, 1941) and promises also to be of great value in plant ecology (Major, 1951). Its application to the chemistry of natural waters would seem a logical approach to a subject hitherto investigated not so much for its own sake as for the light it might throw upon related problems.

\section{REFERENCES CITED}

Alekin, O. A., and Brazhnikova, L. V., 1957, New data on the average composition of river water for the territory of the USSR: Acad. Sci. USSR Proc., v. 114, p. 49-52

Anderson, D. H., and Hawkes, H. E., 1958, Relative mobility of the common elements in weathering of some schist and granite areas: Geochim. Cosmochim. Acta, v. 14, p. 204-210 
Anderson, G. C., 1958, Some limnological features of a shallow saline meromictic lake: Limnology and Occanography, v. 3, p. 259-270

Anderson, V. G., 1945, Some effects of atmospheric evaporation and transpiration on the composition of natural waters in Australia: Austral. Chem. Inst. Jour. and Proc., v. 12, p. 41-68, 83-98

Anonymous, 1958, Air pollution measurements of the national air sampling network: U.S. Pub. Health Service Publ. 637, 259 p.

Arrhenius, O., 1952, The chemical denudation of the soil: Tellus, v. 4, p. 307-310

Ayers, J. C., Anderson, D. V., Chandler, D. C., and Lauff, G. H., 1956, Currents and water masses of Lake Huron: Great Lakes Research Inst. Tech. Paper no. 1, 101 p.

Barrett, E., and Brodin, G., 1955, The acidity of Scandinavian precipitation: Tellus, v. 7, p. 251-257

Barrett, P. H., 1957, Potassium concentrations in fertilized trout lakes: Limnology and Oceanography, v. 2, p. 287-294

Bear, F. E., 1954, Trace elements, progress report on research with particular reference to New Jerscy soils: Agric. and Food Chemistry, v. 2, p. 244-251

Beauchamp, R. S. A., 1939, Hydrology of Lake Tanganyika: Internat. Rev. Hydrobiology and Hydrography, v. 39 , p. $316^{-353}$

1953, Sulphates in African inland waters: Nature, v. 171, p. 769

Berg, A., In press, Rôle écologique des eaux de la cuvette congolaise sur la croissance de la jacinthe d'eau: Acad. Roy. Sci. d'Outre-Mer Mém.

Billings, W. D., 1952, The environmental complex in relation to plant growth and distribution: Quart. Rev. Biology, v. 27, p. 25I-265

Böcher, T. W., 1949, Climate, soil, and lakes in continental west Greenland in relation to plant life: Medd. om Gronland, v. 147, no. 2, 63 p.

Bottini, O., 1939, Le pioggie caustiche nella regione vesuviana: Ann. Chim. Applic, v. 29, p. 425-433

Bowen, E. G., 1956, The relation between rainfall and meteor showers: Jour. Meteorology, v. 13, p. $142-151$

Boyce, S. G., 1951, Source of atmospheric salts: Science, v. 113, p. 620-621

- 1954, The salt spray community: Ecol. Mon., v. 24, p. 29-67

Boyd, W. L., 1959, Limnology of selected arctic lakes in relation to water supply problems: Ecology, v. 40, p. $49-54$

Broecker, W. S., and Walton, A. F., 1959, Re-evaluation of the salt chronology of several Great Basin lakes: Geol. Soc. America Bull., v. 70, p. 601-618

Carritt, D. E., and Goodgal, S., 1954, Sorption reactions and some ecological implications: Deep Sea Research, v. 1, p. 224-243

Carroll, D., 1958, Role of clay minerals in the transportation of iron: Geochim. Cosmochim. Acta, v. 14, p. $1-27$

Cauer, H., 1949, Ergebnisse chemisch-meteorologischer Forschung: Arch. Meteorol. Geophys. Bioklim., B, v. 1, p. 221-256

- 1951, Some problems of atmospheric chemistry: Compendium of Meteorology, p. 1126-1136

Chenery, E. M., 1953, A digest of the chemistry of dead swamps in Kigezi District, S. W. Uganda: Hydrol. Survey Dept., Entebbe, Uganda, Ann. Rept., 1952, 6 p.

Chilingar, G. V., 1956, Durov's classification of natural waters and chemical composition of atmospheric precipitation in USSR: a review: Am. Geophys. Union Trans., v. 37, p. 193-196

Clarke, F. W., 1924, The data of geochemistry, 5th ed: U. S. Gcol. Survey Bull. 770, 841 p.

Colby, B. R., Hembree, C. H., and Rainwater, F. H., 1956, Sedimentation and chemical quality of surface waters in the Wind River Basin, Wyoming: U. S. Geol. Survey Water-Supply Paper 1373, 336 p.

Conway, E. J., 1942, Mean geochemical data in relation to oceanic evolution: Royal Irish Acad. Proc., B, v. 48 , p. $119-159$

Crocker, R. L., 1952, Soil genesis and the pedogenic factors: Quart. Rev. Biology, v. 27, p. 139-168

Cunningham, R. M., 1941, Chloride content of fog water in relation to air trajectory: Am. Meteorol. Soc. Bull., v. 22, p. $17-20$

Denisov, P. V., and Bugaiov, A. L., 1956, The chemical composition of atmospheric precipitations of the northeastern part of the Ukraine (English translation): Acad. Sci. USSR Proc., Scct. Geochemistry, $v .108$, p. $37-39$

Department of Scientific and Industrial Research, Great Britain, 1955, Report on the investigation of atmospheric pollution, no. $27,207 \mathrm{p}$. 
Douglas, B., 1958, The ecology of the small attached diatoms and other algae in a small stony stream: Jour. Ecology, v. 46, p. 295-322

Durum, W. H., 1953, Relationship of the mineral constituents in solution to stream flow, Saline River near Russell, Kansas: Am. Geophys. Union Trans., v. 34, p. 435-442

Emanuelsson, A., Eriksson, E., and Egnér, H., 1954, Composition of atmospheric precipitation in Sweden: Tellus, v. 6, p. 261-267

Eriksson, E., 1952, Composition of atmospheric precipitation II. Sulfur, chloride, iodine compounds. Bibliography: Tellus, v. 4, p. 280-303

- 1955, Air borne salts and the chemical composition of river waters: Tellus, v. 7, p. 243-250

- 1958, The chemical climate and saline soils in the arid zone: Arid Zone Research X. Climatologv, Reviews of Research, Canberra Symposium Proc., p. 147-180 (UNESCO)

- 1960, The yearly circulation of chloride and sulfur in nature; metcorological, geochemical and pedological implications, part II: Tellus, v. 12, p. 63-109

Foster, M. D., 1950, The origin of high sodium bicarbonate waters in the Atlantic and Gulf coastal plains: Geochim. Cosmochim. Acta, v. 1, p. 33-48

Frederick, L. R., Starkey, R. L., and Segal, W., 1957, Decomposability of some organic sulfur com. pounds in soil: Soil Sci. Soc. Am. Proc., v. 21, p. 287-292

Gorham, E., 1953, The development of the humus layer in some woodlands of the English Lake District: Jour. Ecology, v. 41, p. 123-152

1955a, On some factors affecting the chemical composition of Swedish fresh waters: Geochim. Cosmochim. Acta, v. 7, p. 129-150

1955b, On the acidity and salinity of rain: Geochim. Cosmochim. Acta, v. 7, p. 231-239

-1956a, The ionic composition of some bog and fen waters in the English Lake District: Jour. Ecology, v. 44 , p. $142-152$

- 1956b, On the chemical composition of some waters from the Moor House nature reserve: Jour. Ecology, v. 44, p. 377-384

1957a, The chemical composition of rain from Rosscahill in County Galway: Irish Nat. Jour., v. 12, p. $122-126$

- 1957b, The chemical composition of lake waters in Halifax County, Nova Scotia: Limnology and Oceanography, v. 2, p. 12-21

- $1957 \mathrm{c}$, The ionic composition of some lowland lake waters from Cheshire, England: Limnology and Oceanography, v. 2, p. 22-27

- $1957 \mathrm{~d}$, The chemical composition of some waters from lowland lakes in Shropshire, England: Tellus, v. 9 , p. 174-179

- 1957e, The chemical composition of some western Irish fresh waters: Royal Irish Acad. Proc., B, v. 58 , p. $237-243$

- 1957f, The chemical composition of some natural waters in the Cairn Gorm-Strath Spey district of Scotland: Limnology and Oceanography, v. 2, p. 143-154

- 1958a, The influence and importance of daily weather conditions in the supply of chloride, sulphate and other ions to fresh waters from atmosplicric precipitation: Royal Soc. London Philos. Trans., B, v. 247, p. $147-178$

1958b, Free acid in British soils: Nature, v. 181, p. 106

- 1958c, The physical limnology of northern Britain: an epitome of the bathymetrical survey of the Scottish freshwater lochs, 1897-1909: Limnology and Oceanography, v. 3, p. 40-50

- 1958d, Atmospheric pollution by hydrochloric acid: Royal Meteorol. Soc. Quart. Jour., v. 84, p. $274-276$

- 1958e, Observations on the formation and breakdown of the oxidized microzone at the mud surface in lakes: Limnology and Oceanography, v. 3, p. 291-298

- 1958f, Free acid in Minnesota podzols: Ecology, v. 39, p. 770

1958g, Soluble salts in dune sands from Blakency Point in Norfolk: Jour. Ecology, v. 46, p. 373-379

1958h, Soluble salts in a temperate glacier: Tellus, v. 10, p. 496-497

1960, The relation between sulfur and carbon in sediments from the English Lakes: Jour. Sedim. Petrology, v. 30 , p. $466-470$

- 1961, The chemical composition of some waters from dune slacks at Sandscale, North Lancashire: Jour. Ecology, v. 49, p. $79-82$ 
Gorham, E., and Cragg, J. B., 1960, The chemical composition of some bog waters from the Falkland Islands: Jour. Ecology, v. 48, p. 175-181

Gorham, E., and Gordon, A. G., 1960, The influence of smelter fumes upon the chemical composition of lake waters near Sudbury, Ontario, and upon the surrounding vegetation: Canad. Jour. Botany, v. 38, p. $477-487$

Gorham, E., and Pearsall, W. H., 1956, Acidity, specific conductivity and calcium content of some bog and fen waters in northern Britain: Jour. Ecology, v. 44, p. 129-14l

Guppy, E. M., 1931, Chemical analyses of igneous rocks, metamorphic rocks and minerals: London, H.M. Stationery Office, $166 \mathrm{p}$.

- 1956, Chemical analyses of igneous rocks, metamorphic rocks and minerals, 1931-1954: London, H. M. Stationery Office, $78 \mathrm{p}$.

Hanya, T., 1951, Average composition of Japanese fresh waters and some considerations on it: Internat. Assoc. Hydrology, Brussels Assembly, August 1951, 5 p.

Harrison, J. B., 1934, The katamorphism of igneous rocks under humid tropical conditions: Harpenden, England, Imp. Bur. Soil Sci., 79 p.

Hayes, F. R., and Anthony, E. H., 1958, Lake water and sediment. I. Characteristics and water chemistry of some Canadian east coast lakes: Limnology and Oceanography, v. 3, p. 299-307

Hem, J. D., 1959, Study and interpretation of the chemical characteristics of natural water: U. S. Geol. Survey Water-Supply Paper 1473, 269 p.

Herman, F. A., and Gorham, E., 1957, Total mineral material, acidity, sulphur and nitrogen in rain and snow at Kentville, Nova Scotia: Tellus, v. 9, p. 180-183

Hesse, P. R., 1958, Fixation of sulphur in the muds of Lake Victoria: Hydrobiologia, v. 11, p. 171-181

Holdgate, M., 1955, The vegetation of some British upland fens: Jour. Ecology, v. 43, p. 389-403

Holland, T. H., and Christie, W. A. K., 1909, The origin of the salt deposits of Rajputana: Geol. Survey India Records, v. 38, p. 154-186

Hooper, F. F., 1956, Some chemical and morphometric characteristics of southern Michigan lakes: Michigan Acad. Sci., Arts and Letters Papers, v. 41, p. 109-130

Houghton, H. G., 1955, On the chemical composition of fog and cloud water: Jour. Meteorology, v. 12, p. $355-357$

Hutchinson, G. E., 1957, A treatise on limnology I. Geography, physics, chemistry: New York, John Wiley \& Sons, 1015 p.

Hutchinson, G. E., Wollack, A., and Setlow, J. K., 1943, The chemistry of lake sediments from Indian Tibet: Am. Jour. Sci., v. 241 , p. 533-542

Hutton, J. T., 1958, The chemistry of rainwater with particular reference to conditions in southeastern Australia: Arid Zone Research XI, Climatology and Microclimatology, Canberra Symposium Proc., p. 285-292 (UNESCO)

Hutton, J. T., and Leslie, T. I., 1958, Accession of non-nitrogenous ions dissolved in rainwater to soils in Victoria: Austral. Jour. Agric. Research, v. 9, p. 492-507

Ingham, G., 1950, Effect of materials absorbed from the atmosphere in maintaining soil fertility: Soil Sci., v. 70, p. 205-212

Jenny, H., 1941, Factors of soil formation: New York, McGraw-Hill, $281 \mathrm{p}$.

1950, Origin of soils, p. 41-61 in Trask, P. D., Applied sedimentation: New York, John Wiley \& Sons, $707 \mathrm{p}$.

Joffe, J. S., 1933, Lysimeter studies II. The movement and translocation of soil constituents in the soil profile: Soil Sci., v. 35 , p. $239-257$

- 1940, Lysimeter studies IV. Movement of anions through the profile of a gray-brown podzolic soil: Soil Sci., v. 50, p. 57-63

Juday, C., and Birge, E. A., 1933, The transparency, the color and the specific conductance of the lake waters of northeastern Wisconsin: Wis. Acad. Sci., Arts and Letters Trans., v. 28, p. 205-259

Junge, C. E., 1954, The chemical composition of atmospheric aerosols I. Measurements at Round Hill field station, June-July 1953: Jour. Meteorology, v. 11, p. 323-333

- 1956, Recent investigations in air chemistry: Tellus, v. 8, p. 127-139

- 1957, Facts and problems of chemical composition of condensation nuclei in unpolluted and polluted atmospheres, p. 31-35 in Weickman, H., and Smith, W. E., The artificial stimulation of rain: London, Pergamon Press, 427 p.

1958, Atmospheric chemistry: Adv. Geophysics, v. 4, p. 1-108 
Junge, C. E., and Gustafson, P. E., 1957, On the distribution of sea salt over the United States and its removal by precipitation: Tellus, v. 9, p. 164-173

Junge, C. E., and Ryan, T. G., 1958, Study of the $\mathrm{SO}_{2}$ oxidation in solution and its rolc in atmospheric chemistry: Royal Meteorol. Soc. Quart. Jour., v. 84, p. 46-55

Junge, C. E., and Werby, R. T., 1958, The concentration of chloride, sodium, potassium, calcium and sulfate in rain water over the United States: Jour. Metcorology, v. 15, p. 417-425

Kalle, K., 1953-1954, Zur Frage des "cyklischen Salzes": Ann. Meteorol., v. 6, p. 305-314

Katz, M., Editor, 1939, Effect of sulphur dioxide on vegetation: Ottawa, Nat. Research Council Publ. $815,447 \mathrm{p}$.

Keller, W. D., 1957, The principles of chemical weathering: rev. ed., Columbia, Mo., Lucas Bros., 111 p.

Keller, W. D., and Frederickson, A. F., 1952, Role of plants and colloidal acids in the mechanism of weathering: Am. Jour. Sci., v. 250, p. 594-608

Kivinen, E., 1955, On acid saline soils or sulphate soils: Nat. Acad. Sci. (India) Allahabad Proc., A, v. 24, p. $621-624$

Kobayashi, J., 1955, Chemical investigation on the water of rivers in Japan III. The nature of water in the Kanto districts: Ohara Inst. Landwirtsch. Biol. Berichte, v. 10, p. 157-214

Köhler, H., 1923, Zur Kondensation des Wasserdampfes in der Atmosphäre: Geofys. Publ. (Kristiania, Norway), v. 2, no. 6, 15 p.

- 1937, Studien über Nebelfrost und Schneebildung und über Chlorgehalt des Nebelfrostes, des Schnees und des Seewassers in Halldegebiet: Geol. Inst. Univ. Upsala Bull., v. 26, p. 279-308

Koyama, T., 1953, Measurement and analysis of gases in sediments: Jour. Earth Sci. Nagoya, v. 1, p. $107-118$

Koyama, T., and Sugawara, K., 1951, Sulphate co-precipitation in lake and sea and its concentration in the bottom deposits: Oceanogr. Soc. Japan Jour., v. 6, p. 190-193

- 1953, Separation of the components of atmospheric salt and their distribution (cont'd): Chem. Soc. Japan Bull., v. 26, p. 123-126

Langbein, W. B., In press, The salinity and hydrology of closed lakes: U. S. Geol. Survey Water-Supply Paper

Leeflang, K. W. A., 1938, De chemische Samenstellung van den Neerslag in Nederland: Chem. Wcekbl., v. 35 , p. $658-664$

Lewis, C. C., and Eisenmenger, W. S., 1948, Relationship of plant development to the capacity to utilize potassium in orthoclase feldspar: Soil Sci., v. 65, p. 495-500

Lodge, J. P., Jr., Macdonald, A. J., Jr., and Vihman, E., 1960, A study of the composition of marine atmospheres: Tellus, v. 12, p. $184-187$

Lohammar, G., 1938, Wasserchemie und höhere Vegetation schwedischer Scen: Symbolac Botanicae Upsalienses, v. 3, no. 1, 252 p.

- 1949, En halofytförekomst i Västerbottens inland och dess betydelse för tolkningen ay de s.k. havstrandsrelikterna i Uppland: Svensk Bot. Tidskr., v. 43, p. 448-459

Lund, J. W. G., 1957, Chemical analysis in ecology illustrated from Lake District tarns and lakes 2. Algal differences: Linnaean Soc. London Proc., v. 167, p. 165-171

- - 1959, Investigations on the algac of Lake Windermere: Adv. Sci., v. 15, p. 530-534

Lundqvist, G., 1935, Isavsmältningen inom Bergslagen: Geol. Fören. Stockholm Förhandl., v. 52, p. $287-301$

Lutz, H. J, and Chandler, R. F. Jr., 1946, Forest soils: New York, John Wiley \& Sons, 514 p.

Macan, T. T., 1950, Ecology of fresh-water mollusca in the English Lake District: Jour. Animal Ecology, v. 19, p. $124-146$

MacIntire, W. H., and Young, J. B., 1923, Sulfur, calcium, magnesium and potassium content and reaction of rainfall at different points in Tennessec: Soil Sci., v. 15, p. 205-227

Mackereth, F. J. H., 1957, Chemical analysis in ecology illustrated from Lake District tarns and lakes 1. Chemical analysis: Linnaean Soc. London Proc., v. 167, p. 159-164

Mackereth, F. J. H., and Heron, J., 1954, p. 20-21 in Freshwater Biol. Assoc. British Empire Ann. Rept. no. 22,63 p.

Madgwick, H. A. I., and Ovington, J. D., 1959, The chemical composition of precipitation in adjacent forest and open plots: Forestry, v. 32, p. 14-22

Major, J., 1951, A functional, factorial approach to plant ecology: Ecology, v, 32, p. 392-412 
Malmer, N., and Sjörs, H., 1955, Some determinations of elementary constituents in mire plants and peat: Bot. Notiser Lund, p. 46-80

Mann, K. H., 1958, Annual fluctuation in sulphate and bicarbonate hardness in ponds: Limnology and Oceanography, v. 3, p. 418-422

Mason, B., 1952, Principles of geochemistry: New York, John Wiley and Sons, 276 p.

Meetham, A. R., 1950, Natural removal of pollution from the atmosphere: Royal Meteorol. Soc. Quart. Jour., v. 76, p. $359-371$

- 1954, Natural removal of atmospheric pollution during fog: Royal Meteorol. Soc. Quart. Jour., v. 80 , p. $96-99$

Metzger, W. H., 1928, The effect of growing plants on solubility of soil nutrients: Soil Sci., v. 25, p. 273-280

Möller, L., 1949, Die chemische Beschaffenheit der Grund- und Oberflächen-gewässer Nordwestdeutschlands in Beziehung zu den geologischen Verhältnissen: Int. Ver. Limnol. Verh., v. 10, p. 317-334

- 1955, Geographische Verteilung der Konzentration gelöster Substanzen von Grund- und Oberfächengewässern Sudwestdeutschlands in limnologisches Sicht: Int. Ver. Limnol. Verh., v. 12, p. $351-359$

Mortimer, C. H., 1941-1942, The exchange of dissolved substances between mud and water in lakes: Jour. Ecology, v. 29 , p. $280-329$; v. 30, p. 147-201

- 1949, Seasonal changes in chemical conditions near the mud surface in two lakes of the English Lake District: Int. Ver. Limnol. Verh., v. 10, p. 353-356

Mortimer, C. H., and Mackereth, F. J. H., 1958, Convection and its consequences in ice-covered lakes: Int. Ver. Limnol. Verh., v. 13, p. 923-932

Neumann, G. H., Fonselius, S., and Wahlman, L., 1959, Measurements on the content of non-volatile organic material in atmospheric precipitation: Internat. Jour. Air Pollution, v. 2, p. 132-141

Oddie, B. C. V., 1959, The composition of precipitation at Lerwick, Shetland: Royal Meteorol. Soc. Quart. Jour., v. 85 , p. 163-165

Ohle, W., 1934, Chemische und physikalische Untersuchungen norddeutscher Seen: Arch. Hydrobiologie, v. 26, p. 386-464, 584-658

1953, Der Vorgang rasanter Seenalterung in Holstein: Naturwiss., v. 40, p. 153-162

- 1954, Sulfat als "Katalysator" des limnischen Stoffkreislaufes: Vom Wasser, v. 21, p. 13--32

1955a, Die Ursachen der rasanten Seeneutrophierung: Int. Ver. Limnol. Verh., v. 12, p. 373-382

1955b, Ionenaustausch der Gewässersedimente: Ist. Ital. Idrobiol. Mem., Suppl. 8, p. 221-245

Ovington, J. D., 1956, The composition of tree leaves: Forestry, v. 29, p. 22-28

1959, Mineral content of plantations of Pinus syluestris L.: Ann. Bot., n. s., v. 23, p. 75-88

Ovington, J. D., and Madgwick, H. A. I., 1959, The growth and composition of natural stands of birch 2. The uptake of mineral nutrients: Plant and Soil, v. 10, p. 389-400

Owens, J. S., 1940, Sea salt and condensation nuclei: Royal Meteorol. Soc. Quart. Jour., v. 66, p. 2

Pearsall, W. H., 1921, The development of vegetation in the English lakes, considered in relation to the general evolution of glacial lakes and rock basins: Royal Soc. London Proc., B, v. 92, p. 259-284

- 1929, Dynamic factors affecting aquatic vegetation: Internat. Cong. Plant Sci. Proc., v. 1, p. 667-672

Pennak, R. W., 1958, Regional lake typology in northern Colorado, U.S.A.: Int. Ver. Limnol. Verh., v. 13, p. 264-283

Piper, A. M., Garrett, A. A., and others, 1953, Native and contaminated ground water in the Long Beach-Santa Ana area, California: U. S. Geol. Survey Water-Supply Paper 1136, 320 p.

Polynov, B. B., 1937, The cycle of weathering: London, Thomas Murby, 220 p.

- 1951, Modern ideas of soil formation and development: Soils and Fertilizers, v. 14, p. 1-7 (transl. from Pochvovedenic, 1948, p. 3-13)

Powers, M.C., 1957, Adjustment of land derived clays to the marine environment: Jour. Sedim. Petrology, v. 27, p. $355-372$

Puke, C., 1949, Environment and productivity of lakes near Stockholm: Inst. Freshwater Research Drottningholm Rept., no. 29, p. 81-84

Rankama, K., and Sahama, T. G., 1950, Geochemistry: Chicago, Univ. Chicago Press, 912 p.

Rawson, D. S., 1950, The physical limnology of Great Slave Lake: Fish. Research Bd. Canada Jour., v. 8, p. $1-66$

1951, The total mineral content of lake waters: Ecology, v. 32, p. 669-672 
Rawson, D. S., and Moore, J. E., 1944, The saline lakes of Saskatchewan: Canad. Jour. Rescarch, D, v. 22, p. 141-201

Reiche, P., 1942, Polynov's cycle of weathering: Jour. Geomorphology, v. 5, p. 204-214

Renick, B., 1924, Base-exchange in ground water by silicates as illustrated in Montana: U. S. Geol. Survey Water-Supply Paper 520-D, p. 53-72

Richards, P. W., 1941, Lowland tropical podsols and their vegetation: Nature, v. 148, p. 129-131

Riffenburg, H. B., 1925, Chemical character of ground waters of the northern Great Plains: U. S. Geol. Survey Water-Supply Paper 560-B, p. 31-52

Robbins, R. C., Cadle, R. D., and Eckhardt, D. L., 1959, The conversion of sodium chloride to hydrogen chloride in the atmosphere: Jour. Meteorology, v. 16, p. 53-56

Robinson, G. W., 1949, Soils, their origin, constitution and classification, 3d ed: London, Thomas Murby, $573 \mathrm{p}$.

Rodhe, W., 1949, The ionic composition of lake waters: Int. Ver. Limnol. Verh., v. 10, p. 377-386

Romell, L. G., 1922, Luft växlingen i marken som ekologisk faktor: Statens Skogsförsöksanst. Stockholm Medd., v. 19, p. 125-359

Rossby, C. G., and Egnér, H., 1955, On the chemical climate and its variation with the atmospheric circulation pattern: Tellus, v. 7, p. 118-133

Round, F. E., 1957, The late-glacial and post-glacial diatom succession in the Kentmere valley deposit: New Phytol., v. 56, p. 98-126

Rubey, W. W., 1951, The geological history of sea water: an attempt to state the problem: Geol. Soc. America Bull., v. 62, p. $1111-1148$

Russell, E. W., 1950, Soil conditions and plant growth, 8th ed.: London, Longmans Green, 635 p.

Ruttner, F., 1953, Fundamentals of limnology, translated by D. G. Frey and F. E. J. Fry, Toronto, Univ. Press, 242 p.

Schatz, A., Cheronis, N. D., Schatz, V., and Trelawney, G. S., 1954, Chelation (sequestration) as a biological weathering factor in pedogenesis: Pa. Acad. Sci. Proc., v. 28, p. 44-51

Shapiro, J., 1957, Chemical and biological studies on the yellow organic acids of lake watcr: Limnology and Oceanography, v. 2, p. 161-179

Simpson, G. C., 1941a, On the formation of cloud and rain: Royal Mctcorol. Soc. Quart. Jour., ․ 67, p. 99-133

—-1941b, Sea salt and condensation nuclei: Royal Meteorol. Soc. Quart. Jour., v. 67, p. 163-169

Sioli, H., 1956, As aguas da regiao do alto Rio Negro: Inst. Agron. Norte Tecn. Bol., no. 32, p. 117-155

Smyth, C. H., 1913, The relative solubilities of the chemical constituents of rocks: Jour. Geology, v. 21, p. $105-120$

Squires, P., and Twomey, S., 1957, Some observations of sea-salt nuclei in Hawail during Project Shower: Tellus, v. 9 , p. $538-540$

Stenlid, G., 1958, Salt losses and redistribution of salts in higher plants, p. 615-637 in Ruhland, W., Encyclopedia of plant physiology, v. 4, Berlin, Springer Verlag, 1210 p.

Stocks, P., 1958, Cancer incidence in North Wales and Liverpool region in relation to habits and environment: British Empire Cancer Campaign 35th Ann. Rept., Suppl. to Pt. II, 156 p.

Strøm, K. M., 1939, Conductivity and reaction in Norwegian lake waters: Internat. Rev. Hydrobiology and Hydrography, v. 38, p. 250-261

Sturdy, D., Calton, W. E., and Milne, G., 1933, A chemical survey of the waters of Mount Meru, Tanganyika Territory: East Africa \& Uganda Nat. Hist. Soc. Jour., v. 11, p. 1-38

Sugawara, K., 1951, National report on hydrology_Japan: Internat. Assoc. Hydrology, Brussels Assembly, August 1951, $21 \mathrm{p}$.

Sugawara, K., Koyama, T., and Kozawa, A., 1953, Distribution of various forms of sulphur in lake-, river- and sea-muds: Jour. Earth Sci. Nagoya, v. 1, p. 17-23

Sugawara, K., Oana, S., and Koyama, T., 1949, Separation of components of atmospheric salt and their distribution: Chem. Soc. Japan Bull., v. 22, p. 47-52

Swenson, H. A., 1953, Geochemical relationships of water in the Powder River Basin. Wyoming and Montana: Am. Geophys. Union Trans., v. 34, p. 443-448

Talling, J.F., 1957. The longitudinal succession of water characteristics in the White Nile: Hydrobiologia, v. 11, p. $73-89$

Tamm, C. O., 1953, Growth, yield and nutrition in carpets of a forest moss (Hylocomium splendens): Skogsforskn. Inst. Stockholm Medd., v. 43, no. 1, 140 p. 
Tamm, C. O., 1958, The atmosphere, p. 233-242 in Ruhland, W., Encyclopedia of plant physiology, v. 4: Berlin, Springer Verlag, $1210 \mathrm{p}$.

Tamm, C. O., and Troedsson, T., 1955, An example of the amounts of plant nutrients supplied to the ground in road dust: Oikos, v. 6, p. 61-70

- 1957, A new method for the study of water movement in soil: Geol. Fören. Stockholm Förh., v. 79 , p. $581-587$

Thompson, T. G., and Nelson, K. H., 1956, Concentration of brines and deposition of salts from sea water under frigid conditions: Am. Jour. Sci., v. 254, p. 227-238

Thresh, J. C., Beale, J. F., Suckling, E. V., and Taylor, E. W., 1949, Examination of waters and water supplies, 6 th ed.: Philadelphia, Blakiston, $819 \mathrm{p}$.

Troedsson, T., 1952, Den geologiska miljöns inverkan pa grundvattnets halt av lösta växtnaringsämnen: Kungl. Skogshögskolans Skr., no. 10, 16 p.

- 1955, Vattnet i skogsmarken: Kungl. Skogshögskolans Skr., no. 20, 215 p.

Turner, J. C., 1955, The salinity of rainfall as a function of drop size: Royal Meteorol. Soc. Quart. Jour., v. 81 , p. $418-429$

Twomey, S., 1953, The identification of individual hygroscopic particles in the atmosphere by a phasetransition method: Jour. Applied Physics, v. 24, p. 1099-1102

- 1954, The composition of hygroscopic particles in the atmosphere: Jour. Meteorology, v. 11, p. 334338

- 1955, The distribution of sea salt nuclei in air over land: Jour. Meteorology, v. 12, p. 81-86

1959, The nuclei of natural cloud formation: Geofisica Pura e Applicata, v. 43, p. 227-242

Twomey, S., and McMaster, K. N., 1955, The production of condensation nuclei by crystallizing salt particles: Tellus, v. 7 , p. $458-461$

Viro, P. J., 1953, Loss of nutrients and the natural nutrient balance of the soil in Finland: Inst. Forest. Fenniae Commun., v. 42, no. 1,51 p.

— 1955, Investigations on forest litter: Inst. Forest. Fenniae Commun., v. 45, no. 6, 65 p.

Welch, P. S., 1935, Limnology: New York, McGraw-Hill, 471 p.

Went, F. W., 1960, Organic matter in the atmosphere and its possible relation to petroleum formation: Nat. Acad. Sci. Proc., v. 46, p. 212-221

Wiklander, L., and Hallgren, G., 1949, Studies on gyttja soils I. Distribution of different sulfur and phosphorus forms and of iron, manganese and calcium carbonate in a profile from Kungsängen: Kungl. Lantbrukshögsk. Ann., v. 16, p. 811-827

Wiklander, L., Hallgren, G., and Jonsson, E., 1950, Studies on gyttja soils III. Rate of sulfur oxidation: Kungl. Lantbrukshögsk. Ann., v. 17, p. 425-440

Wiklander, L., Hallgren, G., Brink, N., and Jonsson, E., 1950, Studies on gyttja soils II. Some characteristics of two profiles from northern Sweden: Kungl. Lantbrukshögsk. Ann., v. 17, p. 24-36

Witting, M., 1947, Katjonbestämningar i myrvatten: Bot. Notiser Lund, p. 287-304

- 1948, Fortsatta katjonbestämningar i myrvatten sommaren 1947: Svensk Bot. Tidskr., v. 42, p. $116-134$

Wood, W. E., 1924, Increase of salt in soil and streams following the destruction of the native vegetation: Royal Soc. Western Australia Jour., v. 10, p. 35-47

Woodcock, A. H., 1952, Atmospheric salt particles and raindrops: Jour. Meteorology, v. 9, p. 200-212

- 1953, Salt nuclei in marine air as a function of altitude and wind force: Jour. Meteorology, v. 10, p. $362-371$

Woodcock, A. H., and Blanchard, D. C., 1955, Tests of the salt-nuclci hypothesis of rain formation: Tellus, v. 7, p. $437-448$

Woodcock, A. H., and Mordy, W. A., 1955, Salt nuclei, wind and daily rainfall in Hawaii: Tellus, v. 7, p. $291-300$

Woodcock, A. H., Kientzler, C. F., Arons, A. B., and Blanchard, D. C., 1953, Giant condensation nuclei from bursting bubbles: Nature, v. 172, p. 1144-1145

Wright, H. L., 1940, Atmospheric opacity at Valentia: Royal Meteorol. Soc. Quart. Jour., v. 66, p. 66-76

Yoshimura, S., 1936, The effect of salt-breeze on the chemical composition of freshwater lakes near the sea: Arch. Hydrobiologie, v. 30, p. 345-351

Manuscript Received by the Secretary of the Society, Janiary 28, 1960 